
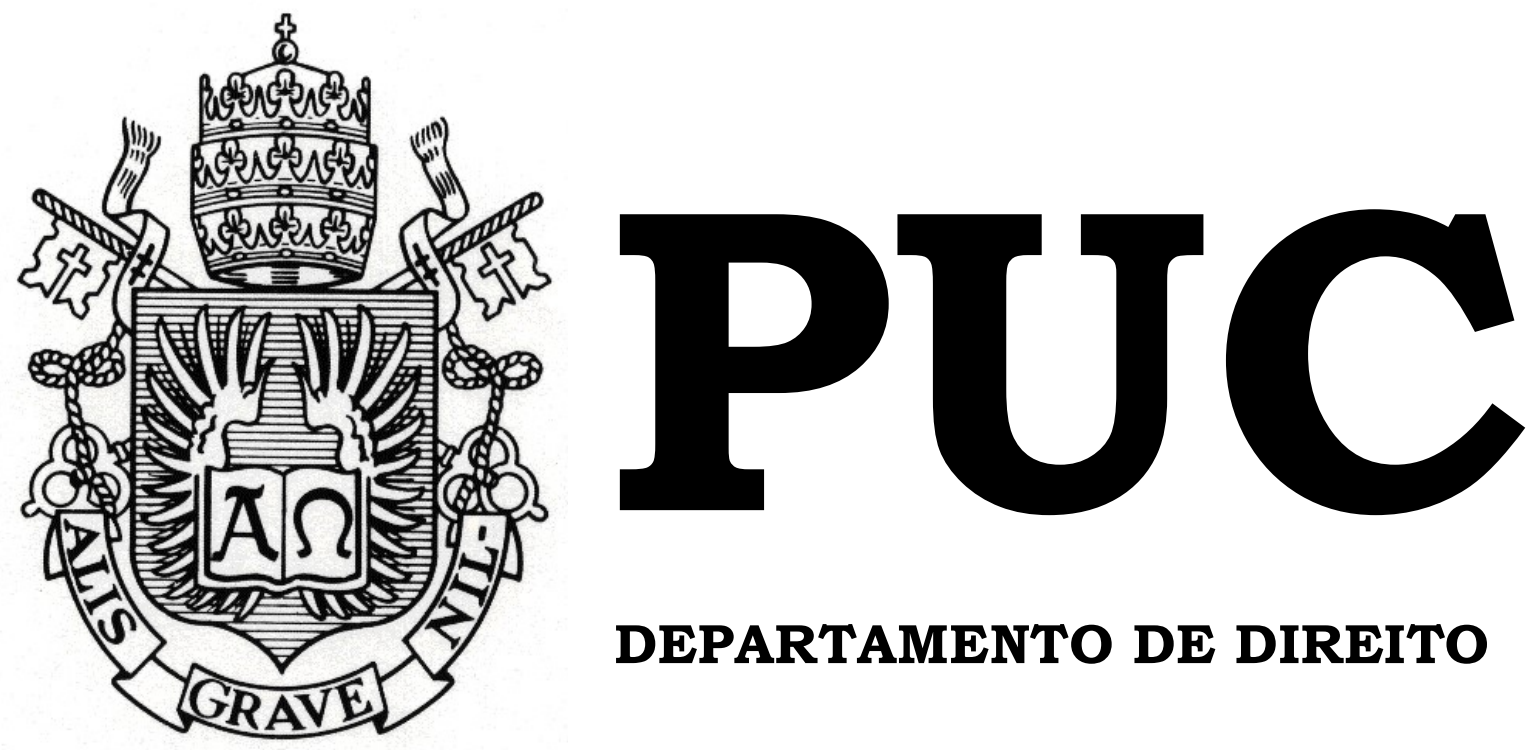

DEPARTAMENTO DE DIREITO

\title{
LIMITES AO ÓDIO: ANÁLISE DAS RESTRIÇÕES DA LIBERDADE DE EXPRESSÃO EM CASOS DE DISCURSO DE ÓDIO
}

Por

PAULA GUEDES FERNANDES DA SILVA

ORIENTADOR: Fábio Carvalho Leite

COORIENTADORA: Priscilla Regina da Silva 2018.1

PONTIFÍCIA UNIVERSIDADE CATÓLICA DO RIO DE JANEIRO

RUA MARQUÊS DE SÃO VICENTE, 225 - CEP 22451-900

RIO DE JANEIRO - BRASIL 


\title{
LIMITES AO ÓDIO: ANÁLISE DOS LIMITES DA LIBERDADE DE EXPRESSÃO EM CASOS DE DISCURSO DE ÓDIO
}

\author{
por \\ PAULA GUEDES FERNANDES DA SILVA
}

Monografia apresentada ao
Departamento de Direito da
Pontificia Universidade Católica do
Rio de Janeiro (PUC-Rio) para a
obtenção do Titulo de Bacharel em
Direito.

Orientador: Fábio Carvalho Leite Coorientadora: Priscilla Regina da

Silva

2018.1 


\section{AGRADECIMENTOS}

Nesta reta final do curso de Direito, sinto-me extremamente agradecida por todos aqueles que, de alguma forma, foram essenciais em minha trajetória, tornando-me mais confiante e determinada, na busca de sempre dar-lhes orgulho e inspiração.

Primeiramente, agradeço aos meus pais, Paulo Renato e Alba Valeria, pelo apoio e amor infinito em todos os momentos da minha vida, por serem os modelos que eu busco seguir e por nunca terem deixado de acreditar nos meus sonhos. Espero ser capaz de, algum dia, conseguir expressar adequadamente o tamanho do amor e agradecimento incondicionais que nutro por vocês. E aos meus irmãos, Daniel e Gabriel, sempre meus fiéis escudeiros, por todas as conversas, puxões de orelha, amor e carinho compartilhados.

Ao Daniel Davy, mein Schatz, por todo amor, companheirismo e carinho meu porto seguro e minha paz. Nunca terei palavras suficientes para agradecê-lo por todos os sorrisos sinceros, por todo apoio e presença reconfortante. Você torna minha vida mais leve e me inspira a lutar diariamente pelos meus sonhos. Cada dia que passa, meu amor e admiração por você só aumentam.

À minha família, em especial, aos meus avós, Paulo, Lizete, Sônia e Elbo, e tios, por, mesmo não compartilhando a rotina, estarem sempre presentes em minhas lutas e conquistas.

Às minhas melhores amigas, Ana Carolina e Laurence, pelos mais de dez anos de amizade verdadeira, tenho orgulho de saber que vocês são as irmãs que a vida me deu. 
Aos meus amigos de vida, especialmente, Klein, Vivacqua e Lobatinho, e aos amigos de escola, Raissa, Brenda, Montinha, Mimi e Arthur, por me ensinarem que não devo levar a vida tão à sério, proporcionando-me momentos de descontração e felicidade a cada encontro.

Às minhas amigas da PUC, Isabela, Laís, Thainá, Bia e Luiza, meus presentes da faculdade - responsáveis pela alegria de encontrar pessoas tão especiais, inesperadamente, ao final do curso. Vocês traziam leveza aos meus dias. Tenho certeza que levaremos essa amizade para muito além do Direito.

Aos meus sogros, Eduardo e Kátia, e minha cunhada, May, por terem me acolhido com tanto carinho e por serem, sem dúvidas, a minha segunda família.

À Sebastiana, por estar sempre cuidando de mim e por me surpreender todos os dias com suas habilidades culinárias. Sou extremamente grata por tudo.

À Yume, meu sonho bom, minha companheira que me ensinou o significado de amor em sua forma mais pura. A saudade é eterna, mas tenho certeza que você, de onde estiver, continua sendo meu anjinho protetor. Sua luz vai estar sempre comigo.

À Pontifícia Universidade Católica do Rio de Janeiro (PUC-RJ) e aos professores do curso de Direito, por me abrirem os olhos para as questões sociais do mundo e por nutrirem o meu amor pelos Direitos Humanos e pela luta por um mundo mais justo. Agradecimento especial para a professora Ana Paula Santoro, por todo o apoio e por me ensinar que o medo faz parte da trajetória dos sonhos - e que somos muito maiores do que ele.

À Miriam, minha querida amiga alemã, por, mesmo distante, me ajudar na busca por textos jurídicos e bibliografia dentro do contexto de seu país incrível. Danke schön. 
Por último, mas não menos importante, agradecer ao meu orientador, professor Fábio Leite, e à minha coorientadora, Priscilla Regina da Silva, por todo o aprendizado, sugestões e conselhos durante a realização deste trabalho. Vocês, com certeza, foram fonte de inspiração por serem excepcionais dentro de suas áreas de pesquisa e atuação. Agradeço pela confiança, paciência e oportunidade de aprender com vocês. 


\section{RESUMO}

SILVA, Paula Guedes Fernandes da. Limites ao Ódio: Análise dos Limites da Liberdade de Expressão em Casos de Discurso de Ódio. Rio de Janeiro: 2018: 120 p. Monografia de final de curso. Departamento de Direito da Pontifícia Universidade Católica do Rio de Janeiro - PUC-Rio.

A Liberdade de Expressão é internacionalmente reconhecida como um direito fundamental essencial, considerada, ao nível pessoal, a chave para o desenvolvimento, dignidade e realização das pessoas e, ao nível estatal, vital para o crescimento da democracia e o progresso social, pois assegura a prestação de contas do Estado e o livre debate de ideias. Entretanto, esta constatação é posta em dúvida quando o direito é utilizado para difusão de ideias odiosas, aptas a incitar a violência concreta contra determinados grupos. A partir da constatação de que certos discursos são tão danosos para a coletividade que devem ser proibidos, o grande desafio do presente trabalho é entender até que ponto o discurso de ódio pode ser visto como um balizador para a Liberdade de Expressão. Amparado na análise da doutrina e jurisprudência internacional, a favor e contra a limitação deste direito fundamental frente ao hate speech, e dos standards internacionais, objetivam-se estipular parâmetros judiciais, legislativos e políticos de possível aplicação no cenário brasileiro, onde não há, ainda, tratamento específico sobre a questão.

Palavras-Chave: discurso de ódio; hate speech; dignidade da pessoa; igualdade; liberdade de opinião; liberdade de expressão. 


\section{Abstract}

Freedom of Speech is internationally recognized as an essential fundamental right, considered, at personal level, the key to development, dignity and self-satisfaction and, at State level, vital for the democratic growth and social progress, as it ensures the accountability of the State and the free debate of ideas. However, doubt is cast on this observation when this right is used to spread hateful ideas, capable of inciting concrete violence against certain groups. Based on the fact that some speech are extremely harmful to the community that they should be prohibited, the biggest challenge of this paper is to understand the extent to which hate speech could be seen as a marker for freedom of expression. From the analysis of foreign doctrine and jurisprudence, for and against the limitation of this fundamental right, in opposition to hate speech, and of international standards, the main aim of this paper is to stipulate judicial, legislative and political criteria of possible application in the Brazilian situation, where there is not yet a specific treatment on this issue.

Keywords: hate speech; human dignity; equality; freedom of opinion; freedom of speech. 


\section{Zusammenfassung}

Die Redefreiheit gilt international als ein notwendiges Grundrecht, das auf persönlicher Ebene als essentiell für die Entwicklung, Würde und Selbstverwirklichung des Menschens betrachtet wird und, auf staatlicher Ebene, unerlässlich für das Wachstum der Demokratie und den sozialen Fortschritt, weil es die staatliche Rechenschaftspflicht und den freien Gedankenaustausch gewährleistet. Allerdings wird diese Feststellung in Frage gestellt, wenn das Recht zur Verbreitung von Hassrede missbraucht wird, die zu konkreter Gewalt gegen bestimmte Gruppen aufrufen. Die Tatsache, dass bestimmte Äusserungen für die Gemeinschaft so schädlich sind, dass sie verboten werden sollten, liegt die große Herausforderung dieser Bachelorarbeit darin, zu verstehen, inwieweit Hassreden als Grenze für die Redefreiheit angesehen werden können. Basierend auf der Auswertung der Rechtslehre und der internationalen Rechtswissenschaft, zugunsten und gegen die Beschränkung dieses Grundrechts angesichts von Hassreden, und der internationalen Standards, sollen gerichtliche, gesetzgebende und politische Kriterien der möglichen Anwendung im brasilianischen Zusammenhang festgelegt werden, wo es bislang noch keine spezifische Behandlung des Problems gibt.

Schlüsselwörter: Hassrede; Menschenwürde; Gleichberechtigung; freie Meinungsäußerung; Redefreiheit. 


\section{SUMÁRIO}

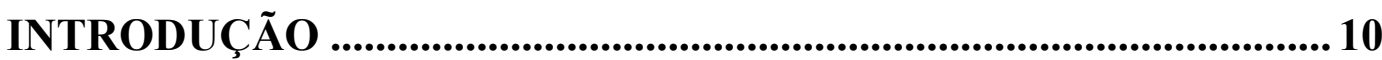

CAPÍTULO 1 - Discussão doutrinária a respeito do provável embate entre liberdade de expressão e discurso de ódio.......................................... 12

1.1 Fundamentos e importância da liberdade de expressão ...................... 13

1.1.1 Mercado livre de ideias na busca da verdade .................................. 15

1.1.2 Manutenção do regime democrático …………………………….... 17

1.1.3 Autossatisfação individual........................................................... 18

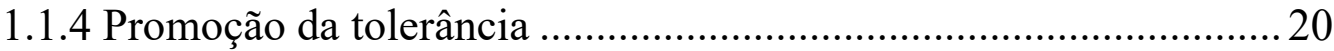

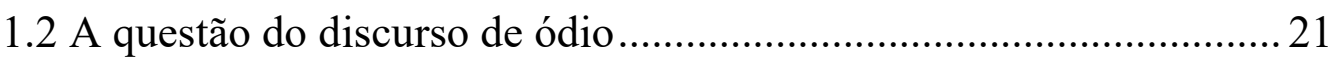

1.2.1 Fundamentos da proteção ao discurso de ódio - liberdade de

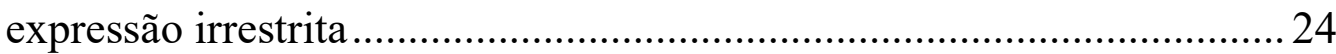

1.2.1 Fundamentos da repressão ao discurso de ódio - limites à liberdade

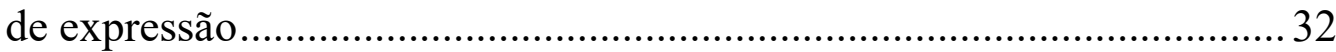

CAPÍTULO 2 - Parâmetros internacionais: possibilidade ou não de restriçãa aos discursos odiosos ............................................................................... 42

2.1 Sistema americano de proteção ao discurso de ódio ............................ 42

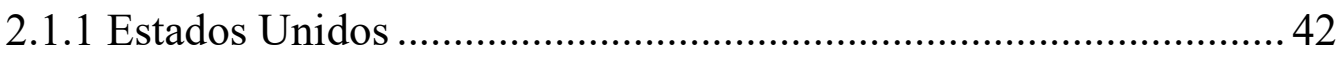

2.1.2 Sistema Interamericano de Direitos Humanos ................................55

2.2 Sistema europeu de combate ao discurso de ódio ..............................58

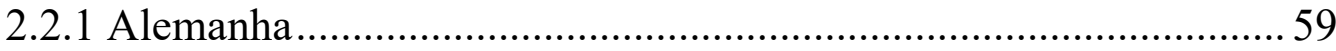

2.2.2 O Sistema Europeu de Direitos Humanos ........................................ 71

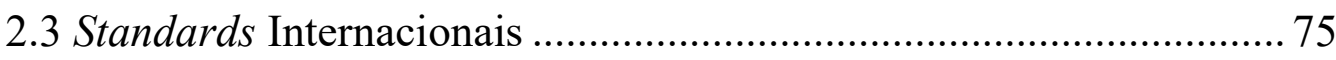

CAPÍTULO 3 - O embate entre liberdade de expressão e discurso de ódio no Brasil ................................................................................................................ 81

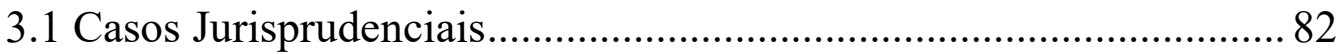

3.2 Entendimentos retirados do cenário brasileiro atual .......................... 91 
3.3 Aplicação dos standards internacionais no contexto brasileiro .........99

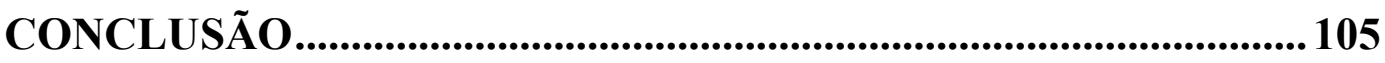

REFERÊNCIAS BIBLIOGRÁFICAS ................................................. 109 


\section{INTRODUÇÃO}

Quando falamos de liberdade de expressão não há quem discorde de que é um direito humano fundamental, essencial não só para o desenvolvimento de uma sociedade plural, onde a livre troca de ideias é assegurada, mas também para a preservação do funcionamento das democracias modernas. ${ }^{1}$ No entanto, esta constatação é posta em dúvida quando este direito é utilizado como difusor de ideias odiosas, desprezíveis e ofensivas, que fomentam a discriminação, o preconceito e a prática de atos violentos contra determinados grupos ou segmentos da sociedade, através do que chamam de "discurso de ódio" ou "hate speech".

Por esta perspectiva, a problemática atual é a de estabelecer limites à liberdade de expressão e até onde estes poderiam ser realizados, sem prejuízo efetivo a este direito fundamental e sem ignorar a fragilidade e complexidade do tema, visto que a incitação ao ódio pode ser escalonada até a concretização de atos de intolerância e violência, como ocorrido durante o Holocausto nazista, com o genocídio de mais de 6 milhões judeus, ou, recentemente, com a morte de uma mulher e dezenas de feridos em um movimento neonazista organizado, principalmente, por supremacistas brancos em Charlottesville, nos Estados Unidos. ${ }^{2}$

De forma a introduzir o estudo desta problemática, o primeiro capítulo deste trabalho fará a análise da liberdade de expressão com base em seus fundamentos essenciais - a busca pela verdade, a manutenção do regime democrático, a efetivação da autossatisfação individual e a promoção da tolerância. Em seguida, a discussão será direcionada para o discurso de ódio, a partir da avaliação de argumentos doutrinários em

\footnotetext{
${ }^{1}$ NEXO. Quando é justificável proibir um discurso, segundo esta ONG. 28 de agosto de 2017. Disponível em: <https://www.nexojornal.com.br/entrevista/2017/08/22/Quando-\%C3\%A9justific\%C3\%A1 vel-proibir-um-discurso-segundo-esta-ONG>. Acesso em: 02 abr. 2018.

${ }^{2}$ O Globo. EUA: Carro avança contra protesto antirracismo e deixa um morto. 12 de agosto de 2017. Disponível em <https://oglobo.globo.com/mundo/eua-carro-avanca-contra-protestoantirracismo-deixa-um-morto-1-21699532>. Acesso em: 19 abr. 2018.
} 
relação à proteção ou não de manifestações deste gênero, que configurem preconceito, intolerância e incitamento ao ódio e a violência contra determinado grupo, especialmente minorias historicamente discriminadas.

O segundo capítulo trará a abordagem contraposta dada ao discurso de ódio em sistemas internacionais, assim como no direito comparado, através da apreciação de entendimentos retirados da doutrina e jurisprudência. De um lado, há quem garanta maior proteção à liberdade de expressão, por meio da concepção de que esta não deve apenas proteger ideias moralmente aceitas pela sociedade, mas também discursos que desprezamos, repletos de preconceito, segregação e discriminação. De outro, estão os defensores de que as expressões de ódio e intolerância não devem receber a proteção da liberdade de expressão, uma vez que atuam como violadores de direitos, especialmente a igualdade e a dignidade das vítimas. No tópico final deste capítulo ainda trarei standards internacionais que funcionam como parâmetros para a solução da controvérsia, sendo sua aplicação nos ordenamentos internos recomendada pelos organismos de Direito Internacional dos Direitos Humanos.

Por fim, o terceiro e último capítulo é direcionado à análise do contexto brasileiro em relação à liberdade de expressão e ao hate speech. Essa avaliação será a partir da leitura crítica da realidade social e dos entendimentos retirados de casos concretos nacionais para, enfim, realizar a tentativa de aplicação dos standards internacionais de forma adaptada ao contexto do Brasil, visando a criação de padrões legislativos, judiciais e políticos a serem utilizados nos casos de discurso de ódio. 


\section{CAPÍTULO 1 - DISCUSSÃO DOUTRINÁRIA A RESPEITO DO PROVÁVEL EMBATE ENTRE LIBERDADE DE EXPRESSÃO E DISCURSO DE ÓDIO}

A liberdade de expressão é protegida como direito fundamental na maioria dos ordenamentos jurídicos nacionais e em tratados internacionais sobre direitos humanos da atualidade, considerada um dos fundamentos do Estado Democrático de Direito. ${ }^{3}$ Ao lado do direito à igualdade, a liberdade de expressão tem papel essencial na garantia da democracia e no desenvolvimento humano sustentável, além de promover paz e segurança internacional. ${ }^{4}$

Em perspectiva individual, o direito à expressão fundamenta-se na possibilidade de construção das dignidades dos sujeitos, considerada requisito essencial da própria condição humana, viabilizando sua autorrealização. Coletivamente, esse direito desempenha um papel constitutivo das sociedades liberais e democráticas, possibilitando a livre circulação de ideias, para que seus integrantes escolham aquelas que mais parecem adequadas. A liberdade de expressão é, igualmente, basilar até para que haja possibilidade de discussão sobre a permissão ou não de externar ideias, opiniões e crenças nocivas a outrem. ${ }^{5}$

Não há, na atualidade, dúvidas a respeito da importância da garantia à liberdade de expressão. Vivemos, porém, em contexto de incertezas quanto aos seus limites, necessários, excepcionalmente, para que outras garantias fundamentais possam ser igualmente protegidas, como os direitos

\footnotetext{
${ }^{3}$ Para Luís Roberto Barroso, o Estado Democrático de Direito envolve quem decide (fonte do poder), como decide (procedimento adequado) e $o$ que pode e o que não pode ser decidido (conteúdo das obrigações negativas e positivas dos órgãos de poder). BARROSO, Luís Roberto. Curso de Direito Constitucional Contemporâneo: os conceitos fundamentais e a construção do novo modelo. $4^{\mathrm{a}}$ ed. São Paulo: Saraiva, 2013. p. 63.

${ }^{4}$ Article 19. The Camden Principles on Freedom of Expression and Equality. Disponível em $<$ https://www.article19.org/data/files/pdfs/standards/the-camden-principles-on-freedom-ofexpression-and-equality.pdf $>$. Acesso em: 16 out. 2017.

${ }^{5}$ CHEQUER, Cláudio. A Liberdade de Expressão como Direito Fundamental Preferencial Prima Facie: (análise crítica e proposta de revisão ao padrão jurisprudencial brasileiro). Rio de Janeiro: Lumen Juris, 2011. p. 1-4.
} 
da personalidade, por exemplo. Embora seja prevista como direito fundamental, a liberdade de expressão é considerada, para alguns doutrinadores, como não absoluta, esbarrando em questões como o discurso de ódio - sobre a proteção ou não de manifestações de ódio, desprezo ou intolerância a determinados grupos sociais, especialmente minorias, por razões diversas, como raça, gênero, religião ou etnia. ${ }^{6}$

Diante de tais problemas, o presente capítulo busca entender os limites da liberdade de expressão, através da problemática dos discursos odiosos. Veremos que alguns doutrinadores defendem a ideia de que liberdade de expressão não pode servir simplesmente para a proteção de pressupostos e opiniões eticamente corretos ou moralmente aceitos pela maioria da sociedade, mas também aqueles discursos e ideias desprezíveis e detestáveis, inclusive aquelas que odiamos. ${ }^{7}$ Demais doutrinadores, por outro lado, acreditam que manifestações de ódio não devem ser aceitas, uma vez que seriam capazes de violar direitos e garantias fundamentais das vítimas.

\subsection{Fundamentos e importância da liberdade de expressão}

É inata ao homem a vontade e necessidade de exposição de ideias, opiniões, sentimentos e sensações, de forma que, ainda que em períodos de governos opressores e totalitários, o direito de expressar-se e expor ideias assim como o de opor-se às opiniões predominantes -, sempre encontraram uma forma de manifestação, implícita ou explicitamente. ${ }^{8}$

A liberdade de expressão é tida como fruto do período iluminista, considerada um direito fundamental de primeira geração, tendo como

\footnotetext{
${ }^{6}$ SARMENTO, Daniel. A Liberdade de Expressão e o Problema do Hate Speech. Rio de Janeiro, 2006. Disponível em <http://www.dsarmento.adv.br/content/3-publicacoes/18-a-liberdade-deexpressao-e-o-problema-do-hate-speech/a-liberdade-de-expressao-e-o-problema-do-hate-speechdaniel-sarmento.pdf>. Acesso em: 16 out. 2017.

${ }^{7}$ LEWIS, Anthony. Liberdade Para as Ideias que Odiamos: Uma Biografia da Primeira Emenda à Constituição Americana. São Paulo: Aracati, 2011. p.54.

${ }^{8}$ MEYER-PFLUG, Samantha Ribeiro. Liberdade de Expressão e Discurso do Ódio. São Paulo: RT, 2009. p.69-70.
} 
marco característico a oposição ao poder estatal. Atualmente, porém, este direito não se limita apenas a esta função. A Declaração Universal dos Direitos do Homem (artigo 19) estabeleceu o direito de todos à liberdade de opinião e expressão, o que inclui a liberdade de ter opiniões e de procurar, receber e transmitir informações e ideias por quaisquer meios e independentemente de fronteiras, sem interferências. ${ }^{9}$

Desta forma, o direito do indivíduo de receber informações e a escolha de ideias que lhe parecem adequadas, além da consequente discussão com demais membros da sociedade e o direito de questionar um sistema que considera injusto são elementos da liberdade de expressão, protegida por duas dimensões distintas: negativa e positiva. Em seu viés negativo, a liberdade de expressão se refere à obrigação do Estado de não frear a expressão da personalidade do homem, sendo obrigatório o agir de forma neutra frente às opiniões, de maneira que a liberdade de manifestação do pensamento ocorra livremente - obrigação de não fazer do ente estatal, permitindo a expressão e desenvolvimento da personalidade do homem de forma integral. Além disso, a liberdade de expressão, em seu viés positivo, exige que o Estado atue no incentivo ao debate público democrático, com participação de diversos setores da sociedade e dando condições mínimas para sua existência, de forma a consolidar o princípio democrático. ${ }^{10}$

Nesse sentido, a doutrina utiliza-se de argumentos para respaldar a liberdade de expressão como um direito fundamental, além de traçar objetivos associados a ela: (i) busca e a descoberta da verdade; (ii) participação do indivíduo na democracia, de forma a garanti-la; (iii)

\footnotetext{
${ }^{9}$ Texto original: "Everyone has the right to freedom of opinion and expression; this right includes freedom to hold opinions without interference and to seek, receive and impart information and ideas through any media and regardless of frontiers." ONU. Universal Declaration of Human Rights. Disponível

em $<$ http://www.ohchr.org/EN/UDHR/Documents/UDHR_Translations/eng.pdf $>$. Acesso em: 16 out. 2017.

${ }^{10}$ MEYER-PFLUG, Samantha Ribeiro. Liberdade de expressão e discurso do ódio. São Paulo: RT, 2009. p.69-77
} 
garantia da autossatisfação (autorrealização) individual do homem; (iv) promoção da tolerância entre os membros da sociedade. ${ }^{11}$

A seguir, analisarei a teoria do mercado livre de ideias, especialmente sob o viés de John Stuart Mill, na busca da verdade, passando para o debate sobre a legitimidade do processo democrático através da ampla liberdade de expressão, além de traçar pontos da importância deste direito fundamental à autorrealização individual e à promoção da tolerância. Posteriormente, passarei para a análise do discurso de ódio como limite à expressão, associando os objetivos e fundamentos da liberdade de expressão com a regulação dos discursos odiosos.

\subsubsection{Mercado livre de ideias na busca da verdade}

John Stuart Mill foi um filósofo e economista inglês, considerado precursor da teoria do livre mercado de ideias (marketplace of ideas) ${ }^{12}$. Para Mill, o exercício pleno da liberdade de expressão seria essencial para alcançar a verdade. Sua teoria girava em torno de três pressupostos: primeiramente, a constatação de que o homem não é infalível, ${ }^{13}$ suscetível ao entendimento de que sua concepção de verdade é falaciosa - logo, a proibição de ideias e opiniões pelos governos ou maiorias é entendida, pelo

\footnotetext{
${ }^{11}$ CHEQUER, Cláudio. A Liberdade de Expressão como Direito Fundamental Preferencial Prima Facie: (análise crítica e proposta de revisão ao padrão jurisprudencial brasileiro). Rio de Janeiro: Lumen Juris, 2011. p. 17-18; SARMENTO, Daniel. A Liberdade de Expressão e o Problema do Hate Speech. Rio de Janeiro, 2006. Disponível em <http://www.dsarmento.adv.br/content/3publicacoes/18-a-liberdade-de-expressao-e-o-problema-do-hate-speech/a-liberdade-de-expressaoe-o-problema-do-hate-speech-daniel-sarmento.pdf $>$. Acesso em: 16 out. 2017.

${ }^{12} \mathrm{O}$ termo "mercado livre de ideias" surgiu no julgamento do caso Abrams vs. Unimted States pela Suprema Corte dos Estados Unidos, especificamente no voto dissidente do Oliver Wendell, ao fazer sua interpretação sobre a teoria de John Stuart Mill. CHEQUER, Cláudio. A Liberdade de Expressão como Direito Fundamental Preferencial Prima Facie: (análise crítica e proposta de revisão ao padrão jurisprudencial brasileiro). Rio de Janeiro: Lumen Juris, 2011. p. 17-18; LEWIS, Anthony. Liberdade Para as Ideias que Odiamos: Uma Biografia da Primeira Emenda à Constituição Americana. São Paulo: Aracati, 2011. p.48-49.

13 "First: the opinion which it is attempted to suppress by authority may possibly be true. Those who desire to suppress it, of course deny its truth; but they are not infallible. They have no authority to decide the question for all mankind, and exclude every other person from the means of judging. To refuse a hearing to an opinion, because they are sure that it is false, is to assume that their certainty is the same thing as absolute certainty. All silencing of discussion is an assumption of infallibility. Its condemnation may be allowed to rest on this common argument, not the worse for being common.”. MILL, John Stuart. On Liberty (1859). Kitchener: Batoche Books, 2001. p. 18-52.
} 
autor, como um desacerto, pois ideias que falseiam a verdade, para a maioria ou senso comum, podem ser verdadeiras e, mesmo não o sendo, poderiam possuir resquícios de verdade. Além disso, para o filósofo, mesmo que nossas crenças sejam verdadeiras, não temos como saber a razão de serem verdadeiras se não forem contrastadas com críticas de quem discorda de nós, uma vez que o confronto de ideias fortalece aquelas que são verídicas. Destaca o filósofo que nossas crenças e as crenças de quem discorda de nós possuem uma parcela de verdade, por isso, é fundamental que ambos os lados se expressem e sejam conhecidos. Nesse sentido, para Mill, a raça humana é roubada quando se executa o mal de silenciar a expressão de uma opinião. ${ }^{14}$

John Stuart Mill utiliza de exemplificações, como Sócrates e o Imperador Marco Aurélio, para demonstrar os efeitos da supressão da liberdade de ideias pelo governo - Sócrates, por exemplo, foi morto, após condenação judicial, por seus similares, por ter ideias que estavam a frente de seu tempo, julgadas, à época, como imorais e impiedosas, ao negar os deuses que eram reconhecidos pelo Estado, atuando como "corruptor da juventude"15. Um dos homens mais citados e brilhantes da humanidade foi condenado a morte como um criminoso, através do erro de aceitar uma verdade como absoluta, sem que houvesse discussão e confronto das ideias em jogo.

Desta forma, a liberdade de expressão seria instrumento eficaz e de suma importância para a busca e obtenção da verdade. A liberdade de transmitir ideias e criticar visões de mundo pré-existentes é vital para que sejam tomadas melhores decisões, ${ }^{16}$ especialmente em se tratando de temas polêmicos e controvertidos, permitindo que o debate amplo e plural leve a melhores respostas. Nenhuma opinião, portanto, estaria ou deveria estar

\footnotetext{
${ }^{14}$ MILL, John Stuart. On Liberty (1859). Kitchener: Batoche Books, 2001. p. 19.

${ }^{15}$ Ibid. p. $25-26$.

${ }^{16}$ ALEXANDER, Larry. Is there a Right of Freedom of Expression? New York: Cambridge University Press, 2005. p.128.
} 
imune à crítica ou à negação, nem limitada por restrições impostas por grupos ou pelo Estado.

\subsubsection{Manutenção do regime democrático}

A liberdade de expressão é, como já dito, elemento essencial para qualquer regime que se pretenda democrático. Para Giovani Sartori, as eleições e o poder de eleger representantes é "per se uma garantia mecânica da democracia". ${ }^{17}$ A garantia essencial, substantiva, para a democracia é, portanto, constituída através das condições de acesso do cidadão às informações. Desta forma, a realização de eleições é pressuposto do Estado Democrático, mas também entendida como um meio para a finalidade de "governo de opinião". Portanto, uma democracia não se limita apenas a eleições livres - a liberdade de expressão constituiria uma garantia substancial da democracia, de forma a permitir que os indivíduos pudessem debater ideias, expor opiniões e criticar aquelas que não the parecem adequadas.

A liberdade de expressão é imprescindível para a existência de debates públicos, capazes de formar a opinião pública em um sistema democrático, permitindo que os cidadãos possam participar ativamente da agenda política - autogoverno. Nesse sentido, Ronald Dworkin entende que esse direito fundamental não é essencial apenas para a formação de um eleitorado consciente e preparado para a tomada de decisões, sendo também elemento vital de legitimação do processo democrático. Nas palavras do autor:

Uma democracia justa exige o que poderíamos chamar de um "fundo"18 democrático: exige, por exemplo, que todos os adultos competentes possuam voto para decidir qual é a vontade da maioria. Exige, além disso, que cada cidadão não tenha apenas um voto, mas uma voz: a decisão da maioria não é justa, a menos

\footnotetext{
17 SARTONI, Giovanni. A Teoria da Democracia Revisada: volume I - o debate contemporâneo. Tradução de Dinah de Abreu Azevedo. São Paulo: Editora Átila, 1994. p. 123-125.

18 Traduzido como "fundo" democrático no sentido de "base" e "fundamento", trazendo a ideia de uma base democrática.
} 
que todos tenham tido uma oportunidade justa de expressar suas atitudes ou opiniões ou medos ou gostos ou pressupostos ou preconceitos ou ideais, não apenas na esperança de influenciar os outros (embora essa esperança seja crucialmente importante), mas também para apenas confirmar a sua posição como agente responsável, em vez de uma vítima passiva, de uma ação coletiva. A maioria não tem o direito de impor sua vontade a alguém que é proibido de levantar voz em protesto ou debate ou objeção antes da decisão ser tomada. ${ }^{19}$ (Tradução livre)

Logo, o ideal democrático só é alcançável em um contexto de liberdade de ideias, em que os membros da sociedade têm a possibilidade e o direito de manifestação, além da abertura para receber conteúdos que estejam de acordo com suas convicções e até aqueles de que discorda.

\subsubsection{Autossatisfação individual}

Aristóteles, em sua obra sobre a política, já dizia que o homem é um ser sociável. ${ }^{20} \mathrm{~A}$ necessidade de exprimir ideias, sensações e opiniões é inata ao ser humano, sendo constitutiva de sua dignidade e autonomia individual.

Nesse sentido, para que o indivíduo desenvolva livremente a personalidade, de forma a eleger opções de vida e formar convicções próprias, é indispensável que lhe seja garantida a liberdade de expressão, para que tenha acesso às mais plurais informações e pontos de vista a respeito de determinada matéria. ${ }^{21}$ Uma pessoa não é considerada

\footnotetext{
${ }^{19}$ DWORKIN, Ronald. Foreword to Extreme Speech and Democracy. In.: HARE, Ivan; WEINSTEIN, James (editors). Extreme Speech and Democracy. New York: Oxford University Press, 2009. p. v-ix. Citação original: "Fair democracy requires what we might call a democratic background: it requires, for example, that every competent adult have a vote in deciding what the majority's will is And it requires, further, that each citizen have not just a vote but a voice: a majority decision is not fair unless everyone has had a fair opportunity to express his or her attitudes or opinions or fears or tastes or presuppositions or prejudices or ideals, not just in the hope of influencing others (though that hope is crucially important), but also just to confirm his or her standing as a responsible agent in, rather than a passive victim of, collective action. The majority has no right to impose its will on someone who is forbidden to raise a voice in protest or argument or objection before the decision is taken."

${ }^{20}$ ARISTÓTELES. Política. Tradução de Maria da Gama Kury. 3. ed. Brasília: Editora UnB, 1997.

${ }^{21}$ SARMENTO, Daniel. A Liberdade de Expressão e o Problema do Hate Speech. Rio de Janeiro, 2006. Disponível em <http://www.dsarmento.adv.br/content/3-publicacoes/18-a-liberdade-deexpressao-e-o-problema-do-hate-speech/a-liberdade-de-expressao-e-o-problema-do-hate-speechdaniel-sarmento.pdf $>$. Acesso em: 17 out. 2017.
} 
formalmente autônoma se a lei lhe nega o direito de usar suas próprias opiniões e expressões para encarnar suas visões de mundo. ${ }^{22}$ É nesse contexto que Ronald Dworkin assume que o Estado tem o dever de tratar seus cidadãos adultos, com exceção daqueles considerados incapazes pela lei vigente, como agentes morais responsáveis - sendo essa responsabilidade moral traço vital e constitutivo de sociedade política justa. Nesse cenário, pessoas responsáveis são aptas a tomar suas próprias decisões do que é bom ou ruim para suas vidas e no que entendem como política e, ademais, o que seria considerado verdadeiro ou não no que tange à justiça e à fé. ${ }^{23}$

Pode-se alegar, nesse sentido, que o Estado estaria insultando seus cidadãos e negando-lhes a responsabilidade moral por suas escolhas quando decreta que não se pode confiar neles para discernir opiniões e ouvir aquelas que possam persuadi-los a adotar convicções perigosas ou ofensivas a outrem. ${ }^{24}$ A liberdade de expressão é, pois, meio essencial para a realização da autonomia individual do homem e promoção da sua personalidade, especialmente em cenários de democracia, em que o povo é capaz de governar-se a si mesmo através de seu próprio julgamento. ${ }^{25}$

Dworkin defende também que o indivíduo só é considerado apto a conservar sua dignidade individual quando insiste no fato de que ninguém, nem o governo nem a maioria dos cidadãos, tem o direito de impedi-lo de ouvir uma opinião por ter medo de que este não esteja apto a ouvi-la e ponderá-la. ${ }^{26}$ Portanto, o homem possui responsabilidade moral própria de não só constituir convicções próprias, mas também expressá-las para os

\footnotetext{
${ }^{22}$ BAKER, C. Edwin. Hate Speech. Faculty Scholarship. Paper 198, 2008. p. 4.

${ }^{23}$ DWORKIN, Ronald. Por que a liberdade de Expressão. In: O Direito da Liberdade: A Leitura Moral da Constituição Norte-Americana. São Paulo: Martins Fontes Editora, 2006. p.319.

${ }^{24}$ Ibid. p.318-320.

${ }^{25}$ WALDRON, Jeremy. Precommitment and Disagreement. In: ALEXANDER, Larry (editor). Constitutionalism: Philosophical Foundations. Cambridge: Cambridge University Press, 1998. p. 280-281.

${ }^{26}$ DWORKIN, Ronald. Por que a Liberdade de Expressão. In: O Direito da Liberdade: A Leitura Moral da Constituição Norte-Americana. São Paulo: Martins Fontes Editora, 2006. p. 319.
} 
outros, estando movido pelo respeito para com seus semelhantes e pelo desejo de que o "bem triunfe". ${ }^{27}$

\subsubsection{Promoção da tolerância}

A tolerância é virtude fundamental em sociedades com grande desacordo moral, onde é comum que cidadãos não concordem com premissas levantadas por outros, sendo, portanto, de extrema importância como garantia de estabilidade e promoção de um contexto mais justo. ${ }^{28}$ Aceitar ideias alheias seria respeitar os indivíduos em suas diferenças, de forma a permitir que cada um viva à sua maneira, especialmente no cenário atual de pluralismo e diversidade cultural, ética e religiosa. ${ }^{29}$

A liberdade de expressão é uma das formas de promoção de um contexto social mais tolerante, através da ideia de que cada indivíduo possui o direito de expressar suas ideias e, portanto, deve tolerar o outro no exercício deste mesmo direito. Anthony Lewis defende que uma sociedade deve ter a coragem de estar apta a ouvir não só o discurso político indesejável, mas também ideias recentes e chocantes que nos chegam por meio da ciência e das artes. ${ }^{30}$

Através do direito à livre manifestação de ideias e pensamentos, o homem torna-se obrigado a tolerar o grande número de ideias disponíveis, exercitando sua capacidade de autocontrole em aceitar inclusive aquelas que considera inaceitáveis e até desprezíveis. ${ }^{31}$ Desta forma, o homem

\footnotetext{
${ }^{27}$ Ibid. p.320.

${ }^{28}$ SARMENTO, Daniel. A Liberdade de Expressão e o Problema do Hate Speech. Rio de Janeiro, 2006. Disponível em <http://www.dsarmento.adv.br/content/3-publicacoes/18-a-liberdade-deexpressao-e-o-problema-do-hate-speech/a-liberdade-de-expressao-e-o-problema-do-hate-speechdaniel-sarmento.pdf>. Acesso em: 17 out. 2017.

29 Ibid. Disponível em <http://www.dsarmento.adv.br/content/3-publicacoes/18-a-liberdade-deexpressao-e-o-problema-do-hate-speech/a-liberdade-de-expressao-e-o-problema-do-hate-speechdaniel-sarmento.pdf>. 17 out. 2017.

${ }^{30}$ LEWIS, Anthony. Liberdade Para as Ideias que Odiamos: Uma Biografia da Primeira Emenda à Constituição Americana. São Paulo: Aracati, 2011. p.54.

${ }^{31}$ BOLLINGER, Leo C. The Tolerant Society: Freedom of Expression and Extremist Speech in America. New York: Oxford University Press, 1986. p. 120-124.
} 
tornar-se-ia mais flexível diante das diversidades e pluralismo presentes na sociedade, especialmente no mundo contemporâneo.

Destarte, a liberdade de expressão pode ser vista como meio de promoção da tolerância das mais variadas formas de ideias, de maneira a possibilitar que as premissas e opiniões não adequadas sejam descartadas através da discussão pública dos assuntos de interesse público e de autocontrole individual do homem de aceitar ideias de terceiros, cada qual com suas peculiaridades e convicções próprias. ${ }^{32}$

\subsection{A questão do discurso de ódio}

Como visto na parte inicial do presente capítulo, a liberdade de expressão constitui direito intrínseco a todas as sociedades democráticas, estando, praticamente, na integralidade dos ordenamentos jurídicos mundiais e documentos internacionais, porém, apesar da unanimidade em relação a sua relevância e indispensabilidade, este direito vem enfrentando problemáticas em relação aos seus limites, sendo o discurso de ódio um dos vieses dessa questão.

O conceito de discurso de ódio mais utilizado pela doutrina é aquele definido por Michel Rosenfeld como sendo o discurso (fala) destinado a promover o ódio com base em raça, religião, etnia ou origem nacional (nacionalidade). ${ }^{33}$ Todavia, diante das complexidades das comunidades e sociedades contemporâneas, tal definição, apesar de ampla, torna-se problemática por não definir, em seus contornos, todas as hipóteses de bases de sustentação para o discurso odioso, vindo a deixar possíveis

\footnotetext{
${ }^{32}$ Neste ponto é relevante mencionar o Paradoxo da Tolerância, desenvolvido por Karl Popper, a ser analisado no ponto 1.2.1, para que possamos refletir até que ponto devemos tolerar ideias consideradas como intolerantes, como o discurso de ódio, sem que haja a destruição da própria tolerância.

${ }^{33}$ ROSENFELD, Michel. Hate Speech in Constitutional Jurisprudence: A Comparative Analysis. Cardozo Law Review. New York: Working Paper Series No. 41, 2001. Disponível em: http://papers.ssrn.com/sol3/papers.cfm?abstract_id=265939>. Acesso em: 17 out. 2017. Citação Original: "Hate speech -- that is, speech designed to promote hatred on the basis of race, religion, ethnicity or national origin (...).”
} 
vítimas de fora do conceito estabelecido. Desta forma, para o presente trabalho, se inclui nesta definição também os discursos odiosos proferidos com base em deficiência física, orientação sexual, gênero e futuros outros fatores, através da conceituação dada por Winfried Brugger:

(...) o discurso do ódio refere-se a palavras que tendem a insultar, intimidar ou assediar pessoas em virtude de sua raça, cor, etnicidade, nacionalidade, sexo ou religião, ou que têm a capacidade de instigar violência, ódio ou discriminação contra essas pessoas $(\ldots)^{34}$

Embora o alvo do ódio possa ser a raça, a cultura, a orientação sexual, o gênero, a pobreza ou outras características, é o indivíduo que se torna a vítima e experimenta o dano que o ódio inflige. ${ }^{35}$ Discursos odiosos tendem a desqualificar os grupos vitimizados, por vezes, inclusive, excluindo-os dos debates, de forma a diminuir-lhes a possibilidade de expor suas ideias, opiniões e sensações, sendo forma de negação de desenvolvimento de sua personalidade.

É comum encontrarmos a ideia de que o hate speech é configurado quando há um discurso proferido da maioria contra a minoria, ${ }^{36}$ buscando inferiorizar, depreciar ou desprezar com base em característica diferenciadora e comum entre os membros de grupos alvo, como no caso de praticantes de dogmas religiosos conservadores contra homossexuais. Porém, também nos deparamos com o cenário oposto, isto é, quando grupos historicamente discriminados proferem discursos odiosos contra o grupo

\footnotetext{
${ }^{34}$ BRUGGER, Winfried. Proibição ou proteção do discurso do ódio?: algumas observações sobre o direito alemão e o americano. Brasília: Instituto Brasiliense de Direito Público, ano 4, janeiromarço, 2007. p. 118.

${ }^{35}$ THWEAT, Elizabeth. Bibliography of hate studies materials. Spokane, WA: Journal of hate studies, vs.1, 2001/2002. p. 167.

${ }^{36} \mathrm{O}$ termo "minorias" não necessariamente representa uma minoria numérica, podendo estar diretamente conectada ao conceito de minorias em questão de acesso aos direitos e questões sociais fundamentais, a exemplo da condição da mulher na sociedade, vista como minoria, porém, estando numericamente em maior quantidade que os homens, assim como os pobres em relação a classe social melhor favorecida. MEYER-PFLUG, Samantha Ribeiro. Liberdade de expressão e discurso do ódio. São Paulo: RT, 2009. p.108.
} 
dominante, a exemplo de ofensas proferidas por um judeu contra um jovem alemão. $^{37}$

Apesar do discurso de ódio ser capaz de levar à depreciação e desvalorização de certos grupos estigmatizados, ele não é baseado em mera discordância ou ofensa. O hate speech fere os indivíduos em sua dignidade, no sentido de sua igualdade dentro da comunidade em que está inserido, o acesso à justiça e aos direitos básicos ou aos fundamentos de sua reputação, proclamando com que todos ou quase todos os membros desse determinado grupo sejam, em virtude de características determinantes, considerados não merecedores de tratamento como membros da sociedade. Diferentemente da mera ofensa, caracterizada como uma reação subjetiva do indivíduo, ferindo sentimentos e causando dor ${ }^{38}$ Logo, alguns autores partem do princípio de que ofensas, em geral, devem ser permitidas pelo Direito, estando protegidas pela liberdade de expressão, justamente por esse direito atuar também na defesa de ideias que não são majoritárias em dada sociedade. ${ }^{39}$

Diante das exposições feitas, latente a necessidade de delimitação do que o Direito entende por discurso de ódio, para que, então, possa optar por uma maior liberação ou restrição desses discursos. Há tanto argumentos a favor da liberdade de expressão irrestrita, levantando os fundamentos e objetivos deste direito fundamental, já mencionados no presente trabalho, quanto argumentos de regulação da liberdade de expressão, sendo, uma das formas, a repressão aos discursos odiosos. Neste cenário, é essencial considerar o contexto democrático do país envolvido, a situação de vulnerabilidade das vítimas e a premissa de que o direito à liberdade de

\footnotetext{
${ }^{37}$ MEYER-PFLUG, Samantha Ribeiro. Liberdade de expressão e discurso do ódio. São Paulo: RT, 2009. p.100-101.

${ }^{38}$ WALDRON, Jeremy. The Harm in Hate Speech. Cambridge: Harvard University Press, 2012. p. 105-107.

${ }^{39}$ SILVA, Priscilla Regina da. Os Limites Sagrados da Liberdade: uma análise do discurso de ódio contrarreligioso. Rio de Janeiro. Março de 2017. Dissertação em Pós-Graduação em Direito PUC-Rio. p.17.
} 
expressão é fundamental e, portanto, sua restrição deve ser apenas em casos excepcionais. ${ }^{40}$

$\mathrm{O}$ tratamento constitucional dos problemas aqui referidos estão longe de serem uniformes, pois os limites entre a propagação inadmissível do ódio e a fala protegida variam de país para país, cada qual com sua realidade social e histórica ${ }^{41}$ Existe uma grande divisão de doutrinas entre os Estados Unidos e outras democracias ocidentais, como Alemanha e Canadá, conforme veremos no capítulo 2. A seguir, farei a exposição de doutrinas opostas: de um lado, aqueles que acreditam na restrição dos discursos odiosos, de outro, defensores de uma liberdade de expressão irrestrita, estando o discurso de ódio protegido por esse direito.

\subsubsection{Fundamentos da proteção ao discurso de ódio - liberdade de expressão irrestrita}

Doutrinadores, filósofos e pesquisadores de direito liberais encontram poucas e limitadas justificativas e hipóteses que ensejariam a restrição ao direito fundamental de expressão.

C. Edwin Baker, professor e pesquisador da Universidade de Direito da Pensilvânia, é um desses defensores da forte proteção à liberdade de expressão. $\mathrm{O}$ autor, com este intuito, adota duas premissas: (i) a legitimidade do Estado depende de seu respeito pela igualdade e autonomia de seus cidadãos; (ii) o Estado apenas torna-se apto a respeitar esta autonomia no momento em que permite aos cidadãos a expressão de seus próprios valores, independentemente do conteúdo desses discursos ser capaz de ferir outras pessoas ou dificultar objetivos governamentais. ${ }^{42}$ Baker também defende a ideia de que as proibições aos discursos odiosos não são efetivas em reduzir as chances de resultados horríveis e,

\footnotetext{
${ }^{40} \mathrm{Ibid}$. p.32.

${ }^{41}$ ROSENFELD, Michel. Hate Speech in Constitutional Jurisprudence: A Comparative Analysis. Cardozo Law Review. New York: Working Paper Series No. 41, 2001. Disponível em: $<$ http://papers.ssrn.com/sol3/papers.cfm?abstract_id=265939>. Acesso em: 17 out. 2017.

${ }^{42}$ BAKER, C. Edwin. Hate Speech. Faculty Scholarship. Paper 198, 2008. p. 4-5.
} 
consequentemente, exacerbariam os problemas, confirmando sua primeira premissa $^{43}$. Como forma de confirmação das citadas ideias, o autor desenvolve seis aspectos a serem considerados para a defesa da não restrição ao discurso de ódio.

Primeiramente, o autor entende que proibições ao hate speech podem desviar a energia dos indivíduos de efetuar resposta firme através da crítica a ideias de ódio. Ao retirar esses discursos do debate público, a sociedade não teria a experiência de rebatê-los, colocando a busca pela verdade segundo a teoria de Stuart Mill -, em risco: pessoas perderiam a habilidade de justificar e explicar suas verdades quando desafiadas. Portanto, para o autor, oposições mais ativas a visões racistas, no sentindo de discordar delas, seriam apenas efetivamente alcançadas através das manifestações ativas da sociedade pela não-tolerância e não através de restrições legais ao discurso. ${ }^{44}$

Segundo, proibições à expressão de ódio tendem a tornar a extensão do problema obscura, impedindo que suas vítimas identifiquem seus inimigos. $\mathrm{O}$ conhecimento da existência, posicionamento e identificação dos discursos odiosos aumenta a capacidade de proteção. ${ }^{45}$ A terceira razão levantada pelo autor para instigar a não restrição de discursos de ódio é pelo fato de que as restrições podem aumentar ou criar um sentimento comum de opressão entre grupos que manifestam opiniões de ódio, surgindo, assim, a crença de que precisam agir para alterar o estado das coisas - desta forma, proibições poderiam diminuir o número de "visões proibidas", todavia, aumentariam as chances de resultados violentos. ${ }^{46}$

A quarta premissa de Baker é que a proibição de ideias odiosas possibilita a redução da auto compreensão democrática cultural de que os conflitos deveriam ser solucionados na esfera política, não por meio da

\footnotetext{
${ }^{43}$ Ibid. p. 14.

${ }^{44}$ Ibid. p. 14-15.

${ }^{45}$ Ibid. p.16.

${ }^{46}$ Ibid. p. 16-17.
} 
violência. ${ }^{47} \mathrm{~A}$ democracia, portanto, não significa a eliminação do conflito, mas o desvio da sociedade do conflito violento para o político.

A quinta ideia é de que programas políticos que se preocupam em promulgar e colocar em prática restrições ao hate speech correm o risco de usar a energia política para tal finalidade ao invés do que realmente deveria importar: a alteração da condição social que permite a alienação de grupos e manutenção das discriminações, uma vez que as causas dessa alienação não se restringem no discurso. Mudando estas condições, além de criar contextos de neutralização de atitudes de ódio, mudanças significativas na probabilidade de violência tornar-se-iam hipóteses plausíveis. ${ }^{48}$ Por fim, o autor defende que as proibições legais provavelmente serão utilizadas abusivamente por pessoas detentoras de poder, criando uma "rampa escorregadia" (slippery slope ${ }^{49}$ originalmente) de resultados contrários as necessidades das vítimas do ódio ${ }^{50}$.

A partir destas premissas, Baker defende que a diminuição da liberdade de expressão contribuirá para a possibilidade de corrupção do uso das restrições legais, com consequências violentas e desastrosas. ${ }^{51} \mathrm{O}$ ideal no combate dos discursos odiosos, para o autor, seria através da ampla discussão de ideias entre a sociedade - audiências públicas - e programas políticos que se concentram na busca de repressão das condições sociais que permitem que os discursos odiosos surjam e multipliquem-se.

Anthony Lewis segue na mesma orientação. A maior flexibilização de discursos, aumentando a proteção ao direito de expressão, mesmo para ideias que possam exprimir ódio, é favorável à sociedade, que passa a conhecer opiniões de ódio, permitindo que o combate seja realizado. Em

\footnotetext{
${ }^{47}$ Ibid. p. 17.

${ }^{48}$ Ibid. p. 17-18.

49 Teoria segundo a qual a existência de proibições da liberdade de expressão, por meio de leis específicas, por exemplo, criam o risco de que estas limitações sejam ampliadas até o ponto de total restrição desta liberdade, a partir do pressuposto de que leis proibitivas são passíveis de abuso. BAKER, C. Edwin. Hate Speech. Faculty Scholarship. Paper 198, 2008. p. 19.

${ }^{50}$ Ibid. 19-20.

${ }^{51}$ Ibid. p. 21.
} 
outras palavras, para o autor, um dos argumentos a favor da permissão do hate speech é o desenvolvimento da ciência de existência de crenças horríveis, fortalecendo o desejo de combatê-las. ${ }^{52}$ A Primeira Emenda da Constituição dos Estados Unidos, protetora da liberdade de expressão, não serviria apenas para proteção de opiniões e ideias eticamente corretas e defendidas pela ampla maioria da sociedade, mas também atuaria na proteção daqueles discursos que profanam, desrespeitam e manifestam ódio a certos grupos da sociedade..$^{53}$

Pertinente voltarmos às ideias defendidas por John Stuart Mill em seu livro On Liberty, a partir de seus conceitos, precursores da noção de mercado livre de ideias - esta teoria permite a interpretação de que a limitação dos discursos odiosos através de legislações impediria a concretização dos objetivos da liberdade de expressão: busca da verdade, autogoverno com consequente legitimidade do princípio democrático, autossatisfação individual dos indivíduos através do desenvolvimento de suas personalidades de forma autônoma e livre e a construção de uma sociedade mais tolerante e aberta à pluralidade de ideias. ${ }^{5455}$

Nesta linha, o discurso de ódio não deveria ser restringido, mas sim aceito, como forma de garantir a validade das verdades já existentes na sociedade, opostas ao ódio expresso, permitindo que a democracia seja também fortalecida através da ampla divulgação das mais variadas formas de ideias e que os indivíduos optem por aquelas que sejam relevantes para a defesa de seus ideais. Ademais, a liberação do discurso de ódio possibilitaria o confronto direto de ideias, diminuindo as chances de violência concreta e estimulando a reflexão de ideias que baseiam seu combate, além de permitir que a sociedade tolere diferenças de opinião, sem deixar de expor suas críticas capazes de fomentar o repúdio ao ódio. Dentro

\footnotetext{
${ }^{52}$ LEWIS, Anthony. Liberdade Para as Ideias que Odiamos: Uma Biografia da Primeira Emenda à Constituição Americana. São Paulo: Aracati, 2011.p.192.

${ }^{53} \mathrm{Ibid}$. p. 54.

${ }^{54}$ Vide item 1.1.

${ }^{55}$ MILL, John Stuart. On Liberty (1859). Kitchener: Batoche Books, 2001. p. 18-52
} 
deste cenário, portanto, a sociedade deveria tolerar inclusive os discursos que odeia, uma vez que a verdade terá mais chances de surgir em um combate intelectual livre em que nenhuma ideia foi excluída. ${ }^{56}$

Ronald Dworkin, um dos principais defensores da liberdade de expressão da atualidade, alega que doutrinadores e advogados constitucionais propuseram duas categorias definidoras da importância deste direito: (i) importância instrumental da liberdade de expressão, isto é, a liberdade não seria apenas importante porque as pessoas têm o direito moral intrínseco de dizer o que desejam, mas porque a permissão que elas o digam trará efeitos benéficos para a sociedade em geral - apesar de Dworkin não ser completamente a favor da utilização desta justificação pelos Tribunais; ${ }^{57}$ (ii) justificativa constitutiva da liberdade de expressão em uma sociedade liberal, possuidora de responsabilidade moral individual, nenhuma censura de conteúdo é compatível com a liberdade de expressão. O Estado deve tratar todos os seus cidadãos capazes como moralmente responsáveis por sua tomada de decisões e permitir que se expressem para os demais integrantes da sociedade, por mais odiosas que essas ideias possam ser. ${ }^{58}$ Ambas categorias são igualmente justificadoras da orientação do autor de não restrição dos discursos de ódio por meio de leis.

Em descrição de aspectos relevantes sobre a aula inaugural de Isaiah Berlin, em 1958, Dworkin enfatizou também dois aspectos da liberdade: liberdade negativa (direito de não ser impedido pelos outros de fazer o que se deseja) e positiva (poder e direito de participar das decisões públicas e controla-las). ${ }^{59}$ Ao desenvolver tal argumento, o autor defende que a essência da liberdade negativa é a liberdade de ofender, não se aplicando somente as formas de expressão heroicas, mas também as de mau gosto,

\footnotetext{
56 DWORKIN, Ronald. Foreword to Extreme Speech and Democracy. In.: HARE, Ivan; WEINSTEIN, James (editors). Extreme Speech and Democracy. New York: Oxford University Press, 2009. p. v-ix.

${ }^{57}$ DWORKIN, Ronald. Por que a liberdade de expressão. In: $O$ Direito da Liberdade: A Leitura Moral da Constituição Norte-Americana. São Paulo: Martins Fontes Editora, 2006. p.319-343.

${ }^{58}$ Ibid. p.319-321.

${ }^{59}$ Ibid. p. 345.
} 
que podem chocar ou levar ao menosprezo, como é o caso do hate speech. ${ }^{60}$ Nesse sentido, não devemos sustentar o princípio de que aqueles que estão no poder sejam dotados de uma cognição diferenciada, a ponto de definir quais ideias são falsas e, consequentemente, devem ser proibidas, de forma a evitar que algum grupo seja profundamente ferido, caso estas sejam expressas, a exemplo dos criacionistas, que proibiram o ensino da teoria darwinista em escolas públicas do Tennessee na década de 20 por acreditarem estar lutando pela verdade. ${ }^{61}$

Em oposição àqueles que acreditam que a liberdade de expressão está em contradição ao princípio da igualdade, como forma de justificar as restrições impostas ao discurso de ódio, Dworkin sustenta que a igualdade é essencial para a manutenção da liberdade e que estes direitos se complementam. Defende, assim, que a Primeira Emenda do Bill of Rights tem enorme contribuição à igualdade política, no sentido de que assim como ninguém pode ser proibido de votar, também não se pode negar a ninguém o direito de falar, escrever ou manifestar-se por quaisquer meios pelo fato de as opiniões serem insultuosas. ${ }^{62}$ Em suas palavras:

Ela [a primeira emenda] proíbe a censura dos pervertidos sexuais ou dos neonazistas, não porque alguém pense que as contribuições deles vão impedir a corrupção ou melhorar a qualidade do debate público, mas porque a igualdade exige que todos, por mais excêntricos ou desprezíveis que sejam, tenham a oportunidade de exercer sua influência não só nas eleições, mas na política em geral (...). O que a igualdade exige é que todas as opiniões tenham a oportunidade de exercer sua influência, e não que todas triunfem ou mesmo sejam representadas naquilo que o Estado efetivamente faz. ${ }^{63}$

A função igualitária da Primeira Emenda possui um segundo aspecto, relacionado ao ambiente moral. Ninguém pode ser impedido de influenciar o ambiente moral comum através de suas escolhas livres de vida, gostos e opiniões - o fato de estas expressões chocarem aqueles que

\footnotetext{
${ }^{60}$ Ibid. p. 351.

${ }^{61}$ Ibid. p. 361.

62 DWORKIN, Ronald. Pornografia e ódio. In: $O$ Direito da Liberdade: A Leitura Moral da Constituição Norte-Americana. São Paulo: Martins Fontes Editora, 2006. p. 379.

${ }^{63}$ Ibid. p.380.
} 
têm o poder de prender ou calar a pessoa não é motivo suficiente para que o indivíduo não tenha o direito e garantia de manifestar-se. ${ }^{64}$ Portanto, as restrições à liberdade de expressão, através de legislações contrárias ao discurso de ódio, além de ofender a Primeira Emenda, são violadores da igualdade, não devendo o Estado atuar com ideal paternalista. Não haveria como promover a proteção da igualdade sem a garantia da liberdade.

Como já expresso, Dworkin atribui a liberdade de expressão função essencial de permitir um debate amplo e plural de ideias, de forma a permitir a formação de cidadãos (eleitorado) informados, definindo também a liberdade de expressão como elemento determinante para a existência da democracia. Nesse contexto, a garantia da expressão livre protegeria também discursos de ódio, que são importantes para alarmar a sociedade dos problemas enfrentados, de forma a criar ações afirmativas que possibilitem a inclusão de grupos oprimidos. Consequentemente, para o autor, as consequências prejudiciais de atitudes sexistas, intolerantes e racistas, através do hate speech, devem ser combatidas com ações sociais por parte do Estado, como a garantia de emprego, educação e processo penal justo para os grupos subjugados e não pelo silêncio forçado de algumas pessoas. ${ }^{65} \mathrm{~A}$ genuína liberdade de expressão, portanto, exige mais do que a mera ausência de proibições legais, mas também outras formas de prover pessoas pobres ou sem influência de fazer com que suas vozes sejam ouvidas. ${ }^{66}$

Para que a decisão da maioria seja efetivamente justa, é imprescindível que todos os membros da sociedade tenham tido oportunidade de pronunciar-se sobre o tema, mesmo que através de

\footnotetext{
${ }^{64}$ Ibid. p. 380-381.

${ }^{65}$ DWORKIN, Ronald. Foreword to Extreme Speech and Democracy. In.: HARE, Ivan; WEINSTEIN, James (editors). Extreme Speech and Democracy. New York: Oxford University Press, 2009. p. v-ix; SILVA, Priscilla Regina da. Os Limites Sagrados da Liberdade: uma análise do discurso de ódio contrarreligioso. Rio de Janeiro. Março de 2017. Dissertação em PósGraduação em Direito - PUC-Rio. p.35.

${ }^{66}$ DWORKIN, Ronald. Foreword to Extreme Speech and Democracy. In.: HARE, Ivan; WEINSTEIN, James (editors). Extreme Speech and Democracy. New York: Oxford University Press, 2009. p. v-ix.
} 
opiniões horríveis ou preconceitos, não se enquadrando na condição de meras vítimas da decisão imposta pela maioria. Por esta premissa, Dworkin defende que as leis devem ser criadas em ambiente de amplo debate, onde todas as ideias e opiniões, inclusive as odiosas, sejam expressas, para que esta legislação seja, portanto, legítima. Desta forma, leis, ou decisões coletivas, impostas sobre alguém que não tenha contribuído para o debate, retira o motivo deste indivíduo obedecer tais proposições. Por isso, intolerantes não teriam motivos para seguir legislações, cujos processos legislativos nunca participaram amplamente. Estando a liberdade de expressão ausente, a legitimidade legal fica manifestamente prejudicada uma lei é apenas legítima se o debate livre for permitido. ${ }^{67}$

Dworkin sustenta que, atualmente, a liberdade de expressão vem sendo desafiada; não apenas por seus antigos "oponentes" (déspotas e tiranos), mas por novos "inimigos" que pedem por justiça, não tirania estes apontam valores que defensores da liberdade também respeitam, como autogoverno, igualdade e liberdade do ódio racial e preconceito, sugerindo restrições legais à liberdade de expressão,${ }^{68}$ através da repressão ao discurso de ódio por legislações, em busca de proteção de outros direitos fundamentais, o que colocaria a liberdade de expressão a um nível de proteção muito menor. ${ }^{69}$ Desta forma, o próximo tópico busca expor fundamentos opostos ao que é defendido por Ronald Dworkin, através da exposição das razões que levam a criação de restrições ao discurso de ódio.

\footnotetext{
${ }^{67}$ Ibid.

${ }^{68}$ Dworkin entende como plausível raras hipóteses de restrição à liberdade de expressão, quando busca reprimir expressões eminentemente perigosas, a exemplo de quando alguém grita "Fogo!" em lugar fechado e lotado, ou quando há clara incitação à violência ou carros com alto-falantes durante a noite. A restrição, contudo, não pode ser apenas baseada no fato de a ideia exposta ser má ou expressar ideias que não deveriam ser ouvidas de modo algum. Neste último caso, o autor defende a liberdade de maneira ampla. DWORKIN, Ronald. Pornografia e ódio. In: $O$ Direito da Liberdade: A Leitura Moral da Constituição Norte-Americana. São Paulo: Martins Fontes Editora, 2006. p. 351.

${ }^{69}$ DWORKIN, Ronald. Foreword to Extreme Speech and Democracy. In.: HARE, Ivan; WEINSTEIN, James (editors). Extreme Speech and Democracy. New York: Oxford University Press, 2009. p. v-ix.
} 


\subsubsection{Fundamentos da repressão ao discurso de ódio - limites à liberdade de expressão}

Apesar de a garantia à liberdade de expressão ser um direito humano presente em ordenamentos jurídicos nacionais e tratados internacionais, com o crescimento da incidência de hipóteses e ocorrências de discursos odiosos, alguns doutrinadores passaram a defender a possibilidade de restrição a essa liberdade, em prol de outros direitos igualmente fundamentais. Portanto, o presente tópico tem o escopo de buscar relacionar os objetivos e fundamentos da liberdade de expressão, já expostos, e a possibilidade de restrições ao discurso de ódio, através da análise de doutrina.

Alex Potiguar entende o discurso de ódio como uma forma de manifestação do "desrespeito à estrutura performativa da comunicação", pois aqueles que fazem manifestações com o objetivo de menosprezar e atingir certos grupos pré-determinados não os veem como iguais, não tendo, portanto, esse discurso pretensões de validade. O hate speech, com suas características depreciativas e de menosprezo de grupos, não deveria ser enquadrado como liberdade de expressão e, menos ainda, protegido por esse direito. ${ }^{70}$

O espaço público de ideias, defendido pela teoria da liberdade de expressão como direito preferencial, aberto a todo tipo de discurso, inclusive àquele que despreza, ofende e diminui determinados grupos, não pode ser visto como cenário ideal para tomada de decisões entre membros de uma sociedade. Potiguar afirma que o respeito mútuo entre aqueles que debatem é pressuposto essencial para o debate de ideias, possibilitando que todos se reconheçam como livres e iguais. ${ }^{71} \mathrm{O}$ autor afirma que o cenário de um mercado livre de ideias para a busca da verdade é inviabilizado pelo

\footnotetext{
${ }^{70}$ POTIGAR, Alex Lobato. Igualdade e Liberdade: a luta pelo reconhecimento da igualdade como direito à diferença no Discurso do Ódio. Brasília. 2009. Dissertação em Pós-Graduação em Direito - Universidade de Brasília. p. 44-45.

${ }^{71}$ Ibid. p. 35.
} 
discurso de ódio, aproximando-se mais de um contexto de ataque do que de um efetivo debate de opiniões com ampla participação de diversos e variados grupos sociais, sendo negado o debate racional de ideias. Ademais, em contexto social de domínio da mídia por grandes empresas, o pressuposto de que todos possuem acesso à informação e iguais oportunidades de serem informados e de informar é fraco, tornando desigual o acesso e deslegitimando a teoria defendida por John Stuart Mill.

Para Kathleen Mahoney, o discurso de ódio não é uma mera ofensa, constituindo um ataque sério na saúde psicológica e emocional de suas vítimas. A sociedade como um todo sofre com essas expressões, capazes de minar a liberdade e os valores democráticos, ao criar desacordo entre grupos e atmosfera de discriminação e violência. Segundo a autora, a propaganda de ódio não é uma mera intenção de agir no futuro, é um ato, uma consequência por si só, como veremos mais à frente, a partir da teoria de J.L Austin e Catherine Mackinnon. No melhor dos casos é uma prática de discriminação, no pior, é violência pura. ${ }^{72}$ Nas palavras de Mahoney:

O que deve ser entendido é que, qualquer que seja a sua forma, o propósito e efeito da propaganda do ódio é estabelecer as bases para o maltrato de membros do grupo vitimado. Os membros de tais grupos respondem à propaganda do ódio com medo e se retiram da participação plena na sociedade.

(...) o discurso de ódio não-violento existe em uma continuidade que eventualmente e inevitavelmente leva à violência, uma vez que as armas de segregação, desânimo e propaganda fizeram seu trabalho. ${ }^{73}$

Para a autora, leis devem ser usadas para proteger os cidadãos contra o discurso odioso, uma vez que o maior propósito do sistema legal é a

\footnotetext{
${ }^{72}$ MAHONEY, Kathleen. Hate Vilification Legislation And Freedom Of Expression: Where Is The Balance?. Disponível em: $<$ http://www.austlii.edu.au/au/journals/AUJlHRights/1994/21.htmll . Acesso em: 17 out. 2017.

${ }^{73} \mathrm{Ibid}$. Citação original: What must be understood is that whatever form it takes, the purpose and effect of hate propaganda is to lay the foundation for the mistreatment of members of the victimised group. Members of such groups respond to hate propaganda by being fearful and withdrawing from full participation in society.

(...) Both are connected. Non-violent hate speech exists on a continuum which eventually and inevitably leads to violence once the weapons of segregation, disparagement and propaganda have done their work.
} 
proteção da existência básica da humanidade. Nesse contexto, Mahoney defende que a ideia do mercado livre de ideias está obsoleta, ignorando o dano aos grupos alvo, diminuindo o valor de outros valores democráticos. As modernas democracias, que respeitam a igualdade e multiculturalismo, aceitaram, como princípio fundamental, que a proteção legal e regulação governamental são essenciais para proteção dos vulneráveis. ${ }^{74}$

De acordo com Daniel Sarmento, o cenário do mercado livre de ideias, para a tomada de decisões e busca da verdade, não se reproduz integralmente em nenhuma sociedade moderna, estando inviabilizado pelo discurso de ódio, uma vez que as vítimas, diante destas manifestações, comportam-se de duas maneiras distintas: revidando com igual violência ou retirando-se do debate, humilhadas e com medo - de certo, nenhuma destas hipóteses contribui para a busca da verdade. ${ }^{75}$ Em outras palavras:

O fato de uma ideia ser considerada errada não é base suficiente para sua supressão da arena da discussão. Este é o pilar fundamental da liberdade de expressão, que não deve ser ameaçado. (...) a busca da verdade e do conhecimento não justifica a proteção ao hate speech, mas, pelo contrário, recomenda a sua proibição. ${ }^{76}$

Defensores da liberdade de expressão irrestrita, como Ronald Dworkin, defendem que a proteção ao discurso de ódio é forma de garantir a legitimidade do princípio democrático, ao permitir que todos tenham voz, inclusive aqueles que discursam o ódio, sendo que as leis que tendem a proibi-lo também não seriam legítimas, pois não contariam com a participação daqueles que profanam discursos de ódio. Em oposição a esta visão, Jeremy Waldron sustenta que a manutenção da democracia, como

\footnotetext{
${ }^{74}$ MAHONEY, Kathleen. Hate Vilification Legislation And Freedom Of Expression: Where Is The Balance? Disponível em: $<$ http://www.austlii.edu.au/au/journals/AUJlHRights/1994/21.htmll . Acesso em: 17 out. 2017.

${ }^{75}$ SARMENTO, Daniel. A Liberdade de Expressão e o Problema do Hate Speech. Rio de Janeiro, 2006. Disponível em <http://www.dsarmento.adv.br/content/3-publicacoes/18-a-liberdade-deexpressao-e-o-problema-do-hate-speech/a-liberdade-de-expressao-e-o-problema-do-hate-speechdaniel-sarmento.pdf>. Acesso em: 17 out. 2017.

76 Ibid. Disponível em <http://www.dsarmento.adv.br/content/3-publicacoes/18-a-liberdade-deexpressao-e-o-problema-do-hate-speech/a-liberdade-de-expressao-e-o-problema-do-hate-speechdaniel-sarmento.pdf>. Acesso em: 17 out. 2017.
} 
entendemos hoje, não será possível sem que haja a proibição de certos discursos, como o hate speech, fortalecendo a democracia, ao invés de enfraquece-la. ${ }^{77}$ Aqueles que defendem e expressam o ódio não possuem, necessariamente, razões para seguir os princípios enquadrados em uma democracia, por isso, para que a sociedade esteja em ordem é necessário que estes indivíduos desistam do propósito de manifestar-se através do ódio direcionado, aceitando os princípios da justiça. ${ }^{78}$

Nesse sentido, Waldron é um dos defensores da atuação do Estado, criando leis que restrinjam a liberdade de expressão no contexto do discurso de ódio. Por "regulação do discurso de ódio", Waldron entende ser exemplo a regulação que pode ser encontrada no Canadá, Dinamarca, Alemanha, Nova Zelândia e Inglaterra, ${ }^{79}$ estabelecendo duas razões iniciais para a aceitação das legislações que tratam da proibição dos discursos de ódio. Primeiramente, permite um sentimento de segurança de que todos habitamos em um bom ambiente comum, destruído pela existência de hate speech. Segundo, para os membros dos grupos vulneráveis, a proibição destas manifestações através de lei é a confirmação de sua condição de membro na sociedade, confirmando serem seres possuidores de dignidade, que deve ser mantida e respeitada. ${ }^{80}$

Para Waldron, as leis que buscam a regulação e restrição do discurso de ódio devem ser, para que atinjam seu fim, restritas apenas àqueles casos que tratam de ataques à dignidade de indivíduos como membros

\footnotetext{
${ }^{77}$ WALDRON, Jeremy. The Harm in Hate Speech. Cambridge: Harvard University Press, 2012. p. 180-203.

${ }^{78}$ Ibid. p. 78.

${ }^{79}$ Ibid. p.8. By "hate speech regulation," I mean regulation of the sort that can be found in Canada, Denmark, Germany, New Zealand, and the United Kingdom, prohibiting public statements that incite "hatred against any identifiable group where such incitement is likely to lead to a breach of the peace" (Canada); or statements "by which a group of people are threatened, derided or degraded because of their race, colour of skin, national or ethnic background" (Denmark); or attacks on "the human dignity of others by insulting, maliciously maligning or defaming segments of the population" (Germany); or "threatening, abusive, or insulting words likely to excite hostility against or bring into contempt any group of persons ... on the ground of the colour, race, or ethnic or national or ethnic origins of that group of persons" (New Zealand); or the use of "threatening, abusive or insulting words or behaviour," when these are intended "to stir up racial hatred," or when "having regard to all the circumstances racial hatred is likely to be stirred up thereby" (United Kingdom).

${ }^{80} \mathrm{Ibid}$. p. 5-6.
} 
pertencentes a uma sociedade e não a mera ofensa, uma vez que a ação estatal não busca a proteção dos sentimentos das pessoas, mas sim a garantia do indivíduo de ser respeitado em sua dignidade, não estando em posição vulnerável à discriminação e humilhação social, além de promover a segurança. ${ }^{81}$

A intenção do autor, portanto, é que a intervenção jurídica, através da lei, seja em ultima ratio, quando o discurso estaria potencialmente próximo de uma ação física efetiva, através da análise de seu conteúdo ${ }^{82}$. Desta maneira, ao restringir o discurso de ódio, seria possível manter a ordem social e, consequentemente, a garantia da manutenção do Estado e da ordem democrática, ${ }^{83}$ sem que haja a exclusão dos intolerantes do debate de ideias, uma vez que há a possibilidade de argumentação contra uma lei antidiscriminação sem envolver o discurso de ódio, mantendo a legitimidade do processo democrático. ${ }^{84}$

Waldron também defende que a restrição ao discurso de ódio não seria ameaça à democracia, mas sim forma de fortalece-la. As restrições não envolvem, necessariamente, o estabelecimento de limites perfeccionistas ao debate público, impedindo que os dissidentes se manifestem contra a tomada de decisão da maioria - a proibição não deve ser entendida como vedação ao dissenso em relação aos valores básicos de uma sociedade, mas como instrumento necessário à garantia da integridade do próprio discurso público, estabelecendo igual dignidade a todos os participantes. ${ }^{85}$

\footnotetext{
${ }^{81}$ Ibid. p. 106-107.

${ }^{82}$ Ibid. p. 151. Neste ponto, Waldron sustenta que as restrições legais do conteúdo do discurso de ódio são apenas quando ele é expresso de forma abusiva, insultante ou ameaçadora para aos grupos vulneráveis atingidos. Em suas palavras: “(...) we want to catch only hate speech that is expressed in an abusive, insulting, or threatening way.".

${ }^{83}$ SILVA, Priscilla Regina da. Os Limites Sagrados da Liberdade: uma análise do discurso de ódio contrarreligioso. Rio de Janeiro. Março de 2017. Dissertação em Pós-Graduação em Direito PUC-Rio. p. 47.

${ }^{84}$ WALDRON, Jeremy. The Harm in Hate Speech. Cambridge: Harvard University Press, 2012. p. 198.

${ }^{85}$ SARMENTO, Daniel. A Liberdade de Expressão e o Problema do Hate Speech. Rio de Janeiro, 2006. Disponível em <http://www.dsarmento.adv.br/content/3-publicacoes/18-a-liberdade-deexpressao-e-o-problema-do-hate-speech/a-liberdade-de-expressao-e-o-problema-do-hate-speechdaniel-sarmento.pdf $>$. Acesso em: 17 out. 2017.
} 
A autonomia individual também é um dos fundamentos da liberdade de expressão, por ser considerada parte da dignidade da pessoa, e ser responsável pela formação de opiniões em um ambiente repleto de informações plurais. Sarmento concorda com a posição de que a proibição de ideias, por mais abomináveis que sejam, restringem a autonomia do indivíduo (daqueles que desejam espalhá-la e do público em geral). No entanto, para ele, esta perda de autonomia pode ser entendida como positiva, pois permite a autorrealização e autonomia de grupos alvo destas manifestações de preconceito e ódio, uma vez que a autorrealização e o desenvolvimento da personalidade pressupõem a autoestima, destruída com a proliferação do hate speech, especialmente sob grupos sociais já estigmatizados. Portanto, as restrições às expressões de ódio possuem, segundo o autor, efeito dúplice sobre a autonomia individual e a capacidade de autossatisfação, pois, ao mesmo tempo, atuam em sua restrição, promoção e garantia. ${ }^{86}$

A liberdade de expressão, em sua forma mais plena, também é considerada como maneira mais fácil de garantir a tolerância entre membros da sociedade, ao permitir o debate entre todos os tipos de ideias e opiniões, estimulando o multiculturalismo e o respeito as diferenças. Em oposição a tal premissa, Karl Popper afirmava, porém, que não se deve tolerar aquele que, tendo oportunidade, suprimiria a própria tolerância. A tolerância ilimitada, necessariamente, conduz ao desaparecimento da própria tolerância, pois, ao ampliarmos os limites do que se entende como tolerável aos intolerantes, a intolerância prevaleceria sobre a sociedade. Portanto, em nome da tolerância, ao invés de permitir o debate absolutamente livre de ideias, o Estado deveria coibir e punir os

86 Ibid. Disponível em <http://www.dsarmento.adv.br/content/3-publicacoes/18-a-liberdade-deexpressao-e-o-problema-do-hate-speech/a-liberdade-de-expressao-e-o-problema-do-hate-speechdaniel-sarmento.pdf>. Acesso em: 17 out. 2017. 
intolerantes, tendo o direito de não tolerar os intolerantes. ${ }^{87}$ Nas palavras de Daniel Sarmento:

(...) diante de violações e ameaças de direitos humanos, a resposta correta do Estado não é a tolerância. O seu papel, pelo contrário, é o de buscar evitar lesões e, caso isto não seja possível, punir os culpados e amparar as vítimas. (...) o hate speech envolve, sim, uma grave violação destes direitos. ${ }^{88}$

Em oposição também àqueles que defendem o discurso de ódio como protegido pela liberdade de expressão, necessário abordar a teoria do discurso como fala. J. L. Austin, em seu livro "Quando dizer é fazer: palavras e ação", constatou que nem todas as declarações atuam apenas descrevendo um estado de coisas ou declarando um fato (discursos constatativos), podendo também vir a prescrever comportamentos, indicar o modo como a declaração deve ser recebida, além de outras formas de ações como, por exemplo, quando os noivos, em um casamento, declaram "sim", formalizando $\mathrm{o}$ ato de casar - sendo estes atos conhecidos como performativos. ${ }^{89}$ Desta forma, as palavras não seriam apenas formas de descrição, mas um ato em si, praticado, podendo sua força gerar efeitos em seus interlocutores.

Utilizando conceitos de Austin, Mari Matusa classifica o discurso de ódio como um ato de fala ilocucionário, em outras palavras, aquele que, quando proferido, atribui ao seu receptor, vítima, posição social inferior à daquele que o proferiu - assumindo, desta forma, uma força ilocucionária,

\footnotetext{
${ }^{87}$ Ibid. Disponível em <http://www.dsarmento.adv.br/content/3-publicacoes/18-a-liberdade-deexpressao-e-o-problema-do-hate-speech/a-liberdade-de-expressao-e-o-problema-do-hate-speechdaniel-sarmento.pdf $>$. Acesso em: 17 out. 2017.

SILVA, Priscilla Regina da. Os Limites Sagrados da Liberdade: uma análise do discurso de ódio contrarreligioso. Rio de Janeiro. Março de 2017. Dissertação em Pós-Graduação em Direito PUC-Rio. p. 31-32.

${ }^{88}$ SARMENTO, Daniel. A Liberdade de Expressão e o Problema do Hate Speech. Rio de Janeiro, 2006. Disponível em <http://www.dsarmento.adv.br/content/3-publicacoes/18-a-liberdade-deexpressao-e-o-problema-do-hate-speech/a-liberdade-de-expressao-e-o-problema-do-hate-speechdaniel-sarmento.pdf>. Acesso em: 17 out. 2017.

${ }^{89}$ AUSTIN, J. L. Quando dizer é fazer: palavras e ação. Porto Alegre: Artes Médicas, 1990. p. 2127.
} 
no sentido de cumprir o que se propõe. ${ }^{90} \mathrm{O}$ discurso de ódio, repetido e perpetuado ao longo do tempo em determinada sociedade, é capaz de criar um ambiente de discriminação que atua oprimindo grupos específicos, renovado a cada ato de fala praticado - sendo, por si só, uma força violenta, que não precisaria culminar em atos para configuração da violência, uma vez que teria capacidade de ameaçar a própria existência dos indivíduos, desconstruindo sua condição de sujeitos, sendo reconstruídos de acordo com a visão daquele que profere o discurso. ${ }^{91}$

Neste mesmo sentido, Catherine Mackinnon, em sua luta pela proibição da pornografia - vista pela autora como uma das manifestações odiosas - entende que o discurso de ódio é capaz de realizar o que se profere. ${ }^{92}$ Para a autora, o discurso de ódio não deve ser proibido apenas pelo que diz, mas pelos efeitos com relação às vítimas na sociedade, em seu exemplo da pornografia, subordinando as mulheres através do sexo. ${ }^{93} \mathrm{O}$ Estado, ao permitir a liberdade de expressão absoluta, protege o discurso de ódio, silenciando aqueles que foram feridos por estas manifestações, dando certeza que as vítimas não podem fazer nada para mudar essa situação. ${ }^{94}$ Nas palavras de Mackinnon:

A discriminação não se divide em atos de um lado e fala de outro. Falas agem. Também não faz sentido do lado da ação. Atos falam. No contexto da desigualdade social, o chamado discurso pode ser um exercício de poder que constrói a realidade social em que as pessoas vivem, da objetivação ao genocídio. As palavras e imagens são incidentes diretos de tais atos, como fazer pornografia ou exigir que os judeus usem estrelas amarelas, ou estão conectados a elas, de forma imediata, linear e direta, ou de maneiras mais complicadas e estendidas. ${ }^{95}$

\footnotetext{
${ }^{90}$ Ibid. p.85-120; SILVA, Priscilla Regina da. Os Limites Sagrados da Liberdade: uma análise do discurso de ódio contrarreligioso. Rio de Janeiro. Março de 2017. Dissertação em Pós-Graduação em Direito - PUC-Rio. p. 60.

91 BUTLER, Judith. Excitable Speech: A Politics of the Performative. New York: Routledge, 1997. p.2; SILVA, Priscilla Regina da. Os Limites Sagrados da Liberdade: uma análise do discurso de ódio contrarreligioso. Rio de Janeiro. Março de 2017. Dissertação em Pós-Graduação em Direito - PUC-Rio. p. 60-61.

92 MACKINNON, Catharine. Only Words. 3th edition. Cambridge: Harvard University Press, 1996. p. 13-18.

${ }^{93}$ Ibid. p. 23.

${ }^{94}$ Ibid. p. 40

${ }^{95}$ Ibid. p. 30-31.
} 
A autora, então, defende que o discurso de ódio não apenas trata de uma relação de dominação pré-existente, mas atua reforçando tal dominação de um grupo sobre o outro, oprimido e silenciado, impedindo que estes sejam capazes de opor-se. É uma prática social que vai além de mera opinião, é também um ato discriminatório, que coloca, majoritariamente, minorias em posição desigual, permitindo que sejam subordinados e tenham sua identidade destruída, silenciando a expressão dos grupos atingidos. ${ }^{96}$ Desta forma, ao permitir o discurso de ódio, protegido pela liberdade de expressão, a legitimação democrática, busca da verdade, autorrealização individual e tolerância não seriam aplicadas a esses grupos historicamente estigmatizados.

Somando todos os argumentos, é de fácil constatação que os doutrinadores, estudiosos e filósofos, defensores das leis que regulam e restringem o discurso de ódio, não entendam ser a liberdade de expressão um direito humano e fundamental absoluto, compreendendo o discurso de ódio como hipótese não abrangida dentro de sua proteção, sendo, para eles, latente a necessidade de restrições a essa forma de expressão, que não atua na busca pela verdade, não traz legitimidade à democracia, não promove maior autossatisfação individual nem estimula a tolerância entre as ideias plurais, uma vez que os grupos atingidos pelo hate speech tendem a retirarse do cenário de debate, não manifestando suas concepções nem clamando por seus direitos, promovendo contexto ainda maior de intolerância entre grupos de uma mesma sociedade.

Portanto, terminada aqui a discussão doutrinária entre defensores da liberdade de expressão como direito preferencial e aqueles que pedem por limitação a este direito, na hipótese do discurso de ódio, no próximo capítulo farei a análise da situação do Direito Comparado, ao contrapor o entendimento difundido nos Estados Unidos e em países Europeus, como a Alemanha, além do panorama geral do Direito Internacional sobre o

\footnotetext{
${ }^{96}$ MACKINNON, Catherine. Are women human? And other international dialogues. Cambridge: Harvard University Press, 2007, p. 227.
} 
assunto. Por fim, trarei alguns standards para a problemática, através de documentos que consolidam entendimentos internacionais de Direitos Humanos. 


\section{CAPÍTULO 2 - PARÂMETROS INTERNACIONAIS: POSSIBILIDADE OU NÃO DE RESTRIÇÃO AOS DISCURSOS ODIOSOS}

Como exposto no capítulo anterior, existem argumentos doutrinários no sentido de permitir e de proibir o discurso de ódio. Dentro deste contexto, há duas tendências diversas no tratamento desta problemática, que serão analisados no presente capítulo.

De um lado, há ordenamentos que tendem a dar maior proteção à liberdade de expressão, mesmo quando o discurso está repleto de ódio ou expressões odiosas, em detrimento de outros direitos e interesses, com poucos casos de restrições ao discurso de ódio $-{ }^{97}$ nesta posição, o país que mais se destaca é os Estados Unidos, referido no presente trabalho como parte essencial dentro do sistema americano de proteção ao hate speech, conjuntamente com o Sistema Interamericano de Direitos Humanos. ${ }^{98}$

Em oposição, encontram-se os países onde a dignidade da pessoa humana e a igualdade são preponderantes, com ampla proteção às vítimas do discurso de ódio - dentro deste cenário, está a maioria dos países europeus, dentro dos quais optei pela abordagem mais minuciosa do cenário da Alemanha, além da Corte Europeia de Direitos Humanos, entendidos, no presente trabalho, como sistema europeu de combate ao discurso de ódio.

\subsection{Sistema americano de proteção ao discurso de ódio}

\subsubsection{Estados Unidos}

\footnotetext{
97 BRUGGER, Winfried. The Treatment of Hate Speech in German Constitutional Law. Charlottesville: German Law Journal, Vol. 4, nº 1, 2003. p. 2.

98 Apesar de considerar, no presente trabalho, os Estados Unidos e o Sistema Interamericano de Direitos Humanos como defensores da mínima restrição aos discursos odiosos, ressalto que esta orientação é feita em graus distintos, posicionando-se o último em menor grau, uma vez que o Sistema Interamericano ainda não enfrentou esta problemática de forma tão expressiva como fizeram os Estados Unidos.
} 
Anthony Lewis já constatava que os Estados Unidos divergem de quase todos os países ocidentais no que tange a proteção preferencial da liberdade de expressão (preferred position), inclusive protegendo os discursos odiosos. ${ }^{99}$ Porém, este direito fundamental não constava da Carta de 1787, vindo a ser garantido apenas com a criação da Primeira Emenda à Constituição, conhecida como Bill of Rights, ${ }^{100}$ em 1791, cujo texto dispõe:

O Congresso não editará leis estabelecendo uma religião oficial ou proibindo o livre exercício religioso; ou cerceando a liberdade de expressão ou de imprensa; ou o direito das pessoas de se reunirem pacificamente, e de peticionar ao governo para reparação de danos. ${ }^{101}$ (Tradução livre)

Apesar de concebida ao final do século XVIII, a efetiva proteção da garantia constitucional da liberdade de expressão iniciou-se apenas com o fim da Primeira Guerra Mundial, no julgamento do caso Stromberg Vs. California pela Suprema Corte dos Estados Unidos. ${ }^{102}$ A partir deste momento, iniciou-se o processo de construção da posição jurisprudencial estadunidense quanto a este direito, o que culminou no fortalecimento do mesmo ao longo dos anos.

Atualmente, por meio de uma jurisprudência sólida e dominante, oriunda de decisões proferidas pela Suprema Corte, a liberdade de

\footnotetext{
${ }^{99}$ LEWIS, Anthony. Liberdade Para as Ideias que Odiamos: Uma Biografia da Primeira Emenda à Constituição Americana. São Paulo: Aracati, 2011. p. ix.

${ }^{100}$ Bill of Rights é o nome dado ao conjunto das dez primeiras emendas à Constituição dos Estados Unidos, com aplicação inicial estrita para proteção dos cidadãos contra violações cometidas pelo governo federal. Apenas com o desenvolvimento da teoria da "incorporação" tais direitos foram estendidos para a proteção contra os Estados da federação.

FISS, Owen. A Ironia da Liberdade de Expressão: Estado, Regulação e Diversidade na Esfera Pública. Rio de Janeiro: Renovar, 2005. p. 20.

${ }^{101}$ Texto Original: "Congress shall make no law respecting an establishment of religion, or prohibiting the free exercise thereof; or abridging the freedom of speech, or of the press; or the right of the people peaceably to assemble, and to petition the government for a redress of grievances.”. Interessante ressaltar que, além da garantia da liberdade de expressão, a Primeira Emenda também estabeleceu a liberdade religiosa, a separação entre Igreja e Estado, o direito de reunião pacífica e o direito de petição.

FISS, Owen. A Ironia da Liberdade de Expressão: Estado, Regulação e Diversidade na Esfera Pública. Rio de Janeiro: Renovar, 2005. p. 20.

${ }^{102}$ LEWIS, Anthony. Liberdade Para as Ideias que Odiamos: Uma Biografia da Primeira Emenda à Constituição Americana. São Paulo: Aracati, 2011. p.58; SARMENTO, Daniel. A Liberdade de Expressão e o Problema do Hate Speech. Rio de Janeiro, 2006. Disponível em $<$ http://www.dsarmento.adv.br/content/3-publicacoes/18-a-liberdade-de-expressao-e-o-problemado-hate-speech/a-liberdade-de-expressao-e-o-problema-do-hate-speech-daniel-sarmento.pdf $>$.

Acesso em: 12 mar. 2018.
} 
expressão é considerada um direito prioritário dentro do sistema constitucional americano, prevalecendo sob demais direitos, como a honra, dignidade e igualdade. ${ }^{103}$ Esta preferência estaria respaldada pelos fundamentos filosóficos conferidos a esta liberdade, dentre eles, a descoberta da verdade, obtenção da autossatisfação individual, a garantia de participação efetiva na democracia e, por fim, na tendência da sociedade norte-americana de suspeitar do Estado. ${ }^{104}$

Sendo assim, a ordem constitucional dos Estados Unidos desenvolveu-se respaldada nos direitos fundamentais de primeira geração. Embora a evolução histórica desses direitos tenha ocorrido efetivamente a partir da $13^{\mathrm{a}}$ Emenda, a posição estadunidense ainda atribui maior peso à liberdade de expressão do que aos "direitos sociais". ${ }^{105}$ Desta forma, desenvolveu-se o entendimento de que os Estados Unidos reconhecem e protegem os direitos à expressão de forma muito mais ampla do que as demais democracias liberais. Como exemplo há o fato de que a maioria destas nações ratificou internamente a Convenção Internacional sobre a Eliminação de Todas as Formas de Discriminação Racial, ${ }^{106}$ enquanto os Estados Unidos, embora tenham participado na criação da mesma, nunca ratificaram seu art. $4^{\circ}$, por acreditarem que este violaria os direitos assegurados pela Primeira Emenda. ${ }^{107}$

\footnotetext{
${ }^{103}$ BRUGGER, Winfried. Proibição ou proteção do discurso do ódio?: algumas observações sobre o direito alemão e o americano. Brasília: Instituto Brasiliense de Direito Público, ano 4, janeiro-março, 2007. p. 118.

${ }_{104}$ CHEQUER, Cláudio. A Liberdade de Expressão como Direito Fundamental Preferencial Prima Facie: (análise crítica e proposta de revisão ao padrão jurisprudencial brasileiro). Rio de Janeiro: Lumen Juris, 2011.p. 97.

${ }^{105}$ SILVA, Priscilla Regina da. Os Limites Sagrados da Liberdade: uma análise do discurso de ódio contrarreligioso. Rio de Janeiro. Março de 2017. Dissertação em Pós-Graduação em Direito PUC-Rio. p.70.

${ }^{106}$ Convenção Internacional sobre Direitos Humanos que obriga as nações signatárias a proibir discursos que incitem ao ódio racial. Dispõe o art. $4^{\circ}$ desta convenção:" Os Estados-partes condenam toda propaganda e todas as organizações que se inspirem em ideias ou teorias baseadas na superioridade de uma raça ou de um grupo de pessoas de uma certa cor ou de uma certa origem étnica ou que pretendam justificar ou encorajar qualquer forma de ódio e de discriminação raciais, e comprometem-se a adotar imediatamente medidas positivas destinadas a eliminar qualquer incitação a uma tal discriminação, ou quaisquer atos de discriminação com este objetivo (...)".

107 FOLLON Jr., Richard H.. The Dynamic Constitution: An Introduction to American Constitutional Law and Practice. $2^{\mathrm{a}}$ ed. Nova York: Cambridge University Press, 2013. p. 43.
} 
Contudo, apesar da posição preferencial prima facie da liberdade de expressão já estar consolidada, a mesma não é vista como absoluta, atribuindo a ela apenas uma posição relativa mais forte ou de maior eficácia no momento de ponderação de valores e interesses em conflito em dado caso concreto. ${ }^{108}$ Como consequência, há determinados discursos ou opiniões consideradas fora do âmbito de proteção da Primeira Emenda, como o ato falso de gritar "fogo" em local fechado, a criação e reprodução de obscenidade e a incitação direta à violência. ${ }^{109}$

Dentro destas restrições, há o conceito de fighting words, ${ }^{110}$ entendidas como palavras que incitam violência, e true treaths, consideradas como verdadeiras ameaças. Ambas são exemplos de limitação à liberdade de expressão, pois podem culminar em um ato ilegal de violência a um indivíduo ou a uma coletividade. ${ }^{111}$ Isto ocorre em razão da diferenciação, feita pela doutrina e jurisprudência dos Estados Unidos, entre discurso e ato, uma vez que ideias expressas abstratamente nem sempre culminam em ações - a restrição da palavra só incide na iminência de ato violento relacionado àquela expressão proferida - clear and presente danger [perigo claro e iminente]. ${ }^{112}$

\footnotetext{
${ }^{108}$ Sob este entendimento, a Liberdade de expressão é vista apenas como um direito fundamental preferencial prima facia, não tendo força como direito absoluto. Ibid. p. 97-98.

${ }^{109}$ SARMENTO, Daniel. A Liberdade de Expressão e o Problema do Hate Speech. Rio de Janeiro, 2006. Disponível em <http://www.dsarmento.adv.br/content/3-publicacoes/18-a-liberdade-deexpressao-e-o-problema-do-hate-speech/a-liberdade-de-expressao-e-o-problema-do-hate-speechdaniel-sarmento.pdf $>$. Acesso em: 12 mar. 2018.

Schenck Vs. United States, 249 U.S. 47 (1919). Nas palavras de Justice Holmes: “(...) the character of every act depends upon the circumstances in which it is done. The most stringent protection of free speech would not protect a man in falsely shouting fire in a theatre and causing a panic. The question in every case is whether the words used are used in such circumstances and are of such a nature as to create a clear and present danger that they will bring about the substantive evils that Congress has a right to prevent".

${ }^{110}$ A doutrina das fighting words foi desenvolvida pela Suprema Corte dos Estados Unidos no caso Chaplinsky Vs. New Hampshire (315 U.S. 568 (1942)). SARMENTO, Daniel. A Liberdade de Expressão e o Problema do Hate Speech. Rio de Janeiro, 2006. Disponível em $<$ http://www.dsarmento.adv.br/content/3-publicacoes/18-a-liberdade-de-expressao-e-o-problemado-hate-speech/a-liberdade-de-expressao-e-o-problema-do-hate-speech-daniel-sarmento.pdf $>$.

Acesso em: 12 mar. 2018.

${ }^{111}$ SILVA, Priscilla Regina da. Os Limites Sagrados da Liberdade: uma análise do discurso de ódio contrarreligioso. Rio de Janeiro. Março de 2017. Dissertação em Pós-Graduação em Direito PUC-Rio. p.71.

${ }^{112}$ Ibid. p. 71 .
} 
Porém, no contexto norte-americano, estas restrições não ocorrem com o intuito de proteção do direito das vítimas, mas para a garantia de manutenção da ordem e da paz pública. ${ }^{113}$ A Suprema Corte NorteAmericana, no julgamento do caso Chaplinsky Vs. New Hampshire, sustentou que as fighting words não integram parte essencial da exposição de ideias e, desta forma, qualquer benefício que possa ser derivado delas é claramente superado pelo interesse social na salvaguarda da ordem e moralidade. ${ }^{114}$ Todavia, não existem parâmetros a esta limitação da liberdade de expressão, e, deste modo, a análise é sempre casuística, de acordo com os fatos envolvidos.

Desta forma, diante da ausência de parâmetros pré-existentes a respeito da hipótese do hate speech, a Suprema Corte desenvolveu o posicionamento jurisprudencial ao longo dos anos. $\mathrm{O}$ primeiro caso relevante envolvendo esta problemática foi julgado em 1952 pela Corte, conhecido como Beauharnais VS. Illinois, ${ }^{115}$ onde discutia-se a alegação de um indivíduo de que sua condenação criminal pelo tribunal estadual, com base em estatuto local, ${ }^{116}$ violou seu direito à liberdade de expressão e de imprensa, assegurados pela Primeira e Décima Quarta Emendas. A condenação se deu pela distribuição de panfletos que expunham cidadãos negros ao desprezo, uma vez que Beauharnais, presidente da White Circle

\footnotetext{
113 Ibid. p. 71; SARMENTO, Daniel. A Liberdade de Expressão e o Problema do Hate Speech. Rio de Janeiro, 2006. Disponível em <http://www.dsarmento.adv.br/content/3-publicacoes/18-aliberdade-de-expressao-e-o-problema-do-hate-speech/a-liberdade-de-expressao-e-o-problema-dohate-speech-daniel-sarmento.pdf $>$. Acesso em: 14 mar. 2018.

114 WEINSTEIN, James. Extreme Speech, Public Order, and Democracy: Lessons from the Masses. In: HARE, Ivan; WEINSTEIN, James (editors). Extreme Speech and Democracy. New York: Oxford University Press, 2009. p. 36; Chaplinsky Vs. New Hampshire 315 US 568, 569 (1942).

115 Beauharnais Vs. Illinois 343 US 250 (1952). Disponível em $<$ https://www.oyez.org/cases/1940-1955/343us250>. Acesso em: 14 mar. 2018.

116 Trata-se da violação do Ill.Rev.Stat., 1949, c. $38, \S 471$ (§ 224a of Division 1 of the Illinois Criminal Code), que tornava crime, para qualquer pessoa, firma ou sociedade, a fabricação, venda ou oferta para venda, anúncio, publicação, apresentação ou exibição, em locais públicos, de qualquer litografia, imagem, peça de teatro, filme ou publicações que retratem a depravação, a criminalidade, a falta de castidade ou a falta de virtude de determinada classe de cidadãos, de qualquer raça, cor, credo ou religião, expondo cidadãos de qualquer raça, cor, credo ou religião ao desprezo, escárnio ou descrédito (...). (Tradução livre). Beauharnais Vs. Illinois 343 US 250 (1952). Disponível em <https://www.oyez.org/cases/1940-1955/343us250>. Acesso em: 14 mar. 2018.
} 
League of America, convocava cidadãos brancos de Chicago a unir-se contra negros, de forma a evitar a miscigenação de raças, além de acusa-los de serem os responsáveis por crimes diversos, como invasão de propriedade, assédio, roubos e distribuição de drogas. ${ }^{117}$

A Suprema Corte realizou a análise quanto a constitucionalidade da referida lei estadual de Illinois, posicionando-se pela conformidade desta com a garantia da liberdade de expressão, de forma a manter a condenação. Justice Frankfurter, responsável pela redação da decisão, sustentou que a lei em questão era destinada para um "mal definido", redigida de acordo com a história e prática de Illinois, ${ }^{118}$ acostumada com uma série de crimes contra a população negra. Para ele, ofensas dirigidas pessoalmente para alvo específico não integram a parte essencial da exposição de ideias, possuindo valor social reduzido na busca da verdade. ${ }^{119}$ Por fim, utilizou o conceito de group libel (difamação de grupo) para sustentar que, se ofensas destinadas a particulares podem ser sancionadas criminalmente, apesar da existência da Primeira Emenda, o equivalente deveria ser aplicado à ofensas perpetradas contra grupos ou coletividade. ${ }^{120}$

\footnotetext{
${ }^{117}$ Parte da citação original do acusado: "If persuasion and the need to prevent the white race from becoming mongrelized by the negro will not unite us, then the aggressions, rapes, robberies, knives, guns and marijuana of the negro, surely will.". Beauharnais Vs. Illinois 343 US 250 (1952). Disponível em <https:/www.oyez.org/cases/1940-1955/343us250>. Acesso em: 14 mar. 2018.

118 Texto original: "It is a law specifically directed at a defined evil, its language drawing from history and practice in Illinois and in more than a score of other jurisdictions a meaning confirmed by the Supreme Court of that State in upholding this conviction. We do not, therefore, parse the statute as grammarians, or treat it as an abstract exercise in lexicography. We read it in the animating context of well-defined usage". Beauharnais Vs. Illinois 343 US 250 (1952). Disponível em <https:/www.oyez.org/cases/1940-1955/343us250>. Acesso em: 14 mar. 2018.

119 Texto original: "There are certain well defined and narrowly limited classes of speech the prevention and punishment of which has never been thought to raise any Constitutional problem. These include the lewd and obscene, the profane, the libelous, and the insulting or 'fighting' words -- those which, by their very utterance, inflict injury or tend to incite an immediate breach of the peace. It has been well observed that such utterances are no essential part of any exposition of ideas, and are of such slight social value as a step to truth that any benefit that may be derived from them is clearly outweighed by the social interest in order and morality". Beauharnais Vs. Illinois 343 US 250 (1952). Disponível em <https://www.oyez.org/cases/1940-1955/343us250>. Acesso em: 14 mar. 2018.

${ }^{120}$ Texto original: "But if an utterance directed at an individual may be the object of criminal sanctions, we cannot deny to a State power to punish the same utterance directed at a defined group unless we can say that this a willful and purposeless restriction unrelated to the peace and wellbeing of the State.". Beauharnais Vs. Illinois 343 US 250 (1952). Disponível em $<$ https://www.oyez.org/cases/1940-1955/343us250>. Acesso em: 14 mar. 2018
} 
Apesar de ausência de reforma desta decisão, a análise posterior da jurisprudência americana sobre liberdade de expressão, especialmente quanto à extensão da proteção da Primeira Emenda em relação a declarações difamatórias sobre questões de interesse público, demonstra o contrário. ${ }^{121}$ Este cenário é claro no julgamento do caso Brandenburg vs. Ohio, ${ }^{122}$ em 1969, pela Suprema Corte. O líder do Ku Klux Klan organizou um comício do movimento em uma fazenda de Hamilton County, no qual convidou um repórter para realizar a transmissão do evento em escala local e nacional. A filmagem trazia 12 (doze) figuras encapuzadas, que ostentavam armas de fogo e bíblias, ao redor de cruz de madeira em chamas. Além dos participantes do clã e do jornalista responsável pela filmagem, ninguém estava presente.

Apesar de a maioria das palavras do filme serem incompreensíveis, frases diversas trazem a depreciação de negros e judeus. Em uma de suas falas, Brandenburg sustentou que, caso o Presidente, o Congresso e a Suprema Corte continuassem a suprimir os brancos, a raça caucasiana, o $K u$ Klux Klan poderia agir em vingança. Em fragmento diverso de filmagem, o líder defendia a volta dos negros para a África e dos judeus para Israel. ${ }^{123}$

Diante dos fatos transmitidos, o Tribunal do Estado de Ohio proferiu decisão condenatória contra Brandenburg por apologia ao crime (criminal syndicalism), com base no Estatuto Criminal de Ohio, que determinava a

SARMENTO, Daniel. A Liberdade de Expressão e o Problema do Hate Speech. Rio de Janeiro, 2006. Disponível em <http://www.dsarmento.adv.br/content/3-publicacoes/18-a-liberdade-deexpressao-e-o-problema-do-hate-speech/a-liberdade-de-expressao-e-o-problema-do-hate-speechdaniel-sarmento.pdf>. Acesso em: 14 mar. 2018.

${ }^{121}$ WEINSTEIN, James. An Overview of American Free Speech Doctrine and its Application to Extreme Speech. In: HARE, Ivan; WEINSTEIN, James (editors). Extreme Speech and Democracy. New York: Oxford University Press, 2009. p. 87-88; WEINSTEIN, James. Extreme Speech, Public Order, and Democracy: Lessons from The Masses. In: HARE, Ivan; WEINSTEIN, James (editors). Extreme Speech and Democracy. New York: Oxford University Press, 2009. p. 23-61.

122 Brandenburg VS. Ohio 395 U.S. $444 \quad$ (1969). Disponível em: $<$ https://www.oyez.org/cases/1968/492>. Acesso em: 15 mar. 2018.

${ }^{123} \mathrm{O}$ discurso original de Brandenburg continha as seguintes palavras: "We're not a revengent organization, but if our President, our Congress, our Supreme Court, continues to suppress the white, Caucasian race, it's possible that there might have to be some revengeance taken." e "Personally, I believe the nigger should be returned to Africa, the Jew returned to Israel.". Brandenburg VS. Ohio 395 U.S. 444 (1969). Disponível em: $<$ https://www.oyez.org/cases/1968/492>. Acesso em: 15 mar. 2018. 
punição de pessoas que defendiam ou ensinavam a violência como meio de realizar reformas industriais ou políticas ou que exibissem ou publicassem qualquer livro ou papel que contivesse essa defesa. Julgamento posterior da Suprema Corte reformou a decisão do tribunal estadual por entender que a o estatuto que justificava a condenação era inconstitucional por violação da Primeira Emenda. Alegou a corte haver clara diferença entre a defesa abstrata de ideias racistas da iminente realização de atos violentos enquanto a primeira não pode ser limitada pelo Estado, em razão da garantia da liberdade de expressão e de imprensa, a segunda é passível de restrição, por não se enquadrar no âmbito de proteção da Primeira Emenda. Nas palavras da corte:

A liberdade de expressão e de imprensa não permitem que o Estado proíba a defesa do uso da força ou a violação da lei, exceto no caso de esta defesa estar diretamente relacionada com incitar ou produzir uma ação ilegal, e é provável que incite ou produza estes atos (tradução livre). ${ }^{124}$

Desta forma, a Corte desenvolveu precedente a favor do direito de expressão de ideias em abstrato, mesmo que estas tragam pensamentos odiosos e desprezíveis, desde que atitudes concretas e iminentes sejam inexistentes.

Alguns anos após o caso de Ohio, o judiciário norte-americano deparou-se com novo caso similar, National Socialist Party of America Vs. Village of Skokie. ${ }^{125} \mathrm{O}$ Partido Nacional Socialista da América pretendeu realizar passeata de neonazistas em Skokie, município no subúrbio de Chicago, conhecido por possuir mais de $50 \%$ da população composta por judeus, inclusive sobreviventes do Holocausto. A ideia inicial era a marcha dos membros do partido com o uso de uniforme e o símbolo da suástica em

\footnotetext{
124 Texto original: "Freedoms of speech and press do not permit a State to forbid advocacy of the use of force or of law violation except where such advocacy is directed to inciting or producing imminent lawless action and is likely to incite or produce such action." Brandenburg Vs. Ohio 395 U.S. 444 (1969). Disponível em: <https://www.oyez.org/cases/1968/492>. Acesso em: 15 mar. 2018.

${ }^{125}$ National Socialist Party of America v. Village of Skokie 432 U.S. 43 (1977). Disponível em: $<$ https://supreme.justia.com/cases/federal/us/432/43/>. Acesso em: 16 mar. 2018.
} 
bandeiras, assim como a distribuição de panfletos que incitaria ou promoveriam ódio contra judeus.

Diante da iminência da manifestação, o município tentou, de diversas formas, impedir a realização do movimento. Inicialmente, ajuizaram ação, em instância estadual, julgada improcedente pela Suprema Corte de Illinois sob a justificativa de que a mera realização da passeata e exposição de símbolos não qualificam o perigo de dano ou violência iminentes, de maneira a desconfigurar a possibilidade de restrição do discurso. Com a improcedência do pedido inicial, o município optou por editar norma local que dificultava a realização do movimento naquela localidade. Todavia, o Circuit Court de Skokie alegou que estas normativas violavam o direito fundamental de expressão, consagrado na Primeira Emenda à Constituição, declarando-as inconstitucionais. O caso, entretanto, não alcançou a instância máxima da Suprema Corte, uma vez que a organização do partido optou pela realização da passeata em local diverso.

A partir destas exposições, entende-se que a jurisprudência estadunidense optou pela inconstitucionalidade de restrições ao discurso de ódio quanto estas envolvem limitações ao discurso político justificadas pelo ponto de vista do sujeito. A partir desta premissa, a propagação de ideias racistas radicais ou hediondas não poderia ser limitada ou restringida, uma vez que o Estado teria a obrigação de adotar uma postura de total neutralidade diante destas expressões, para a garantia da democracia, desde que não tragam perigo de reação violenta iminente (fighting words). ${ }^{126}$ Ainda que o conteúdo das ideias se relacione à incitação de conduta ilegal, o pressuposto inicial é a não proibição de sua utilização, caso não haja a possibilidade de realização desta ação. ${ }^{127}$

\footnotetext{
${ }^{126}$ SARMENTO, Daniel. A Liberdade de Expressão e o Problema do Hate Speech. Rio de Janeiro, 2006. Disponível em <http://www.dsarmento.adv.br/content/3-publicacoes/18-a-liberdade-deexpressao-e-o-problema-do-hate-speech/a-liberdade-de-expressao-e-o-problema-do-hate-speechdaniel-sarmento.pdf>. Acesso em: 16 mar. 2018.

${ }^{127}$ MEYER-PFLUG, Samantha Ribeiro. Liberdade de expressão e discurso do ódio. São Paulo: RT, 2009. p. 141-142.
} 
A afirmação de que palavras, por si só, infligem dano é claramente rejeitada no cenário constitucional norte-americano. No caso de Skokie, a intenção do município em proibir a realização da passeata não se baseava na expressão per si, mas em razão de seus efeitos gerados nos cidadãos daquela localidade. ${ }^{128}$

Em R.A.V VS. City of St. Paul, ${ }^{129}$ 1992, um grupo de indivíduos invadiu o território de uma família de afrodescendentes e, no local, ateou fogo a uma cruz. Como consequência, foram considerados culpados em primeira instância pela Suprema Corte de Minnesota, por violação da legislação local, que criou o bias motivated crime (crime motivado por preconceito), que condenava o ato de colocar em propriedade pública ou privada um símbolo, objeto, palavra, caracterização ou grafite, sabendo ou com razoáveis motivos para saber, que tal atitude causaria raiva, medo ou ressentimento em outros, com base em raça, cor, credo, religião ou gênero. ${ }^{130}$ Em âmbito estadual, o tribunal considerou a lei compatível com as determinações da Primeira Emenda, sendo restritiva ao ponto de apenas restringir as fighting words - condutas que, por si só, infligem dano ou tenham a intenção de incitar a violência imediata.

A Suprema Corte dos Estados Unidos reverteu a decisão de Minnesota, com base na inconstitucionalidade da lei estadual. A Corte constatou que seus julgados foram responsáveis pela criação de uma hierarquia constitucional de proteção da liberdade de expressão - o discurso político ocuparia a posição mais alta e protegida, enquanto o discurso comercial tenderia a menor proteção e, por fim, a obscenidade e as fighting

128 SILVA, Priscilla Regina da. Os Limites Sagrados da Liberdade: uma análise do discurso de ódio contrarreligioso. Rio de Janeiro. Março de 2017. Dissertação em Pós-Graduação em Direito PUC-Rio. p. 75.

${ }^{129}$ R.A.V. $\quad$ VS. St. $\quad$ Paul $505 \quad$ U.S. $377 \quad$ (1992). Disponível em $<$ https://supreme.justia.com/cases/federal/us/505/377/case.html>. Acesso em: 16 mar. 2018.

130 Texto Original de St. Paul Bias-Motivated Crime Ordinance, St. Paul, Minn., Legis. Code $\S$ 292.02: "Whoever places on public or private property a symbol, object, appellation, characterization or graffiti, including, but not limited to, a burning cross or Nazi swastika, which one knows or has reasonable grounds to know arouses anger, alarm or resentment in others on the basis of race, color, creed, religion or gender commits disorderly conduct and shall be guilty of a misdemeanor." R.A.V. Vs. St. Paul 505 U.S. 377 (1992). Disponível em: $<$ https://supreme.justia.com/cases/federal/us/505/377/case.html>. Acesso em: 16 mar. 2018. 
words receberiam a menor proteção possível. ${ }^{131}$ Desta forma, a Corte constatou a licitude de atos estatais de proibição de utilização das fighting words, porém não de forma parcial como entenderam ser o caso da lei estadual em questão, pois ela destinava-se somente a motivações baseadas em raça, cor, credo, religião ou gênero. Justice Scalia enfatizou que o Estado possui o dever de neutralidade em relação ao conteúdo das regulações, e, por esta premissa, a corte considerou que St. Paul não possuía autoridade para ser seletivo quanto as ideias que poderiam ser expressas, limitando apenas aquelas motivas por preconceito de raça, cor, credo, religião e gênero. ${ }^{132}$

Caso semelhante ocorreu em Virginia Vs. Black et. al., ${ }^{133}$ 2003. Três cidadãos americanos foram condenados em razão de lei de Virginia que tornava crime a queima de cruzes em propriedade de terceiros, em estradas ou em outros lugares públicos, com a intenção de intimidação de pessoa ou grupo - o próprio ato de queima de cruz já era, por si só, considerado evidencia suficiente da intenção de intimidar. A Suprema Corte do Estado de Virgina julgou a lei estadual inconstitucional por violação da Primeira Emenda, pois esta realizava discriminação com base no conteúdo e no ponto de vista, escolhendo apenas a queima de cruzes para a criminalização.

A Suprema Corte dos Estados Unidos, em oposição, considerou a lei constitucional, por considerar que apenas restringia o que era considerado

\footnotetext{
131 Texto Original: "First Amendment decisions have created a rough hierarchy in the constitutional protection of speech. Core political speech occupies the highest, most protected position; commercial speech and nonobscene, sexually explicit speech are regarded as a sort of second-class expression; obscenity and fighting words receive the least protection of all.". R.A.V.
U.S. $\quad 377$
(1992).

Vs. St. Paul 505

Disponível

em

<https://supreme.justia.com/cases/federal/us/505/377/case.html>. Acesso em: 16 mar. 2018.

132 "St. Paul has no such authority to license one side of a debate to fight freestyle, while requiring the other to follow Marquis of Queensberry rules. What we have here, it must be emphasized, is not a prohibition of fighting words that are directed at certain persons or groups (which would be facially valid if it met the requirements of the Equal Protection Clause); but rather, a prohibition of fighting words that contain (as the Minnesota Supreme Court repeatedly emphasized) messages of "biasmotivated" hatred and in particular, as applied to this case, messages "based on virulent notions of racial supremacy.". R.A.V. Vs. St. Paul 505 U.S. 377 (1992). Disponível em $<$ https://supreme.justia.com/cases/federal/us/505/377/case.html>. Acesso em: 16 mar. 2018.

${ }^{133}$ Virginia Vs. Black et. al.. Disponível em: <https://www.oyez.org/cases/2002/01-1107>. Acesso em: 16 mar. 2018.
} 
como ameaça verdadeira (a queima de cruzes), sem distinção de conteúdo, como ocorrera no caso R.A.V Vs. City of St. Paul. A lei de Virginia não criminalizava a utilização de palavras, mas apenas atos concretos de ameaça (true threat) ou incitação à violência (fighting words), sem realizar distinção fundamentada em raça, cor, credo, religião ou gênero, passível de aplicação para todos os casos em abstrato. Todavia, o fragmento da lei que determinava a queima de cruzes como evidencia suficiente para determinar intenção de intimidação foi considerado inconstitucional. A Corte considerou que, por mais que tal atitude, quando realizada com o propósito intimidador, possa ser criminalizada, a queima de cruzes sem esta intenção, como o discurso político, é protegida pela liberdade de expressão e estaria prejudicada pela lei estadual. ${ }^{134}$

Em 2011, a Suprema Corte julgou caso Snyder Vs. Phelps ${ }^{135}$ envolvendo membros da Igreja Batista de Westboro, que pregavam a crença de que Deus odeia os Estados Unidos por sua tolerância à homossexualidade, particularmente dentro das forças armadas. Com o intuito de difundir crenças, Fred Phelps, fundador da Igreja, e outros membros realizavam, frequentemente, piquetes em funerais de militares norte-americanos.

Em 2006, participantes da Igreja Batista de Westboro viajaram até Maryland para realizar um piquete no funeral de Matthew Snyder, militar homossexual morto à serviço no Iraque. A manifestação ocorreu em terra pública, em concordância com as determinações de leis e polícia locais, portando cartazes que traziam frases como "Agradeça a Deus pelos

\footnotetext{
134 Justice O'Connor: "The act of burning a cross may mean that a person is engaging in constitutionally proscribable intimidation, or it may mean only that the person is engaged in core political speech. The prima facie evidence provision blurs the line between these meanings, ignoring all of the contextual factors that are necessary to decide whether a particular cross burning is intended to intimidate. The First Amendment does not permit such a shortcut.". Virginia Vs. Black et. al.,. Disponível em: <https://www.oyez.org/cases/2002/01-1107>. Acesso em: 16 mar. 2018.

${ }^{135}$ Snyder Vs. Phelps 562 U.S. 443 (2011). Disponível em <https://www.oyez.org/cases/2010/09751>. Acesso em: 16 mar. 2018.
} 
soldados mortos", "Padres estupram garotos", "A América está perdida", “Obrigada, Deus, pelo 11/09” e "Não rezem pelos Estados Unidos”.

Albert Snyder, pai do soldado, apesar de ter reconhecido a movimentação nas proximidades do funeral, não conseguiu ler a mensagem nos cartazes. Posteriormente, tomou conhecimento deste conteúdo através de notícias sobre o protesto, o que levou Snyder a processar Phelps, membros participantes e a Igreja, com base no enorme sofrimento emocional que lhe foi infligido.

As decisões proferidas pelos tribunais foram conflitantes: em primeira instancia, o réu foi condenado ao pagamento de milhões de dólares a título de indenização, o que foi alterado em recurso por violação da Primeira Emenda. A Suprema Corte dos Estados Unidos sustentou de que o caso envolvia questões de interesse público, não privado, e, por isso, o piquete estaria protegido pela liberdade de expressão. A Corte sustentou que, mesmo que o protesto estivesse diretamente relacionado aos Snyder, o conteúdo dos cartazes relaciona-se com questões gerais de interesse para a sociedade como um todo - a conduta política e moral dos Estados Unidos e de seus cidadãos, o destino da nação, a homossexualidade militar e os escândalos envolvendo o clero católico. Desta forma, Phelps e os demais estariam apenas externando questões de interesse público amplo em propriedade pública, protegidos pela Primeira Emenda. ${ }^{136}$

Interessante ressaltar que, em todos os julgados expostos, não foi dada nenhuma atenção especial ao princípio da igualdade, consagrado pela Décima Quarta Emenda, em benefício da liberdade de expressão. A

\footnotetext{
136 "The "content" of Westboro's signs plainly relates to broad issues of interest to society at large, rather than matters of "purely private concern." The placards read "God Hates the USA/Thank God for $9 / 11$," "America is Doomed," "Don't Pray for the USA," "Thank God for IEDs," "Fag Troops," "Semper Fi Fags," "God Hates Fags," "Maryland Taliban," "Fags Doom Nations," "Not Blessed Just Cursed," "Thank God for Dead Soldiers," "Pope in Hell," "Priests Rape Boys," "You're Going to Hell," and "God Hates You." While these messages may fall short of refined social or political commentary, the issues they highlight - the political and moral conduct of the United States and its citizens, the fate of our Nation, homosexuality in the military, and scandals involving the Catholic clergy - are matters of public import.". Snyder Vs. Phelps 562 U.S. 443 (2011). Disponível em <https://www.oyez.org/cases/2010/09-751>. Acesso em: 16 mar. 2018.
} 
proteção desta garantia pelos norte-americanos, de prevalência prima facie, pode ser explicada a partir de algumas considerações, levantadas por Daniel Sarmento. ${ }^{137}$ A cultura e o constitucionalismo norte-americanos consagram maior valorização da liberdade de expressão frente ao princípio da igualdade, por vezes, ignorando a força silenciadora que discursos opressivos de intolerantes podem causar em seus alvos. Ainda há a subsistência do pensamento de que princípios constitucionais são aplicados apenas de forma vertical, com a vinculação apenas do Estado, através da ideia de State Action - esta doutrina ressalta que ideias racistas, preconceituosas e intolerantes violam a Constituição quando praticadas por membros do Estado, mas protegidas pela liberdade de expressão quando praticadas por particulares. ${ }^{138}$

O sistema adotado pelos Estados Unidos defende a liberdade de expressão em ampla escala, de forma a optar apenas por restrições em casos de iminente e clara incitação à violência ou ameaça real, desde que ausentes limitações baseadas no ponto de vista e conteúdo. O Estado norteamericano deve agir de forma neutra perante os discursos, de maneira a possibilitar a divulgação de ideias variadas, especialmente aquelas ligadas ao interesse público. O discurso de ódio, quando mantido no mundo das ideias, é protegido pela Primeira Emenda.

\subsubsection{Sistema Interamericano de Direitos Humanos}

Os países integrantes da Organização dos Estados Americanos (OEA) são submetidos e responsabilizados pelas condições dos direitos humanos em seus territórios pelo Sistema Interamericano de Direitos Humanos, composto pela Comissão Interamericana de Direitos Humanos

\footnotetext{
${ }^{137}$ SARMENTO, Daniel. A Liberdade de Expressão e o Problema do Hate Speech. Rio de Janeiro, 2006. Disponível em <http://www.dsarmento.adv.br/content/3-publicacoes/18-a-liberdade-deexpressao-e-o-problema-do-hate-speech/a-liberdade-de-expressao-e-o-problema-do-hate-speechdaniel-sarmento.pdf>. Acesso em: 16 mar. 2018.

138 Ibid.
} 
(CIDH) e a Corte Interamericana de Direitos Humanos (Corte IDH) - a primeira é órgão consultivo, enquanto a segunda é judicial. ${ }^{139}$

A Corte IDH foi criada pela Convenção Americana de Direitos Humanos (CADH - Pacto de São José da Costa Rica, internalizado no ordenamento jurídico brasileiro através do Decreto $n^{0}$ 678/1992), responsável pela interpretação e aplicação da $\mathrm{CADH}$ apenas para os países que aceitaram sua jurisdição contenciosa. ${ }^{140} \mathrm{O}$ sistema interamericano possui o objetivo de ser suplementar e complementar aos sistemas nacionais, que possuem responsabilidade primária na proteção e reforço dos direitos individuais e coletivos. Além da $\mathrm{CADH}$, o sistema é integrado, desde sua criação, também pela Declaração Americana dos Direitos e Deveres do Homem (1948). ${ }^{141}$

Dentro do Sistema Interamericano de Direitos Humanos, ainda não há posicionamento jurisprudencial quanto ao tema do hate speech, porém, ambos os órgãos integrantes deste Sistema já se posicionaram sobre o tema em âmbito consultivo. Desta forma, a liberdade de pensamento e de expressão são previstas pela $\mathrm{CADH}$, art. 13, o que inclui a liberdade de buscar, receber e difundir informações e ideias de toda a natureza, com expressa vedação da censura prévia. A princípio, há a presunção de proteção de todas as formas de discurso, independentemente de conteúdo e da maior ou menos aceitação social e estatal destas ideias. ${ }^{142}$ Esta presunção de proteção de todo discurso expressivo se explica pela obrigação primária de neutralidade dos Estados frente aos conteúdos, baseado na necessidade

\footnotetext{
139 International Justice Resource Center. Preventing and Remedying Human Rights Violations through the International Framework: Advocacy before the Inter-American System - Manual for Attorneys and Advocates. Disponível em <http://ijrcenter.org/wpcontent/uploads/2009/12/Manual-for-Attorneys-and-Advocates.pdf $>$. Acesso em: 17 mar. 2018.

${ }^{140}$ Ibid.

${ }^{141}$ Ibid.

${ }^{142}$ Comissão Interamericana De Direitos Humanos. Informe Anual 2012. Informe de la Relatóría para la Libertad de Expresión. Disponível em $<$ http://www.oas.org/es/cidh/expresion/docs/informes/anuales/informe\%20anual\%202012.pdf>. Acesso em 17 mar. 2018. p. 208.
} 
de garantia de que não existam pessoas, grupos, ideias ou meios de expressão excluídos, a priori, do debate público. ${ }^{143}$ Nesse sentido:

(...) a Corte Interamericana reiterou que a liberdade de expressão deve ser assegurada não só em relação a divulgação de ideias e informações recebidas favoravelmente pelas pessoas ou consideradas inofensivas ou indiferentes, mas também em relação àquelas que ofendem e colidem com as ideias majoritárias. Assim exige o pluralismo a tolerância e o espírito de abertura, sem os quais não há sociedade democrática. ${ }^{144}$ (Tradução livre)

A Convenção Americana também determina restrições a essa liberdade, orientando pela existência de regulação proibitiva de toda propaganda a favor da guerra, apologia ao ódio nacional, racial ou religioso que constitua incitação à discriminação, à hostilidade, ao crime ou à violência. Neste contexto, em concordância com a doutrina e jurisprudencial internacional, a Comissão Interamericana tem indicado que a imposição de sanções pelo abuso da liberdade de expressão, em razão de incitação à violência, deve ter como pressuposto a prova concreta, certa e objetiva de que a pessoa não estava simplesmente em seu direito de manifestar uma opinião, por mais perturbadora, injusta ou discriminatória que tenha sito, mas tenha tido a intenção evidente de cometer um crime. ${ }^{145}$

Segundo orientações da CIDH, o art. 13, inciso 2, da Convenção Americana prevê três condições básicas que devem ser seguidas para que a restrição à liberdade de expressão seja aceita: (1) a restrição deve, obrigatoriamente, estar taxativamente definida em lei formal e material de forma clara e prévia; (2) a limitação deve basear-se nos objetivos definidos pela $\mathrm{CADH}$; (3) a restrição deve ser necessária em uma sociedade

\footnotetext{
${ }^{143}$ Ibid.

${ }^{144}$ Texto original: "En este orden de ideas, la Corte Interamericana ha reiterado que la libertad de expresión debe garantizarse no sólo en cuanto a la difusión de ideas e informaciones recibidas favorablemente o consideradas inofensivas o indiferentes, sino también en cuanto a las que ofenden y chocan. Así lo exigen el pluralismo, la tolerancia y el espíritu de apertura, sin los cuales no existe una sociedad democrática." Ibid.

${ }^{145}$ Comissão Interamericana De Direitos Humanos. Marco jurídico interamericano sobre o direito à liberdade de expressão. Relatoria Especial para a Liberdade de Expressão, 2014. Disponível em: $<$ https://www.oas.org/pt/cidh/expressao/docs/publicaciones/20140519\%20-

$\% 20$ PORT\%20Unesco\%20-

\%20Marco\%20Juridico\%20Interamericano\%20sobre\%20el\%20Derecho\%20a\%20la\%20Libertad \%20de\%20Expresion\%20adjust.pdf>. Acesso em: 17 mar. 2018. p. 20.
} 
democrática para que esta realize os seus fins. Todas as condições devem ser simultaneamente cumpridas e demonstradas para que haja legitimidade da restrição ao discurso, estabelecida por meio de responsabilidade ulterior e proporcional. Neste cenário, a Comissão considera que normas vagas ou ambíguas são incompatíveis com a $\mathrm{CADH}$, consideradas equivalentes à censura prévia, uma vez que podem ocasionar atos de total arbitrariedade ou responsabilidades desproporcionais e discriminatórias. ${ }^{146}$

A CIDH posiciona-se pela excepcionalidade das restrições à liberdade de expressão, de forma a impedir que certas pessoas, grupos, ideias ou meios de expressão fiquem de fora do debate público, essencial a um Estado Democrático. Consequentemente, defende a utilização de padrões de controle mais restritos para certas limitações, com base no tipo de discurso, estabelecendo formas de expressão que possuem nível reforçado de proteção, como o discurso político e sobre assuntos de interesse público ou aqueles que expressam parte essencial da identidade $\mathrm{e}$ dignidade da pessoa. ${ }^{147}$

Apesar de posicionamento claro da Comissão Interamericana de Direitos Humanos quanto a restrições realizadas com base no discurso de ódio, a jurisprudência sobre o caso ainda é escassa. A tendência da CIDH é de acompanhar o posicionamento dos Estados Unidos no sentido de restringir o máximo possível as limitações à liberdade de expressão, pois esta é vital para o desenvolvimento do Estado Democrático e do debate plural, com a permissão de divulgação das mais variadas formas de discurso, inclusive aqueles considerados odiosos, desde que ausente a iminência de violência ou concretude de um crime.

\subsection{Sistema europeu de combate ao discurso de ódio}

${ }^{146}$ Ibid. p. 23.
${ }^{147}$ Ibid. p. 32. 
Os países europeus, em sua maioria, protegem a liberdade de expressão em suas Constituições, todavia, esta não é defendida de forma prevalecente, uma vez que há restrições impostas a esse direito em benefício de outros. Em oposição ao cenário norte-americano, o sistema europeu de proteção à liberdade de expressão não se orienta pelo princípio da neutralidade estatal em relação ao conteúdo das ideias, visto que os países têm editado leis que criminalizam a difusão de ideias racistas e xenófobas, espécies de discurso de ódio. ${ }^{148}$

No âmbito do continente europeu, será analisado, a seguir, a posição atual da Alemanha e da Corte Europeia de Direitos Humanos sobre esta temática.

\subsubsection{Alemanha}

Há algumas razões para a escolha da Alemanha como parâmetro de tratamento do hate speech dentre os países europeus no presente trabalho. Inicialmente, o país, após o fim da Segunda Guerra Mundial, busca, a todo momento, diferenciar-se do regime nazista anterior, responsável por discursos e crimes de ódio. Por esta razão, a Constituição alemã (Grundgesetz - BL) e o Tribunal Federal Constitucional Alemão (Bundesverfassungsgericht - BVerfG) ganharam grande respeito internacional, ao ponto de suas concepções serem seguidas por grande parte dos países europeus e pelo Direito Internacional. ${ }^{149}$

As liberdades de expressão e de informação são amplamente garantidas na Constituição alemã - art. 5 (1) - ao permitir que todos tenham o direito de expressar e divulgar livremente o pensamento por via oral, por escrito e por imagem, bem como informar-se, sem impedimentos, em fontes de acesso geral. O mesmo artigo traz também a liberdade de imprensa por

\footnotetext{
${ }^{148}$ MEYER-PFLUG, Samantha Ribeiro. Liberdade de Expressão e Discurso do Ódio. São Paulo: RT, 2009. p. 149-150

149 BRUGGER, Winfried. The Treatment of Hate Speech in German Constitutional Law. Charlottesville: German Law Journal, Vol. 4, n 1 , 2003. p. 3.
} 
meio da radiodifusão e do filme, assim como bane quaisquer possibilidades de censura. A partir desta leitura, é possível entender que a liberdade de expressão é um dos direitos fundamentais amplamente protegidos pelo país, em concordância com os pressupostos de um Estado Democrático de Direito.

A jurisprudência alemã, especificamente no julgamento de Television I, II e III Cases,${ }^{150}$ determinou que o papel do Estado, frente à liberdade de expressão, não se limita apenas ao viés negativo, tendo este também a obrigação positiva na criação de legislações necessárias para corrigir o mercado de ideias e garantir a pluralidade de opiniões, proporcionando aos cidadãos o acesso aos mais variados pontos de vista $\mathrm{e}$ conteúdos. ${ }^{151}$ Além disso, o panorama constitucional entende que a liberdade de expressão é exercida e protegida nas dimensões horizontal e vertical, isto é, nas relações entre particulares e entre particulares e o Estado. ${ }^{152}$

A Corte Constitucional alemã reconheceu a extrema importância da liberdade de expressão na formação de opiniões, vitais para a autonomia do orador. Há também o reconhecimento da essencialidade da livre troca de informações e ideias entre os cidadãos para ocorrência da efetiva busca da

\footnotetext{
${ }^{150}$ KOMMERS, Donald P.; MILLER, Russel A. The Constitutional Jurisprudence of the Federal Republic of Germany. $2^{\mathrm{a}}$ ed.. Durham: Duke University Press, 1997. p. 404-410.

${ }^{151}$ SARMENTO, Daniel. A Liberdade de Expressão e o Problema do Hate Speech. Rio de Janeiro, 2006. Disponível em <http://www.dsarmento.adv.br/content/3-publicacoes/18-a-liberdade-deexpressao-e-o-problema-do-hate-speech/a-liberdade-de-expressao-e-o-problema-do-hate-speechdaniel-sarmento.pdf $>$. Acesso em: 17 mar. 2018.

152 Este entendimento foi firmado no julgamento de Lüth Case (1958), 7 BVerfGE 198. A Corte Federal Constitucional Alemã garantiu o direito de Erich Lüth de influenciar, com seu discurso, o boicote ao filme Immortal Lover, de Veit Harlan, conhecido por ter cometidos crimes de ódio durante o período nazista. Para a Corte, os tribunais inferiores deram atenção insuficiente aos motivos de Lüth, cuja preocupação central era evitar que pensamentos antissemitas fossem difundidos novamente por meio do filme, especialmente no período subsequente ao fim do regime nazista. Este caso é paradigmático no cenário alemão pelos mais variados motivos, dentre eles: (i) a decisão enfatizou a dimensão individual e social do direito à expressão; (ii) determinou que a liberdade de expressão possui viés positivo e negativo; (iii) estabeleceu que o discurso político ou de interesse público possuem maior proteção constitucional do que expressões proferidas com propósitos privados ou financeiros; (iv) solidificou o entendimento de que a Constituição Federal é a lei máxima do país; (v) firmou a orientação de que princípios constitucionais afetam todas as áreas do direito, inclusive o direito privado. KOMMERS, Donald P.; MILLER, Russel A. The Constitutional Jurisprudence of the Federal Republic of Germany. 2 $2^{\mathrm{a}}$ ed.. Durham: Duke University Press, 1997. p. 361-368.
} 
verdade, responsável pela legitimação da democracia, de forma a ajudar na tomada de decisões pelos indivíduos nas esferas pública e privada, sem necessidade de auxílio da violência física. ${ }^{153}$

Apesar desta forte proteção, não há presunção de prevalência deste direito frente a outros bens jurídicos, visto que o país, após período histórico conturbado, tende a privilegiar a igualdade, dignidade, personalidade, honra e proteção à infância, com a utilização do princípio da ponderação. ${ }^{154}$ Por esse motivo, o art. 5 (2) traz três restrições à liberdade de expressão: disposições das leis gerais, os regulamentos legais de proteção da juventude e o direito da honra pessoal.

Além disso, igualmente em razão da barbárie ocorrida durante o período nazista, o país adotou a ideia da democracia militante. Esta teoria refere-se a uma forma democrática onde o Estado é autorizado a restringir o exercício de certas liberdades em benefício de outras, visando a defesa da ordem constitucional daqueles que não aceitam ou concordam com suas regras. ${ }^{155}$ A partir desta ideia, a Alemanha adotou diversos dispositivos legais responsáveis por restringir algumas liberdades, como: a proibição de associações cuja finalidade ou atividade sejam contrárias às leis penais ou estejam orientadas contra a ordem constitucional - art. 9 (2), BL; a possibilidade de decretação de inconstitucionalidade pelo Tribunal Constitucional Federal Alemão de partidos políticos que, por meio de seus objetivos ou pelas atitudes de seus membros, tentarem prejudicar ou eliminar a ordem fundamental democrática ou pôr em perigo a República

153 BRUGGER, Winfried. Proibição ou proteção do discurso do ódio?: algumas observações sobre o direito alemão e o americano. Brasília: Instituto Brasiliense de Direito Público, ano 4, janeiro-março, 2007. p. 123-124.

154 Apesar de não estar explicitamente definido na Constituição Federal Alemã, o princípio da proporcionalidade é considerado um standard constitucional implícito. Desta forma, o Tribunal Constitucional Alemão utiliza-se de três elementos para aplicação deste princípio em caso de restrições a direitos e liberdades por ações estatais: (i) os meios utilizados pelo governo (regulação ou proibição) são adequados para promover um objetivo legítimo; (ii) não há outros meios menos restritivos e igualmente efetivos existentes para promoção do mesmo propósito; (iii) há relação adequada entre a importância do bem público a ser alcançado e a intrusão no direito protegido. BRUGGER, Winfried. The Treatment of Hate Speech in German Constitutional Law. Charlottesville: German Law Journal, Vol. 4, n 1, 2003. p. 9-10.

${ }^{155}$ KOMMERS, Donald P.; MILLER, Russel A. The Constitutional Jurisprudence of the Federal Republic of Germany. $2^{\mathrm{a}}$ ed.. Durham: Duke University Press, 1997. p. 217-218. 
Federal da Alemanha - art. 21 (2);156 a obrigatoriedade de ser leal à Constituição no exercício da liberdade de ensinar - art. 5 (3), BL; e a viabilidade da Corte Constitucional declarar a perda de certos direitos fundamentais para todos aqueles que combatem a ordem democrática ou abusarem de algumas liberdades e direitos, como a liberdade de expressão e imprensa - art. 18, BL.

Neste cenário, quando tratamos de discurso de ódio, há a constatação de que a Alemanha já promulgou diversas legislações infraconstitucionais para regular ou criminalizar esta prática na esfera penal, administrativa e civil, de forma a cumprir, ao contrário dos Estados Unidos, com as obrigações que lhe eram incumbidas por força da Convenção Internacional sobre a Eliminação de Todas as Formas de Discriminação Racial.

O capítulo 14, artigos 185 a 200, do Código Federal Penal Alemão, contêm provisões sobre a possibilidade de punição da difamação e do insulto, individuais ou coletivos. Os casos de hate speech, frequentemente, envolvem difamação coletiva de um grupo, onde seus membros possuem características que os identificam como tal, os diferenciando do resto da sociedade, como raça, etnia, religião ou gênero. Além disso, o capítulo de crimes contra a paz pública do mesmo Código, artigos 124 a 145, d, criminaliza a incitação ao ódio e violência contra grupos minoritários. Notase que as disposições alemães de direito penal estabelecem criminalização ampla do hate speech dirigido contra indivíduos e grupos, especialmente

\footnotetext{
156 Partidos políticos radicais já foram banidos duas vezes na história alemã. O primeiro a ser banido foi o partido de extrema direita Sozialistische Reichspartei (SRP) em 1952 e o segundo foi o Partido Comunista da Alemanha (Kommunistische Partei Deutschlands - KPD), pertencente à extrema direita. Todavia, nos últimos anos, a Corte mostrou-se mais tolerante frente a partidos considerados "antidemocráticos", de forma a comprovar a maior maturidade da democracia alemão no decorrer dos anos. BRUGGER, Winfried. The Treatment of Hate Speech in German Constitutional Law. Charlottesville: German Law Journal, Vol. 4, $\mathrm{n}^{\circ}$ 1, 2003. p. 5; Socialist Reich Party Case (1952), 2 BVerfGE I. Fragmentos deste caso estão em: KOMMERS, Donald P.; MILLER, Russel A. The Constitutional Jurisprudence of the Federal Republic of Germany. $2^{\mathrm{a}}$ ed.. Durham: Duke University Press, 1997. p. 218-224.
} 
sob a proteção de normas que garantem a paz pública e a ordem constitucional. ${ }^{157}$

No âmbito administrativo, apesar da proteção constitucional ao direito de reunião, sob $\mathrm{o}$ art. $8, \mathrm{BL}$, há a possibilidade de banir manifestações na hipótese de organização por partido político declarado inconstitucional pela Corte Federal, em razão do uso de discurso de ódio. Reuniões também possuem a probabilidade de serem proibidas ou dissolvidas, se autoridades públicas possuírem suspeita razoável de que haverá violações com base em ódio. O mesmo ocorre no caso de empresas que violam a proibição de incitação ao ódio, que podem ter seus negócios suspensos pela presença de hate speech e discriminação social.

Ademais, a regulação alemã de radiofusão próibe utilização de expressões raciais ou discurso de ódio que violem a dignidade do indivíduo e as leis de proteção à infância determinam a colocação de publicações que contenham escrito imorais, brutais, de glorificação da guerra ou incitação ao cometimento de atos violentos, capazes de ameaçar a construção moral de crianças e adolescentes, em lista restrita, com intuito de dificultar o acesso para esse público. ${ }^{158}$

O Código Civil alemão (Bürgerliches Gesetzbuch - BGB) é repleto de normas que barram os discursos odiosos, principalmente quando cominadas com as determinações penais. Dentre as principais disposições está a possibilidade, pelo artigo 823, (2) da BGB, de arbitramento de indenização no caso de utilização do hate speech para infligir dano a outrem. O ordenamento civilista também prevê a hipótese de pagamento de compensação pecuniária ou realização de retratação do ofensor em caso de divulgação de falsas afirmações de fatos (artigo 824 e 1004, BGB), além de

157 BRUGGER, Winfried. The Treatment of Hate Speech in German Constitutional Law. Charlottesville: German Law Journal, Vol. 4, nº 1, 2003. p. 14-19.

158 Ibid. 
dispor sobre a possibilidade de indenização pela criação de dor e sofrimento como consequência desses atos (artigo 847, BGB). ${ }^{159}$

Recentemente, após a passagem de ano de 2017 para 2018, legislação específica contra o discurso de ódio na Internet entrou em vigor na Alemanha, conhecida como Lei de Aplicação na Rede (Netzwerkdurchsetzungsgesetz - NetzDG). A nova medida obriga que plataformas de internet com mais de dois milhões de usuários tenham que implementar formas mais eficientes de denúncia e exclusão de conteúdos potencialmente ilegais, como notícias falsas e ameaças de violência e calúnia, que devem, após o recebimento de queixa, ser excluídos dentro de prazo de 24 horas para casos simples e sete dias em casos mais complexos. $\mathrm{Na}$ ocorrência de não cumprimento, as empresas podem ser multadas em até 50 milhões de euros. ${ }^{160}$

O Tribunal Constitucional Alemão é responsável pela análise de casos jurídicos apenas em relação a questões constitucionais, enquanto os tribunais ordinários possuem a função de julgar com base nas regulações infraconstitucionais. No âmbito das liberdades comunicativas, a Corte Constitucional pode vir a julgar um caso quando as instâncias inferiores ignoram a aplicabilidade de alguma liberdade constitucional ou não a interpretam de acordo com o correto alcance ou importância social. Nesse sentido, em razão do significado da liberdade de expressão para a autonomia individual, autogoverno, estabilidade política e ordem democrática, a Corte é chamada a agir nos casos de sua violação. Desta forma, o Tribunal Constitucional determina a possibilidade de proibição do hate speech a partir da análise das circunstâncias de cada caso concreto. ${ }^{161}$

No estudo da jurisprudência constitucional alemã, dentro das hipóteses de restrição da liberdade de expressão, Winfried Brugger separa

\footnotetext{
${ }^{159}$ Ibid.

160 Deutsche Welle. Lei contra discurso de ódio na internet entra em vigor na Alemanha. Disponível em: $<\mathrm{http}: / / \mathrm{m} . \mathrm{dw}$. com/pt-br/lei-contra-discurso-de-\%C3\%B3dio-na-internet-entra-emvigor-na-alemanha/a-41996447>. Acesso em 19 mar. 2018.

${ }^{161}$ BRUGGER, Winfried. The Treatment of Hate Speech in German Constitutional Law. Charlottesville: German Law Journal, Vol. 4, no 1, 2003. p. 21-23.
} 
os casos em três grandes grupos de violação: (i) insulto a indivíduos; (ii) insulto coletivo e discurso de ódio; (iii) Negação do Holocausto, simples e qualificada. ${ }^{162}$

No que tange ao insulto individual, o discurso de ódio é frequentemente dirigido contra uma coletividade identificada por suas características em comum, porém, tal discurso pode gerar consequências também para uma única pessoa. Nestes casos, quando há enquadramento do fato à tipificação do artigo 185 do Código Penal, relativa ao insulto ou difamação, há criminalização da conduta. Em Strauß Caricature Case (1987), ${ }^{163}$ Rainer Hachfeld publicou na revista Konkret diversas caricaturas do então governador do Estado da Baviera, Franz Josef Strauß, retratando-o como um porco envolvido em atividades sexuais. Em uma destas figuras, o governador aparece no corpo do animal enquanto copula com outro, em roupas judiciais. Em consequência, Strauß processou o caricaturista por difamação.

O tribunal local condenou o réu ao pagamento de multa monetária por difamação, porém, em grau de recurso, ocorreu a anulação do julgamento de primeira instância e absolvição. Apesar de sustentar que a crítica política deveria ser permissivamente ampla, a Corte Constitucional ponderou que sua forma legítima não inclui depreciação nem a utilização de características ultrajantes, não relacionadas à mensagem política. Como uma sátira, a caricatura de Strauß estaria coberta pela liberdade artística do art. 5 (3) da Constituição Alemã, visto que não contém cláusula de restrição. Contudo, por mais que caricaturas contenham elementos de exagero e distorção, no caso concreto, os direitos da dignidade da pessoa

\footnotetext{
162 BRUGGER, Winfried. Proibição ou proteção do discurso do ódio?: algumas observações sobre o direito alemão e o americano. Brasília: Instituto Brasiliense de Direito Público, ano 4, janeiro-março, 2007. p.124; BRUGGER, Winfried. The Treatment of Hate Speech in German Constitutional Law. Charlottesville: German Law Journal, Vol. 4, $n^{\circ}$ 1, 2003. p. 23.

${ }^{163}$ Strauß Caricature Case. [BVerfGE] 75, 369 (1987). Disponível em: $<$ https://law.utexas.edu/transnational/foreign-law-translations/german/case.php?id=634>. Acesso em 18 mar. 2018.
} 
humana e personalidade, art. 1 (1) e 2 (1) da BL, respectivamente, prevalecem sob a liberdade de expressão artística. ${ }^{164}$ Nas palavras da Corte:

[O que] obviamente se pretendida era um ataque à dignidade pessoal da pessoa caricaturada. Não foram suas feições humanas, suas particularidades pessoais que foram trazidas para a casa do observador através da compra escolhida. Ao contrário, a intenção era mostrar que ele tinha características "bestiais" marcantes e que ele se comportava de acordo com as mesmas. Particularmente, a representação de conduta sexual, a qual, no homem, ainda hoje, forma parte do âmago da vida íntima merecedora de proteção, tem por objetivo desvalorizar o indivíduo em questão como pessoa, privá-lo de sua dignidade como ser humano (...) um sistema jurídico que leva a dignidade do homem como o mais alto valor tem que desaprovar [tal conduta]. ${ }^{165}$

Quanto à classificação de insulto dirigido a um grupo e ao discurso de ódio, o direito alemão também criminaliza a difamação coletiva (artigos 185 e seguintes do Código Penal), desde que cumpridas condições definidas pelo Tribunal Constitucional no caso Tucholsky I: ${ }^{166}$ (i) o grupo atacado deve ser pequeno; (ii) as características da coletividade devem ser diferentes das do público em geral; (iii) a declaração de difamação deve atacar todos os membros do grupo, não apenas alguns indivíduos especificamente; (iv) a crítica difamatória deve fundar-se em elementos inalteráveis ou características atribuídas pela sociedade ao grupo, de forma a diferenciá-lo do resto, como atributos de etnia, raça, gênero ou religião. ${ }^{167}$

No referido caso, indivíduos foram processados por insulto, de acordo com o Código Penal, dirigido às Forças Armadas e seus membros. Um dos réus foi acusado de mostrar cobertor com as palavras, em inglês, "soldados são assassinos", escritas em vermelho, em uma estrada pela qual

164 BRUGGER, Winfried. The Treatment of Hate Speech in German Constitutional Law. Charlottesville: German Law Journal, Vol. 4, n 1, 2003. p. 25; Strauss Caricature Case. BVerfGE 75, 369 (1987). Disponível em: <https://law.utexas.edu/transnational/foreign-lawtranslations/german/case.php?id=634>. Acesso em 18 mar. 2018.

165 Ibid.

${ }^{166}$ Tucholsky Case. [BVerfGE] 93, 266. Disponível em: $<$ https://law.utexas.edu/transnational/foreign-law-translations/german/case.php?id=620>. Acesso em 18 mar. 2018.

167 BRUGGER, Winfried. Proibição ou proteção do discurso do ódio?: algumas observações sobre o direito alemão e o americano. Brasília: Instituto Brasiliense de Direito Público, ano 4, janeiro-março, 2007. p. 127. 
membros da OTAN passariam, ${ }^{168}$ enquanto a acusação de outro réu envolvia a distribuição de folhetos, escritos por ele, em uma exposição do Exército Federal, onde afirmava que soldados eram treinados para matar e, consequentemente, potenciais assassinos responsáveis por extermínio em massa, destruição, brutalidade, tortura, ameaças, terror e desumanidades. ${ }^{169}$ Membros ativos das forças armadas denunciaram todas as condutas à polícia, o que resultou na prisão, processo e sentenciamento dos responsáveis destes materiais por insulto coletivo, com base no art. 185 do Código Penal. ${ }^{170}$

A Corte Constitucional alemã anulou estes julgamentos, obrigandoos a retornarem às instâncias inferiores, por entender que as acusações não configuravam um ataque à dignidade humana, mas representavam uma crítica a uma questão de interesse público, abrangidas pelo direito de expressão. $\mathrm{O}$ interesse estatal pela liberdade de expressão e opinião em assuntos públicos exige que as críticas sejam limitadas apenas quando evidentemente difamatórias. ${ }^{171}$

Além do artigo 185 do Código Penal alemão, utilizado como base para condenação pelos tribunais de $1^{\mathrm{a}}$ instância nos casos mencionados, o artigo 130 do mesmo Código também pune os casos de difamação coletiva. Contudo, a aplicação desta ocorre apenas em ataques de ódio contra setores da população, especificamente grupos determinados por sua nacionalidade, raça, religião ou origem ética. Este dispositivo evita a proliferação de crimes de ódio que podem vir a ocorrer a partir da utilização da difamação coletiva. O sistema alemão, nesse sentido, pune o incitamento ao ódio e à violência contra grupos minoritários e estigmatizados muito antes que a conduta seja considerada como incitamento concreto para um ato criminoso

\footnotetext{
1681 BvR 1476/91.

${ }^{169} 1$ BvR 1980/91

170 BRUGGER, Winfried. Proibição ou proteção do discurso do ódio?: algumas observações sobre o direito alemão e o americano. Brasília: Instituto Brasiliense de Direito Público, ano 4, janeiro-março, 2007. p. 128.

${ }^{171}$ Tucholsky Case. [BVerfGE] 93, 266. Disponível em: $<$ https://law.utexas.edu/transnational/foreign-law-translations/german/case.php?id=620>. Acesso em 18 mar. 2018.
} 
determinado, uma vez que não há necessidade de existência de um risco iminente e presente. O incitamento ao ódio já é entendido pelo legislador germânico como uma elevação do risco de ruptura da paz pública, de forma a violar a dignidade e honra de minorias. ${ }^{172}$

O caso Titanic, ${ }^{173}$ julgado pela Corte Constitucional Alemã em 1998, engloba o hate speech quanto à sua caracterização como insulto individual e coletivo. A revista satírica Titanic descreveu um militar paraplégico, que havia sido reformado após um acidente, primeiramente, como "assassino nato" e, em edição posterior, como "aleijado", além de publicar ser inadmissível que o militar estivesse determinado a retornar ao exército alemão, cujo objetivo é o de aleijar e matar pessoas. ${ }^{174}$ Os tribunais infraconstitucionais condenam a revista ao pagamento de indenização por danos morais. Contudo, a Corte Constitucional considerou que a sátira ao desejo do militar de retornar ao exército fazia parte de uma crítica pacifista contra o militarismo, e, por isso, invalidou a condenação quanto a alegação de "assassino nato". Todavia, o Tribunal manteve a condenação pela utilização da palavra "aleijado" por considerar o propósito único de humilhar e depreciar o militar.

As normas alemãs de insulto coletivo e incitamento ao ódio assumem posição ainda mais relevante nos casos que envolvem o Holocausto. Para Winfried Brugger, as mentiras ou negações de ocorrência do Holocausto podem ser classificadas como simples ou qualificada. A primeira abrange os casos em que os defensores da mentira insistem que não houve genocídio de judeus durante o período da Alemanha Nazista ou

\footnotetext{
${ }^{172}$ BRUGGER, Winfried. Proibição ou proteção do discurso do ódio?: algumas observações sobre o direito alemão e o americano. Brasília: Instituto Brasiliense de Direito Público, ano 4, janeiro-março, 2007. p. 128.

${ }_{173}$ [BVerfGE] 86, 1.

174 ALEXY, Robert. Balancing, Constitutional Review and Representation. International Journal of Constitutional Law, Vol. 3, Issue 4, 2005. p. 572-581. Disponível em: $<$ https://ssrn.com/abstract=914967>. Acesso em 18 mar. 2018; SARMENTO, Daniel. A Liberdade de Expressão e o Problema do Hate Speech. Rio de Janeiro, 2006. Disponível em $<$ http://www.dsarmento.adv.br/content/3-publicacoes/18-a-liberdade-de-expressao-e-o-problemado-hate-speech/a-liberdade-de-expressao-e-o-problema-do-hate-speech-daniel-sarmento.pdf $>$. Acesso em 18 mar. 2018.
} 
que, se ocorreu, não foi na escala relatada. Seguindo esta visão, a simples negação do Holocausto se torna qualificada quando acompanhada por conclusões normativas adicionais ou chamamentos à ação. Ambas as declarações falsas a respeito do genocídio de judeus são atualmente puníveis pelo ordenamento alemão, através dos artigos 130 e 185 do Código Penal. ${ }^{175}$

Em Auschwitz lie,${ }^{176}$ uma associação convidou o historiador David Irving, conhecido como revisionista de extrema direita, para atuar como palestrante em um evento. O governo da Baviera, então, condicionou a realização do evento ao cumprimento de certas obrigações estabelecidas pela lei local, dentre elas, a não abordagem de questões relacionadas à negação do Holocausto. A autoridade local viu-se obrigada a tomar tais atitudes por acreditar haver razões suficientes para presumir a ocorrência de crimes de ódio, como dispõe os artigos 130, 185, 189 e 194 do Código Penal alemão.

A Corte Constitucional alemã sustentou que o direito à liberdade de expressão protege e garante opiniões, isto é, declarações que contenham relação subjetiva entre o indivíduo e o conteúdo da ideia. Por isso, opiniões não poderiam ser consideradas falsas ou verdadeiras, recebendo proteção constitucional independentemente de serem fundamentadas ou não, emocionais ou racionais, valiosas ou inúteis, perigosas ou inofensivas. Declarações de um fato, porém, não são o mesmo que opiniões e, por essa razão, são suscetíveis de análise da veracidade de seu conteúdo, sem deixar de serem protegidas pela liberdade de expressão, na medida em que são prérequisitos para a formação de uma cultura de opiniões plurais. Todavia, a proteção das afirmações de fato acaba no ponto em que deixam de contribuir para a formação de opiniões. Por esse motivo, o Tribunal

175 BRUGGER, Winfried. Proibição ou proteção do discurso do ódio?: algumas observações sobre o direito alemão e o americano. Brasília: Instituto Brasiliense de Direito Público, ano 4, janeiro-março, 2007. p. 130-131.

${ }_{176}$ Auschwitz lie. [BVerfGE] 90, 241-255. Disponível em: $<$ https://law.utexas.edu/transnational/foreign-law-translations/german/case.php?id=621>. Acesso em 18 mar. 2018. 
Constitucional Federal declarou que a afirmação de fato, conhecida ou comprovada como falsa, não é coberta pela garantia da liberdade de opinião. ${ }^{177}$

Dentro do julgamento em questão, a Corte declarou a negação do Holocausto e perseguição dos judeus durante o Terceiro Reich como uma afirmação de fato, cujo conteúdo já se comprovou falso por inúmeras testemunhas, documentos e pesquisas, não recebendo proteção constitucional da liberdade de expressão. Além disso, o Tribunal Constitucional entende que a simples negação de ocorrência do genocídio judeu já implicaria a continuidade das atrocidades cometidas durante o período nazista. De acordo com o Tribunal:

O fato histórico de que seres humanos foram separados de acordo com critérios estabelecidos nas "Leis de Nuremberg" e roubados de sua individualidade com o objetivo de seu extermínio dá aos judeus que vivem na República Federal [da Alemanha] uma relação pessoal especial com seus cidadãos; nessa relação, o passado ainda está presente hoje. Faz parte de sua própria percepção pessoal e de sua dignidade de que eles sejam vistos como pertencentes a um grupo de pessoas que se destaca em razão de seu curso de vida, em relação ao qual todos os outros possuem uma responsabilidade moral especial. O respeito por essa percepção pessoal é para cada uma delas uma das garantias contra a repetição da discriminação e uma condição básica para sua vida na República Federal. Quem procurar negar esses eventos nega a cada um individualmente esse valor pessoal ao qual eles têm uma reivindicação. Para os afetados, isso significa a continuação da discriminação contra o grupo de seres humanos a que eles pertencem. ${ }^{178}$

O caso mais recente envolvendo a condenação pelo discurso de ódio a partir da negação do Holocausto ocorreu em outubro de 2017. A Alemã Ursula Haverbeck, 89 anos, foi condenada por refutar a ocorrência do extermínio de milhões de judeus na Alemanha nazista. A idosa foi apelidada pela mídia de "vovó nazista", pois já foi condenada diversas vezes pela prática do mesmo crime. Em outras ocasiões, Haverbeck alegou que o campo de concentração de Auschwitz nunca foi utilizado para 
extermínio em massa e que o Holocausto é a maior mentira da história. ${ }^{179}$ Após diversas condenações, recentemente a idosa foi detida por autoridades locais para cumprimento da pena de dois anos de prisão. ${ }^{180}$

Por meio desta análise jurisprudencial e doutrinária, nota-se que o entendimento alemão não enquadra o hate speech como conteúdo protegido pela liberdade de expressão, sem descuidar deste direito fundamental essencial, principalmente em casos que envolvam questões de interesse público. Em um país sobrevivente e traumatizado pelo regime nazista, a dignidade humana e a igualdade são pilares indispensáveis que levam o sistema alemão a proibir os discursos de ódio o mais cedo possível, através de regulamentações e restrições, mesmo quando não envolve perigo iminente de ocorrência de atos de ódio.

\subsubsection{O Sistema Europeu de Direitos Humanos}

O Sistema Europeu de Proteção aos Direitos Humanos originou-se a partir da criação do Conselho da Europa, em 1949, responsável pela edição da Convenção Europeia de Proteção aos Direitos Humanos e Fundamentais. Esta, além de conter disposições sobre dez direitos fundamentais, estabeleceu a criação dos dois principais órgãos do sistema: a Comissão Europeia de Direitos Humanos (Comissão EDH) e a Corte Europeia de Direitos Humanos (órgão jurisdicional - CEDH). ${ }^{181}$

$\mathrm{O}$ art. 10 da Convenção Europeia dispõe sobre a liberdade de expressão, que compreende a opinião, recebimento e transmissão de informações e ideias sem a ingerência de quaisquer autoridades públicas. Já o parágrafo $2^{\circ}$ do mesmo artigo autoriza restrições a esse direito, desde que

\footnotetext{
179 Deutsche Welle. Alemã de 88 anos é condenada por negar Holocausto. Disponível em: $<$ http://www.dw.com/pt-br/alem\%C3\%A3-de-88-anos-\%C3\%A9-condenada-por-negarholocausto/a-40974633>. Acesso em 19 mar. 2018.

${ }^{180}$ Deutsche Welle. Alemã de 89 anos começa a cumprir pena por negar Holocausto. Disponível em: $\quad<$ http://www.dw.com/pt-br/alem\%C3\%A3-de-89-anos-come\%C3\%A7a-a-cumprir-pena-pornegar-holocausto/a-43692520>. Acesso em 21 mai 2018.

${ }^{181}$ HART, James W. The European Human Rights System. Cincinnati: Law Library of University of Cincinnati College of Law Scholarship and Publications, Paper 533, 2010. p. 533-559.
} 
previstas previamente pela lei e que sejam necessárias, em uma sociedade democrática, para a segurança pública e nacional, integridade territorial, defesa da ordem, prevenção de crimes e proteção da honra e outros direitos fundamentais. Interessante também analisar o conteúdo do art. 17, pois trata da possibilidade de restrição de liberdades que ameacem valores e direitos essenciais estabelecidos pela Convenção.

Em 1997, o Comitê de Ministros do Conselho da Europa divulgou sua Recomendação (97) 20, ${ }^{182}$ cujo tema central era o hate speech. O segundo princípio do documento obriga os governos dos Estados a estabelecer e manter um cenário legal sólido, constituído de disposições civis, penais e administrativas, sobre o discurso de ódio, de forma a permitir que as autoridades administrativas e judiciais possam, caso a caso, conciliar o respeito à liberdade de expressão com a garantia da dignidade humana e proteção da reputação e Direito dos indivíduos. Eventuais restrições a esta liberdade, pelo princípio $\mathrm{n}^{\circ} 3$, devem ser restritas e aplicáveis de forma lícita e não arbitrária, baseadas em critérios objetivos e suscetível de controle judicial. Ademais, o princípio $\mathrm{n}^{\mathrm{o}} 6$ faz uma distinção entre a responsabilidade dos meios de comunicação e a do autor da expressão odiosa, enquanto o princípio $\mathrm{n}^{\circ} 7$ reforça a obrigação de os Estados cumprirem as determinações do art. 10 da Convenção Europeia de Direitos Humanos.

Ao contrário do Sistema Interamericano de Direitos Humanos, o Sistema Europeu possui jurisprudência relativa ao discurso de ódio, através de decisões jurisprudenciais da Corte Europeia de Direitos Humanos. Em Vogt Vs. Germany, ${ }^{183}$ em 1992, a alemã Dorothea Vogt era professora permanente de escola estadual em Jever, quando, em 1968, por meio de sanção disciplinar, foi suspensa de seus serviços em razão de sua filiação ao Partido Comunista Alemão (DKP). Posteriormente, a Corte Administrativa

\footnotetext{
${ }^{182}$ Comitê de Ministros do Conselho da Europa. Recomendação (97) 20. Disponível em $<\mathrm{https}: / / \mathrm{rm}$.coe.int/1680505d5b >. Acesso em 19 mar. 2018.

${ }^{183}$ Vogt Vs. Germany. ECHR (Plenary), $\mathrm{n}^{\circ}$ 17851/91.1992. Disponível em $<\mathrm{http} / / /$ freecases.eu/Doc/CourtAct/4540252>. Acesso em 19 mar. 2018.
} 
entendeu que a professora havia violado seu dever de lealdade política, sancionando-a com a demissão. Após superar todas as instâncias internas, a $\mathrm{CEDH}$ determinou que os Tribunais Alemães violaram a liberdade de expressão e associação sob os artigos 10 e 11, respectivamente, da Convenção Europeia de Direitos Humanos ao estabelecerem uma perseguição aos inimigos comunistas.

Em Jersild Vs. Denmark (1994), ${ }^{184}$ a Corte Europeia reverteu a condenação criminal do jornalista Jens Olaf Jersild por facilitar e produzir entrevista de três membros do grupo Greenjackets, conhecidos por suas declarações depreciativas sobre minorias raciais e imigrantes na Dinamarca e em todo mundo. A CEDH considerou que o Estado dinamarquês violou a liberdade de expressão de Jersild, pois integrante da mídia, responsável pela transmissão de questões de interesse público, como o ódio racial. Apesar de as mensagens divulgadas pelo grupo serem altamente ofensivas, o jornalista não poderia ser punido pela divulgação de ideias de terceiros.

No mesmo sentido, em 1998, no caso Lehideux and Isorni Vs. France, ${ }^{185}$ a CEDH invalidou condenação proferida pelas Cortes Francesas de cidadãos que publicaram documento onde defendiam atos de Marechal Pétain, chefe de Estado durante a República de Vichy, considerado colaborador do regime nazista. A Corte Europeia entendeu que a referida condenação era prevista na legislação francesa, porém desnecessária em uma sociedade democrática e, por isso, violava o art. 10 da Convenção Europeia de Direitos Humanos, uma vez que a defesa e humanização do general não se equiparavam aos casos de negação do Holocausto, não protegidos pela liberdade de expressão.

\footnotetext{
${ }^{184}$ Jersild $\quad V S$. Denmark. ECHR, $\quad \mathrm{n}^{\mathrm{o}}$ 15890/89.1994. Disponível em $<$ https://globalfreedomofexpression.columbia.edu/cases/jersild-v-denmark/>. Acesso em 19 mar. 2018.

${ }^{185}$ Lehideux and Isorni Vs. France. ECHR, no 24662/94.1998. Disponível em <https://www.legaltools.org/doc/2fed5c/pdf/>. Acesso em 19 mar. 2018.
} 
Em Otto-Preminger Institut VS. Austria, ${ }^{186}$ no ano de 1995, a Corte Europeia confirmou a apreensão e banimento do filme religioso satírico Das Liebeskonzil (Conselho dos Céus), cujo teor retratava Deus como um velho senil e impotente, e Maria, mãe de Deus, como uma mulher promíscua. A decisão considerou que a apreensão realizada pelo governo austríaco possuía objetivo legítimo de proteção das crenças religiosas insultadas pela publicação do filme e, consequentemente, não era violação à liberdade de expressão.

Um dos casos mais recentes julgados pela Corte Europeia de Direitos Humanos foi Garaudy vs. France, em 2003. ${ }^{187}$ O julgamento envolveu a publicação de livro revisionista, cujo conteúdo continha negações de crimes contra a humanidade (Holocausto). A Corte Europeia, em concordância com os tribunais nacionais, considerou que a referida negação é uma das mais severas formas de discriminação racial e incitação ao ódio aos judeus, uma vez que a simples negação ou releitura do acontecimento elimina os valores fundamentais que baseiam a luta contra o antissemitismo e racismo. Desta forma, a publicação do livro foi julgada desprotegida pela liberdade de expressão, de acordo com o art. 17 da Convenção, por ser incompatível com a democracia e direitos humanos.

A partir deste cenário, nota-se que a Corte Europeia de Direitos Humanos analisa a restrição de direitos fundamentas segundo alguns critérios: legalidade da medida restritiva, objetivo legítimo para fundamentar esta restrição e a necessidade para preservação de uma sociedade democrática. ${ }^{188}$ Desta forma, o Sistema Europeu de Direitos Humanos aproxima-se da realidade germânica, ao permitir restrições à liberdade de expressão e, dentre elas, o hate speech, mesmo quando não há clara iminência de incitação ao ódio.

\footnotetext{
${ }^{186}$ Otto-Preminger Institut Vs. Austria. ECHR, $\mathrm{n}^{\circ}$ 13470/87. Disponível em $<\mathrm{https}$ ://globalfreedomofexpression.columbia.edu/cases/otto-preminger-institut-v-austria $>$. Acesso em 20 mar. 2018.

${ }^{187}$ Garaudy vs. France. CEDH, $\mathrm{n}^{\circ}$ 65831/01. 2003.

${ }^{188}$ DELMAS-MARTY, Mireille. Por um direito comum. São Paulo: Martins Fontes, 2004. p. 153.
} 


\subsection{Standards Internacionais}

Após análise do cenário doutrinário e jurisprudencial dos países e sistemas mencionados, essencial a abordagem complementar dos standards internacionais, desenvolvidos por Organismos Internacionais, para o entendimento de possíveis soluções para a problemática do discurso de ódio ao redor do mundo.

A ONG Artigo 19, ${ }^{189}$ cujo objetivo é a proteção da liberdade de expressão e informação no cenário internacional, elaborou os Camden Principles, que representam uma interpretação progressiva do direito internacional e standards, preparados conjuntamente com as Nações Unidas, sociedade civil e acadêmicos especialistas no tema, de forma a promover um maior consenso internacional a respeito da relação entre liberdade de expressão e promoção da igualdade - os princípios foram desenvolvidos através do entendimento de que ambos são direitos fundamentais essenciais que atuam de forma complementar para a salvaguarda da dignidade humana. ${ }^{190}$

O documento elaborado parte do princípio de que algumas formas de discurso, como o incitamento ao ódio racial, são tão danosas para o direito à igualdade que devem ser proibidos. No entanto, esta limitação precisar ser restritivamente definida por lei, com o intuito de evitar a ocorrência de usurpação e abuso, e sua aplicação deve ser realizada de forma equânime para o benefício de todos os grupos protegidos. Com esta finalidade, análise caso a caso mostra-se relevante, para que haja avaliação das circunstancias específicas de vulnerabilidade das vítimas e contexto, principalmente por parte das autoridades judiciais, a fim de evitar que as restrições sejam utilizadas a partir de crenças pessoais, ideologias e religião para benefício próprio.

\footnotetext{
${ }^{189}$ Site official da ONG Article 19: https://www.article19.org/.

190 Article 19. The Camden Principles on Freedom of Expression and Equality. Disponível em $<$ https://www.article19.org/data/files/pdfs/standards/the-camden-principles-on-freedom-ofexpression-and-equality.pdf $>$. Acesso em 21 mar. 2018.
} 
A primeira parte dos Camden Principles reafirma a obrigação dos Estados-membros com a ratificação e incorporação de documentos de Direitos Humanos que estabeleçam a liberdade de expressão e igualdade, garantindo-os em seus ordenamentos internos. $\mathrm{O}$ documento recomenda que sejam postos à disposição das vítimas remédios judiciais e não judiciais para salvaguarda de seus direitos, assim como sugere a regulação da mídia, através de órgãos independentes do governo, para a promoção do acesso e debate amplo das mais variadas ideias. Aconselha também a negação do uso de expressões discriminatórias das minorias, principalmente por parte da mídia, com o intuito de que todos os grupos, inclusive aqueles em desvantagem, tenham acesso igualitário aos conteúdos. Além disso, indica a existência de direitos de correção e resposta para a promoção da livre circulação de informações, sem que isso importe na exclusão de outras garantias e remédios legais. Propõe também o ensino de matérias relacionadas aos direitos humanos, com o intuito de estimular o debate e entendimento intercultural, para que se evitem declarações que promovam discriminação ou enfraqueçam a igualdade, com o objetivo de garantir o combate à formação de estereótipos negativos. Ademais, a mídia, figuras públicas, políticos e organizações da sociedade civil devem possuir papel na luta contra a discriminação e o uso de estereótipos, evitando referências desnecessárias a características como raça, religião, gênero e demais grupos de qualificações que possam promover a intolerância e minar a igualdade.

Em seu último tópico, os Camden Principles abordam especificamente a problemática do discurso de ódio. O princípio 11 determina a regra geral de que a liberdade de expressão não deve ser limitada e estabelece uma série de requisitos para a legalidade de uma restrição imposta a esse direito. Limitações devem ser estritamente definidas por lei, de forma a atingir apenas os discursos odiosos, para um objetivo legítimo - proteção de direitos e da reputação; segurança nacional; ordem pública; saúde e moral pública; proteção dos fins democráticos. Ademais, elas precisam ser a última ratio a ser utilizada, apenas quando não 
há outro meio menos danoso de solução, de maneira proporcional, isto é, o benefício para o interesse ou direito protegido deve sobressair ao dano à liberdade de expressão.

O princípio 12 recomenda a adoção de legislações de proibição ao ódio nacional, racial e religioso que constituam incitação à discriminação, hostilidade e violência (discurso de ódio). As leis nacionais restritivas devem adotar alguns conceitos, tais como: (i) os termos "ódio" e "hostilidade" referem-se ao desprezo intenso e emoções irracionais sentidas contra o grupo alvo; (ii) a expressão "defesa" deve ser entendida como a intenção de promover a divulgação do ódio por uma certa coletividade; (iii) "incitação" refere-se ao discurso proferido contra determinado grupo, definido por sua nacionalidade, raça ou religião, cujo conteúdo cria iminente risco de discriminação, hostilidade ou violência; (iv) a promoção de um senso positivo de identidade coletiva não qualifica-se como discurso de ódio. O princípio também indica que os Estados devem proibir teorias revisionistas, cujo objetivo é negar a ocorrência de crimes contra a humanidade, mas não devem restringir críticas direcionadas às ideias particulares, crenças ou ideologias, senão quando classificadas como hate speech. Por fim, o documento propõe a existência de remédios legais eficientes para utilização das vítimas, recomendando que os Estados façam revisão legal da estrutura de suas leis restritivas da liberdade de expressão, para que se adequem aos pressupostos estabelecidos.

O Rabat Plan of Action é um relatório preparado em 2012, pelo Alto Comissário das Nações Unidas em Direitos Humanos, organizado através de diversos workshops a respeito da proibição da defesa do incitamento ao ódio nacional, racial e religioso que constitui chamamento para a discriminação, hostilidade e violência. $\mathrm{O}$ objetivo central do documento é estabelecer variadas recomendações para conciliar o direito à liberdade de expressão com as eventuais proibições de discursos de ódio. Os pesquisadores levantaram a existência de três problemas relevantes: legislações contrárias ao hate speech são qualificadas como excessivamente 
abrangentes ou vagas; jurisprudência do assunto é escassa ou ad hoc; e políticas são, majoritariamente, descumpridas pela falta de foco ou dispositivos impactantes. As recomendações, por conseguinte, variam de acordo com estas três temáticas: legislativas, judiciais e políticas. ${ }^{191}$

$\mathrm{Na}$ esfera legislativa, o documento revela que a maioria dos países não possui legislação que proíba o discurso de ódio e, quando possui, é vaga ou inconsistente com as definições internacionais do hate speech, ${ }^{192} \mathrm{o}$ que permite a aplicação de forma arbitrária, além da existência de restrições distintas e variadas em cada lugar do mundo, variando também as formas de sanção entre medidas civis, criminais ou administrativas.

A primeira recomendação nesta área é o estabelecimento de diferenciação efetiva entre expressões que constituam crimes; aquelas que não são criminalmente punidas, mas justificam sanções civis ou administrativas; e, por fim, discursos que não são suscetíveis de punição e promovem preocupação no que refere à tolerância. Por isso, o relatório entende ser fundamental a definição estrita e correta de todos os termos, com auxílio dos Camden Principles, especialmente no que tange às expressões "ódio", “incitação", "violência” e "hostilidade”. Além disso, recomendam que os Estados se utilizem dos princípios da legalidade, proporcionalidade e necessidade para aplicação das restrições à liberdade de expressão, principalmente em relação às sanções aplicáveis, e a adoção e implemento de leis internacionais e nacionais, repressivas e preventivas, para o combate ao incitamento ao ódio.

No âmbito das recomendações jurisprudenciais, o relatório observa que a maioria das vítimas de discurso de ódio pertencem a grupos

\footnotetext{
${ }^{191}$ Office of the High Commissioner for Human Rights (OHCR). Rabat Plan of Action on the prohibition of advocacy of national, racial or religious hatred that constitutes incitement to discrimination, hostility or violence. Morocco, 2012. Disponível em: $<$ http://www.ohchr.org/Documents/Issues/Opinion/SeminarRabat/Rabat_draft_outcome.pdf $>$. Acesso em 21 mar. 2018.

192 O Rabat Plan of Action estabelece que as definições de discurso de ódio que devem ser assumidas pelos Estados soberanos estão definidas nos artigos 18, 19 e 20 do Pacto Internacional dos Direitos Civis e Políticos e art. $4^{\circ}$ da Convenção Internacional sobre a Eliminação de Todas as Formas de Discriminação Racial (vide nota de rodapé $\mathrm{n}^{\circ} 102$ ).
} 
minoritários que, muitas vezes, não possuem adequado acesso ao Judiciário, o que é agravado pela ausência de legislações específicas sobre o tema. O documento ressalta que, em razão da essencialidade da liberdade de expressão, as restrições aos discursos devem ser efetuadas apenas quando a incitação ao ódio é realizada de maneira grave e profunda. Nesse sentido, seis elementos devem ser levados em consideração para esta análise: (i) contexto social e político da época do discurso; (ii) posição e status do autor da fala na sociedade e para quem ele se dirige; (iii) intenção do agente, isto é, de acordo com o art. 20 do Pacto Internacional dos Direitos Civis e Políticos, a mera negligência ou imperícia não são suficientes para qualificar um ato como uma "ofensa", mas a intenção de incitar ou defender a violência e o ódio; (iv) conteúdo e forma, onde a análise deve levar em consideração o grau de discurso provocativo e direto, além da forma, estilo e natureza dos argumentos; (v) extensão do discurso, o que abrange o alcance do mesmo, além do tamanho do público e o local de realização (público ou privado); (vi) probabilidade e iminência do discurso atingir a sua finalidade de incitar ações concretas contra um grupo alvo específico.

Desta forma, a recomendação jurisdicional abrange a necessidade de aplicação dos standards internacionais em âmbito interno, de forma a garantir o direito a um julgamento justo por autoridade imparcial, independente e competente, definida pela lei. O Estado deve garantir amplo acesso aos remédios judiciais, principalmente para minorias historicamente excluídas e grupos vulneráveis, cuja assistência é necessária. E, por fim, as sanções criminais, relacionadas ao uso do hate speech, devem ser vistas como a última solução, aplicáveis apenas em situações restritas e severas, priorizando a utilização de sanções civis (indenização pecuniária, direito de correção e resposta, entre outros) e administrativas, preferencialmente.

Em relação às recomendações políticas, o estudo realizado demonstra que, além de medidas judiciais e legislativas, há necessidade de iniciativa de diversos setores da sociedade para fomentar a consciência social, tolerância e debate público, criando e fortalecendo uma cultura de 
paz, tolerância e respeito mútuo entre todos. Essencial também o desenvolvimento de uma educação voltada para os Direitos Humanos, a inclusão de minorias e eliminação de todas as formas discriminatórias e estereotipadas, possibilitando o exercício da liberdade de expressão também por grupos marginalizados. Recomenda-se a ampliação das relações de cooperação entre Estados e mecanismos internacionais de proteção aos Direitos Humanos e a atuação de grupos não governamentais e da sociedade civil na promoção de mecanismos que promovam maior diálogo intercultural. 


\section{CAPÍTULO 3 - O EMBATE ENTRE LIBERDADE DE EXPRESSÃO E DISCURSO DE ÓDIO NO BRASIL}

Com a redemocratização do Estado brasileiro, a Constituição Federal de 1988 dispõe sobre a liberdade de expressão (art. $5^{\circ}$, IV e IX), igualdade (art. $5^{\circ}$, caput), dignidade da pessoa humana (art. $1^{\circ}$, III) e proibição da prática do racismo (art. $4^{\circ}$, VIII e art. $5^{\circ}$, XLII), além da proteção de diversos direitos e garantias assegurados através da ratificação de convenções e tratados internacionais de direitos humanos. ${ }^{193} \mathrm{O}$ direito de exprimir ideias ganhou força com a expressa vedação à censura (art. $5^{\circ}$, IX e art. $220, \S 2$ ), porém, atualmente, a realidade não é mais de um governo ditatorial, que busca calar previamente opositores, ${ }^{194}$ mas de juízes e legisladores que procuram fórmulas para o equilíbrio entre princípios constitucionais colidentes. ${ }^{195}$ Dentre eles, há o aparente embate entre liberdade de expressão, igualdade e dignidade da pessoa, através do debate sobre a proibição do discurso de ódio.

Esta questão torna-se extremamente problemática com a inexistência de legislação interna específica a respeito do hate speech, frequentemente referido como um sinônimo de "racismo". A lei 7.716/89, art. 20, estabelece como crime a prática, indução ou incitamento de discriminação ou preconceito de raça, cor, etnia, religião ou procedência nacional, com pena de reclusão de um a três anos e multa. Apesar da menção à "discriminação", e da não conceituação do termo "discurso de ódio", a

\footnotetext{
${ }^{193}$ Dentre os documentos internacionais ratificados, há o Pacto Internacional sobre os Direitos Civis e Políticos (Decreto n ${ }^{\circ}$ 592/1992), Convenção Interamericana de Direitos Humanos (Decreto n ${ }^{0}$ 678/1992), Pacto Internacional para Eliminação de Todas as Formas de Discriminação Racial (Decreto $\mathrm{n}^{\circ}$ 65.810/1969), entre outros.

${ }_{194}$ Atualmente, enfrentamos problemas distintos, como a divulgação de fake news e a maior propagação do ódio por meio da internet, porém, a princípio, a expressão da oposição política não é reprimida, como observamos na grande variedade de partidos políticos e a polarização política no Brasil.

${ }^{195}$ SARMENTO, Daniel. A Liberdade de Expressão e o Problema do Hate Speech. Rio de Janeiro, 2006. Disponível em http://www.dsarmento.adv.br/content/3-publicacoes/18-a-liberdade-deexpressao-e-o-problema-do-hate-speech/a-liberdade-de-expressao-e-o-problema-do-hate-speechdaniel-sarmento.pdf
} 
tendência é a utilização do referido artigo em casos envolvendo este assunto, como veremos a seguir. ${ }^{196}$

\subsection{Casos Jurisprudenciais}

O leading case a respeito desta problemática no Brasil foi julgado pelo STF em 2003, conhecido como "Caso Ellwanger" (Habeas Corpus 82.424-2/RS). ${ }^{197}$ Siegfried Ellwanger foi responsável por editar, distribuir e vender livros de conteúdo antissemita, racista e discriminatório de sua autoria e da autoria de outros autores, nacionais e estrangeiros, onde defendia ideias de negação à ocorrência do Holocausto e atribuía aos judeus características degradantes, o que o levou a ser denunciado pelo crime de racismo em 1991 por violação do art. 20 da Lei 7.716/89, com redação da Lei 8.081/90. Apesar de absolvido pela $8^{\mathrm{a}}$ Vara Criminal de Porto Alegre, o Tribunal de Justiça do Rio Grande do Sul reverteu a decisão para condenálo a dois anos de reclusão e o Superior Tribunal de Justiça (STJ) negou provimento ao Habeas Corpus (HC) impetrado pelos advogados do réu. Por fim, o caso chegou ao Supremo Tribunal Federal (STF) que, pela maioria de oito votos a três, confirmou a negativa do pedido de Habeas Corpus.

O ponto central da defesa de Ellwanger baseava-se na premissa de que o povo judeu não poderia ser qualificado como raça $\mathrm{e}$, consequentemente, o paciente não teria incorrido no crime de racismo, imprescritível pela Constituição de 1988 (art. 5º, XLII), mas em mero ato de discriminação e preconceito, não abarcados pela imprescritibilidade constitucional, o que levaria à extinção da punibilidade pela prescrição da pretensão punitiva. Para solucionar a controvérsia, o STF precisou analisar a extensão do conceito "racismo", através da indagação se o povo judeu

\footnotetext{
${ }^{196}$ SILVA, Priscilla Regina da. Os Limites Sagrados da Liberdade: uma análise do discurso de ódio contrarreligioso. Rio de Janeiro. Março de 2017. Dissertação em Pós-Graduação em Direito PUC-Rio. p. 152.

${ }^{197}$ STF, HC no 82.424-2/RS, Rel. Ministro Moreira Alves, Brasília, 17 set. 2003. Disponível em $<\mathrm{http}: / /$ redir.stf.jus.br/paginadorpub/paginador.jsp?docTP $=\mathrm{AC} \&$ docID=79052>. Acesso em 27 mar. 2018.
} 
estaria, ou não, enquadrado no entendimento de raça. Os votos dos ministros do Supremo Tribunal fundamentaram-se em argumentos diversos - muitos deles não importantes para o âmbito desta monografia - e, por esta razão, abordarei apenas os que considerei mais relevantes.

O ministro relator, Moreira Alves, defendeu o provimento do pedido de $\mathrm{HC}$, decidindo pela extinção da punibilidade pela ocorrência de prescrição, por considerar que o termo "racismo" deveria ser interpretado restritivamente. Primeiramente porque o art. $5^{\circ}$, XLII não aborda toda e qualquer forma de preconceito ou de discriminação, não estando abrangidas as ideias preconceituosas ou discriminatórias em razão da idade ou sexo, por exemplo, e porque a imprescritibilidade prevista no referido artigo não alcança sequer os crimes considerados hediondos, como a prática de tortura, tráfico ilícito de entorpecentes e o terrorismo. ${ }^{198}$ Com auxílio a uma interpretação histórica da Constituição, o ministro ressaltou que a intenção original do constituinte foi a de proteção apenas contra a discriminação da raça negra, não estando os judeus englobados nesta norma constitucional, por não serem considerados uma raça, inclusive por autores judeus.

Em oposição, o Ministro Maurício Corrêa, apesar de reconhecer não haver dúvidas a respeito do fato de os judeus não constituírem uma raça, a partir da visão tradicional, e que a vontade do constituinte originário era de que a imprescritibilidade dos crimes de racismo fosse apenas para defesa da comunidade negra, defendeu, a partir de pesquisar científicas, não existir mais a classificação biológica de raça, por tratar-se de apenas uma: a raça humana. Desta forma, a construção da ideia de raça, pelo ministro, foi através de uma análise político-social originada da intolerância. Senão vejamos:

(...) o racismo traduz valoração negativa de certo grupo humano, tendo como substrato características socialmente semelhantes, de modo a configurar uma raça

\footnotetext{
${ }^{198}$ Para o ministro, a expressão "nos termos da lei”, presente na parte final do art. 5, XLII, CF, não delega ao legislador ordinário a função de dar o entendimento que lhe aprouver sobre o significado de racismo, mas apenas cabe a ele tipificar as condutas em que consiste esta prática, além de quantificar a pena.
} 
distinta, à qual se deve dispensar tratamento desigual da dominante. Materializase à medida que as qualidades humanas são determinadas pela raça ou grupo étnico a que pertencem, a justificar a supremacia de uns sobre os outros (...) Embora hoje não se reconheça mais, sob o prisma científico, qualquer subdivisão da raça humana, o racismo persiste enquanto fenômeno social, o que quer dizer que a existências das diversas raças decorre de mera concepção história, política e social, e é ela que deve ser considerada na aplicação do direito. É essa circunstância de natureza estrita e eminentemente social e não biológica que inspira a imprescritibilidade do delito previsto no inciso XLII do artigo $5^{\circ}$ da Carta Política. ${ }^{199}$

Desta forma, Maurício Corrêa votou pelo indeferimento do HC, ao considerar o racismo como um comportamento reprovável que decorre da convicção de que há hierarquia entre os grupos humanos, suficiente para justificar atos de segregação, inferiorização e até eliminação de pessoas, o que permitiria a restrição da liberdade de expressão.

No mesmo sentido foi o voto do Ministro Gilmar Mendes, porém com fundamentação diversa, por meio da utilização do princípio da proporcionalidade. ${ }^{200}$ Recorrendo a alguns clichês, ${ }^{201}$ o ministro defendeu que a liberdade de expressão "não é absoluta" e, por isso, deve ser compatibilizada com os demais direitos fundamentais. Para Gilmar Mendes, a condenação do paciente seria adequada para se alcançar o fim almejado (a salvaguarda de uma sociedade plural e tolerante); necessária, devido à inexistência de outro meio menos gravoso e igualmente eficaz para o mesmo resultado; e proporcional em sentido estrito, de forma a garantir a devida proporção entre a preservação dos valores de uma sociedade

${ }^{199}$ STF, HC no 82.424-2/RS, Rel. Ministro Moreira Alves, Brasília, 17 set. 2003. Disponível em $<$ http://redir.stf.jus.br/paginadorpub/paginador.jsp?docTP=AC\&docID=79052>. Acesso em 27 mar. 2018.

${ }^{200}$ De acordo com Gilmar Mendes: “(...) a aplicação do princípio da proporcionalidade se dá quando verificada restrição a determinado direito fundamental ou um conflito entre distintos princípios constitucionais de modo a exigir que se estabeleça o peso relativo de cada um dos direitos por meio da aplicação das máximas que integram o mencionado princípio da proporcionalidade. São três as máximas parciais do princípio da proporcionalidade: a adequação, a necessidade e a proporcionalidade em sentido estrito." Ibid.

${ }^{201}$ Classifico como "clichê" uma vez que é comum encontrarmos decisões judiciais que definem a liberdade de expressão como essencial, porém, não absoluta, uma vez que deve ser utilizada em harmonia com os demais direitos estabelecidos na Constituição de 1988. Desta forma, julgadores definem, genericamente, a liberdade de expressão como a mais abrangente possível, porém, esta constatação não é, na maioria dos casos, posta em prática.

SILVA, Priscilla Regina da. Os Limites Sagrados da Liberdade: uma análise do discurso de ódio contrarreligioso. Rio de Janeiro. Março de 2017. Dissertação em Pós-Graduação em Direito PUC-Rio. p. 162 
pluralista, da dignidade humana e o ônus imposto à liberdade de expressão do paciente. ${ }^{202}$ Porém, interessante ressaltar que, a partir da utilização do mesmo princípio da proporcionalidade, o ministro Marco Aurélio atingiu posição contrária, posicionando-se pela procedência do pedido de Habeas Corpus, por entender que, apesar de o livro de Ellwanger ser claramente preconceituoso, não se pode proibir a divulgação desta ideia, pois é a sociedade a responsável por realizar a escolha de suas próprias opiniões, em benefício do princípio democrático.

Embora seja o Caso Ellwanger importante para a jurisprudência brasileira, o mesmo apresenta algumas peculiaridades. ${ }^{203} \mathrm{Em}$ primeiro lugar, apesar do reconhecimento do caráter discriminatório das publicações, o julgamento não estipula padrões de análise para casos futuros que envolvam discriminação e discurso de ódio, pois os ministros utilizaram-se de fundamentações distintas sobre a mesma matéria, indicando uma análise mais particularista, por meio de avaliação casuística, não preocupada com a formação de precedentes e standards para utilização futura. Pela simples leitura do acordão, não há como definir se a condenação ocorreu em razão da negativa do Holocausto e, por isso, sempre que o mesmo fato ocorrer ele deve ser interpretado como proibido no Brasil, ou se a condenação por racismo ocorreu pela forma do discurso, isto é, através da publicação de livros. ${ }^{204}$

Além disso, a partir do julgamento, há a confirmação de existência de confusão entre a conceituação de discurso de ódio e racismo, utilizados como sinônimos pelos ministros, que não se posicionaram sobre a universalização do uso do termo "raça", de forma a abranger qualquer

\footnotetext{
202 OMMATI, José Emílio Medauar. Liberdade de Expressão e Discurso de ódio na Constituição de 1988. $3^{\text {a }}$ Ed. Rio de Janeiro: Lumen Juris Direito, 2016. p. 51.

${ }^{203}$ Os ministros envolvidos na decisão do referido $\mathrm{HC}$ não possuíam indicação sobre o que seria discurso de ódio, apesar de o Tribunal entender que o que foi realizado por Ellwanger seria um dos casos de discurso de ódio. Além disso, embora a decisão tenha sido tomada com base em maioria significativa, os ministros não concordam nas razões de seus votos, cada qual utilizando fundamentação distinta dos demais.

${ }^{204}$ SILVA, Priscilla Regina da. Os Limites Sagrados da Liberdade: uma análise do discurso de ódio contrarreligioso. Rio de Janeiro. Março de 2017. Dissertação em Pós-Graduação em Direito PUC-Rio. p. 157-158.
} 
grupo social passível de ser identificado e subjugado por razões históricas e sociais, ou se tal entendimento estaria apenas restrito ao judaísmo. ${ }^{205}$

O julgamento deste caso revela também a tendência dos tribunais brasileiros de dar maior prevalência aos direitos da personalidade e ao princípio da dignidade humana quando confrontados pela liberdade de expressão, mesmo após exposição padrão a respeito da importância deste direito, principalmente na concretização de um Estado Democrático. O argumento básico utilizado, como feito pelo ministro Gilmar Mendes, é de que a liberdade de expressão não pode ser considerada "absoluta", sendo deixada de lado após o exercício da ponderação de interesses, que muitas vezes atua como instrumento de esvaziamento deste direito em prol dos direitos da personalidade. ${ }^{206}$

Caso similar ao HC 82.424-2/RS, também abrangendo a discussão acerca da divulgação de ideias referentes ao Holocausto, envolveu a escola de samba carioca Unidos do Viradouro. Ao adotar o tema "É de arrepiar" para o desfile do ano de 2008, com intenção de retratar assuntos que causam medo e arrepio, a escola de samba tinha intenção de levar à avenida carro alegórico a respeito do Holocausto, representado por vários cadáveres nus empilhados e um integrante vestido de Hitler sobre os corpos.

Após pedido liminar da Federação Israelita do Rio de Janeiro (Fierj), a $33^{\mathrm{a}}$ Vara Cível do Rio de Janeiro concedeu liminar que determinou a proibição do desfile do referido carro alegórico, sob pena de multa de $\mathrm{R} \$ 200.000,00$ (duzentos mil reais) e mais $\mathrm{R} \$ 50.000,000$ (cinquenta mil) caso alguém estivesse caracterizado de Adolf Hitler. ${ }^{207}$ A decisão baseou-se no pressuposto de que o Carnaval não poderia ser utilizado como

\footnotetext{
${ }^{205}$ Ibid. p. 158.

206 CHEQUER, Cláudio. A Liberdade de Expressão como Direito Fundamental Preferencial Prima Facie: (análise crítica e proposta de revisão ao padrão jurisprudencial brasileiro). Rio de Janeiro: Lumen Juris, 2011. p. 206-208.

207 33 ${ }^{\mathrm{a}}$ Vara Cível do Rio de Janeiro, Processo $\mathrm{n}^{\mathrm{o}}$ 0024517-86.2008.8.19.0001, Juíza Juliana Kalichszteim, Rio de Janeiro, 2008; Reuters. Justiça pró́be Viradouro de levar carro do Holocausto à Sapucaí. Rio de Janeiro, 31 de janeiro de 2008. Disponível em $<$ https://br.reuters.com/article/entertainmentNews/idBRN3157209520080131>. Acesso em 27 mar. 2018.
} 
ferramenta de ódio e de que a banalização de eventos bárbaros como o genocídio de cerca de 6 (seis) milhões de judeus era inaceitável. Interessante, no presente caso, analisar como a decisão não foi apta a diferenciar expressões artísticas, cujo intuito era a crítica aos fatos históricos ocorridos durante a Alemanha nazista, do que realmente constitui discurso de ódio e seus vieses de incitação a atos de violência, ódio e discriminação.

Outro caso emblemático na jurisprudência brasileira no tocante ao hate speech ocorreu em 1995, conhecido popularmente como "Chute na Santa Padroeira do Brasil". 208 Durante o programa "Palavra de Vida", transmitido ao vivo pela Rede Record de Televisão, o então bispo da Igreja Universal, Sergio von Helder, proferiu insultos e agressões verbais a outras religiões, além de chutar o símbolo religioso de Nossa Senhora Aparecida. Após condenação em primeira instância por violação ao art. 20 da Lei 7.716/89 e artigo 208 do Código Penal, o Tribunal de Justiça do Estado de São Paulo confirmou a violação do primeiro dispositivo ao considerar que a conduta do bispo foi semeadora de intolerância, ódio, desprezo, discriminação e preconceito em relação a católicos, a espíritas e a adeptos de seitas afro-brasileiras, de forma a extrapolar os limites da crítica e pregação religiosa. Para o relator, o mero perigo de lesão ao bem jurídico tutelado já seria suficiente para que o ato ilícito se concretizasse, independentemente da real constatação do induzimento dos espectadores a sentimentos discriminatórios e preconceituosos. Nota-se, mais uma vez, a utilização da ideia de racismo, através da aplicação da lei 7.716/89, e do termo "preconceito", como sinônimo de hate speech.

Caso similar, também sobre discurso de ódio religioso, ocorreu com base no livro “Orixás, Caboclos e Guias, deuses ou demônios?”, lançado em 1987, de autoria do bispo evangélico Edir Macedo, considerado, por si

\footnotetext{
${ }^{208}$ TJSP, Apelação Criminal no 238.705.3/0, Rel. Geraldo Xavier, São Paulo, 10 nov. 1999.
} 
mesmo, um especialista em "demonologia". ${ }^{209} \mathrm{Na}$ referida obra, o autor acusa religiões de matriz africana, o kardecismo e o catolicismo de serem utilizadas pelo diabo como forma de enganar o povo, culpando-as pela origem de doenças, desavenças e diversos outros males do mundo. Apesar de Edir Macedo não incitar diretamente a agressão física aos umbandistas, por exemplo, é possível que alguns leitores se sintam tendentes à prática destes atos devido ao tom violento do documento. ${ }^{210}$

Por estes motivos, em 2005, o Ministério Público Federal ajuizou ação civil pública (processo $n^{\circ} 200501000696058$ ) contra a publicação, sob a alegação de violação do art. 20 da Lei no 7.716/89. Em decisão liminar, a juíza da $4^{\mathrm{a}}$ Vara Federal da Bahia determinou a suspensão, em 30 dias, da venda do referido livro, sob pena de multa diária no valor de $\mathrm{R} \$ 50.000,00$ (cinquenta mil reais), além de sanções cíveis e criminais, por considerar o conteúdo da publicação como violador da liberdade de consciência e de crença das religiões de matriz africana e do direito à coexistência social pacífica da diversidade de credos. ${ }^{211}$ Com base nesta decisão de limitação à liberdade de expressão para a restrição de discurso de ódio, não há como definir se este entendimento firmado poderia ser utilizado para casos futuros semelhantes como, por exemplo, comentários potencialmente ofensivos e preconceitos de adeptos da religião evangélica contra

\footnotetext{
209 Interessante que, apesar do conteúdo das manifestações de Edir Macedo ser claramente contaminado pelo ódio por pessoas que professam religiões distintas da sua, o mesmo não acredita manifestar discurso de ódio. Ao contrário, o bispo considera pessoas de crenças diversas enganadas pelo demônio e ele estaria apto a auxiliá-las em seu processo de libertação. Embora as intenções do autor sejam em prol do bem comum, seu discurso religioso é coberto de intolerância, o que também ocorre no discurso de evangélicos a respeito da opção sexual de homossexuais, chamados à "cura". SILVA, Priscilla Regina da. Os Limites Sagrados da Liberdade: uma análise do discurso de ódio contrarreligioso. Rio de Janeiro. Março de 2017. Dissertação em PósGraduação em Direito - PUC-Rio. p. 166-168.

${ }^{210}$ DIAS, Julio César Tavares; CAMPOS, Zuleica Dantas Pereira. O Discurso de Intolerância da Igreja Universal do Reino de Deus: Uma Análise do Livro "Orixás, Caboclos e Guias". Goiânia: Fragmentos de Cultura, n. 4, 2012. Disponível em: $<$ http://seer.ucg.br/index.php/fragmentos/article/viewFile/2551/1584>. Acesso em 27 mar. 2018.

211 O Globo. Juíza suspende venda de livro do bispo Edir Macedo. Salvador, 10 de novembro de 2005. Disponível em <http://wwwl.folha.uol.com.br/folha/cotidiano/ult95u115122.shtml $>$. Acesso em 27 mar. 2018.
} 
homossexuais. ${ }^{212}$ Além disso, não houve comentário na decisão de primeira instância a respeito das consequências efetivas da retirada do conteúdo de circulação, anos após a primeira publicação, que já somava mais de 4 milhões de exemplares vendidos - o que foi feito apenas um ano após a liminar, em sede de agravo de instrumento, quando o Tribunal Regional Federal da $1^{\mathrm{a}}$ Região retirou a suspensão das vendas, ao considerar que a proibição violava o direito da liberdade de expressão. ${ }^{213}$

Além do incitamento ao ódio contra certos tipos de religião, raça ou gênero, nos últimos anos, o Brasil vem enfrentando o crescimento do hate speech em razão de posicionamento político, principalmente por meio de redes sociais. Exemplo claro deste cenário ocorreu em 2010, após a primeira eleição da ex-presidente Dilma Roussef, quando o Ministério Público Federal denunciou a estudante de Direito Mayara Petruso pelo crime de discriminação ou preconceito de procedência nacional, com base no art. 20 da Lei 7.716/89, por publicar na rede social Twitter o seguinte discurso: "Nordestino não é gente. Faça um favor a SP: mate um nordestino afogado". Ela foi condenada pela $9^{\text {a }}$ Vara Federal Criminal de São Paulo a um ano e cinco meses de reclusão, convertida em prestação de serviços comunitários e pagamento de multa. ${ }^{214}$

O preconceito e a discriminação contra nordestinos ganham a forma de discurso de ódio enraizado em parte da população brasileira, o que pode ser percebido da repetição similar dos fatos, em 2014, após a reeleição de Dilma Roussef, com vitória expressiva nos nove estados do Nordeste, desencadeando em uma onda de ódio proferida contra nordestinos na

212 SILVA, Priscilla Regina da. Os Limites Sagrados da Liberdade: uma análise do discurso de ódio contrarreligioso. Rio de Janeiro. Março de 2017. Dissertação em Pós-Graduação em Direito PUC-Rio. p. 166-168.

${ }^{213}$ UOL (A Tarde). Justiça libera venda de livro de Edir Macedo. Salvador, 26 de setembro de 2006. Disponível em <http://atarde.uol.com.br/bahia/salvador/noticias/1266396-justica-liberavenda-de-livro-de-edir-macedo $>$. Acesso em 09 mai. 2018;

SILVA, Priscilla Regina da. Os Limites Sagrados da Liberdade: uma análise do discurso de ódio contrarreligioso. Rio de Janeiro. Março de 2017. Dissertação em Pós-Graduação em Direito PUC-Rio. p. 166.

${ }^{214}$ G1. Jovem é condenada por mensagem contra nordestinos no Twitter. São Paulo, 15 de maio de 2012. Disponível em <http://g1.globo.com/sao-paulo/noticia/2012/05/condenada-estudante-quepublicou-mensagem-contra-nordestinos-em-sp.html>. Acesso em 28 mar. 2018. 
Internet, considerados "culpados" pelas mazelas do país. Dentre os discursos proferidos havia o desejo de que a região fosse tomada pela desnutrição, de que seus bebês nascessem acéfalos e que todos fossem mortos pelo vírus ebola, além de ameaças de agressões físicas e assassinato. $^{215}$

Além dos casos já citados, o discurso de ódio é frequentemente dirigido contra grupos determinados por sua orientação sexual, principalmente homossexuais. Neste contexto, o deputado federal Jair Bolsonaro teve, em 2017, condenação em ação civil pública confirmada pela $6^{\text {a }}$ Câmara Cível do Tribunal de Justiça do Rio de Janeiro no valor de $\mathrm{R} \$ 150.000,00$ (cento e cinquenta mil reais) a título de dano moral coletivo por declarações homofóbicas. Os fatos ocorreram em 2011 durante a participação do deputado federal no programa CQC da TV Bandeirantes, quando referiu-se a pessoas homossexuais como "boiolas", afirmando que "ninguém tem orgulho de ter um filho gay ou uma filha lésbica", além de declarar que não teria "o risco" de ter um filho homossexual em razão da boa educação dedicada aos filhos e por ter sido "um pai presente". O TJRJ negou a alegação do réu de imunidade parlamentar por qualificar a fala do deputado como alheia ao exercício da função legislativa, por ser exteriorização de ideia de inferioridade, humilhação e inadequação social e moral daqueles que possuem orientação sexual diferente da sua, a qual defende ser a única correta. ${ }^{216}$

Não foi a primeira condenação de Jair Bolsonaro por discursos odiosos. Em abril de 2017, o deputado federal realizou palestra junto ao Clube Hebraica RJ, onde proferiu frases, segundo o Ministério Público

\footnotetext{
${ }^{215}$ R7. Ódio contra eleitores nordestinos deve passar logo. Rio de Janeiro, 28 de outubro de 2018. Disponível em <https://noticias.r7.com/eleicoes-2014/odio-contra-eleitores-nordestinos-devepassar-logo-28102014>. Acesso em 28 mar. 2018; Terra. Nordestinos são hostilizados após vitória de Dilma Roussef. Disponível em <https://www.terra.com.br/noticias/eleicoes/nordestinos-saohostilizados-apos-vitoria-de-dilmarousseff,aa13fc86bd059410VgnVCM5000009ccceb0aRCRD.html>. Acesso em 28 mar. 2018. ${ }^{216} 6^{\text {a }}$ Câmara Cível do TJRJ. Apelação Cível $\mathrm{n}^{\circ}$ 0115411-06.2011.8.19.0001. Rel. Inês da Trindade Chaves de Melo. Rio de Janeiro, 08 de novembro de 2017. Disponível em $<$ http://www1.tjrj.jus.br/gedcacheweb/default.aspx?UZIP=1\&GEDID=0004FF763E09038C86205 C99064368E3D1E1C5072018010D>. Acesso em 28 mar. 2018.
} 
Federal, de conteúdo racista, misógino e xenófobo contra as comunidades quilombolas e a população negra em geral, através de frases como:

(...) eu fui num quilombola em eldorado paulista, olha, o afrodescendente mais leve lá pesava sete arrobas... Não fazem nada, eu acho que nem pra procriador servem mais. Mais de um bilhão de reais por ano gastados com eles, recebem cesta básica e mais, material, implementos agrícolas (...). ${ }^{217}$

Assim como no caso anterior, a juíza federal negou provimento à alegação do réu de imunidade parlamentar, condenando-o ao pagamento de $\mathrm{R} \$ 50.000,00$ (cinquenta mil reais), a título de danos morais, pelo proferimento de discurso estranho ao exercício do mandato legislativo que ofendia, ridicularizava e constrangia o grupo de quilombolas e a população negra em geral. Além disso, estabeleceu a decisão que Jair Bolsonaro, como representante público, teria o dever de respeito a seus cidadãos, pois, uma vez eleito, passou a ser representante de toda a coletividade, sem distinção.

\subsection{Entendimentos retirados do cenário brasileiro atual}

Após análise da jurisprudência brasileira quanto ao discurso de ódio, nota-se a tendência de julgamento contrário aos discursos odiosos, aproximando-se do posicionamento firmado pelo Sistema Europeu de Direitos Humanos. No entanto, ao mesmo tempo, fica clara a ausência de parâmetros judiciais para utilização em casos concretos semelhantes e futuros, pois, geralmente, a avaliação realizada é apenas casuística, o que é agravado pela inexistência de legislação específica que regule o tema.

A falta de parâmetros de julgamento existe, em parte, em razão da grande abstração e generalidade dos valores e princípios constitucionais em conflito, de forma que o conteúdo da Constituição passa a ser definido

\footnotetext{
${ }^{217} 26^{\mathrm{a}}$ Vara Federal da Seção Judiciária do Rio de Janeiro. Ação Civil Pública n ${ }^{\text {o }}$ 010129870.2017.4.02.5101. Juíza federal Frana Elizabeth Mendes. 25 de setembro de 2017.
} 
casuisticamente, a partir da justiça do caso concreto. ${ }^{218}$ Sendo assim, o que ocorre é a presença do "particularismo jurídico", 219 que, segundo Cass Sunstein, proporciona a criação de decisões superficiais e amplas, preocupadas em resolver apenas um caso específico, sem solucionar a problemática principal ou outras que possam surgir. ${ }^{220}$

A falta de legislação específica a respeito do discurso de ódio, constantemente utilizado como sinônimo de racismo ou discriminação, a partir da aplicação do art. 20 da Lei 7.716/89, também pode ser considerada uma das razões da abstração nas decisões judiciais. Sob os padrões estipulados pelo Rabat Plan of Action, esta forma de regulação do hate speech é extremamente abrangente e vaga, descumprindo as definições internacionais. Com isso, há possibilidade de aplicação de forma arbitrária pelo julgador, que pode decidir casos semelhantes de forma diversa. A partir desse cenário, podemos verificar um efeito encorajador para que sejam ajuizadas, cada vez mais, ações judiciais, pois, com a falta de critérios sólidos de decisão, sempre é possível argumentar a favor de sua pretensão. $^{221}$

Além disso, o cenário social brasileiro é de crescimento do discurso de ódio direcionado a grupos minoritários, historicamente discriminados, o que foi intensificado principalmente com o advento da Internet e o uso das redes sociais. Apesar de o povo brasileiro ser tradicionalmente conhecido por sua cordialidade e hospitalidade, esta constatação não é propagada nas

\footnotetext{
${ }^{218}$ SILVA, Priscilla Regina da. Os Limites Sagrados da Liberdade: uma análise do discurso de ódio contrarreligioso. Rio de Janeiro. Março de 2017. Dissertação em Pós-Graduação em Direito PUC-Rio. p. 175-179.

${ }^{219}$ Também conhecido como "minimalismo decisório". Opõe-se ao formalismo jurídico. É quando a decisão é tomada pelo julgador apenas atendo-se ao caso concreto, sem preocupar-se com casos futuros e a formação de precedentes. LEITE, Fábio Carvalho. Liberdade de Expressão e Direitos da Personalidade: (Novos) Fundamentos para a posição preferencial da Liberdade de Expressão nos conflitos com o direito à honra e à imagem, 2015;

SCHAUER, Frederick. Thinking Like a Lawyer: A New Introduction to legal Reasoning. London: Harvard University Press, 2009. p. 188-202.

${ }^{220}$ SUNSTEIN, Cass. R. Beyond Judicial Minimalism. Chicago: University of Chicago Law School, 43 Tulsa Law Review 825. 2007. p. 826.

${ }^{221}$ SILVA, Priscilla Regina da. Os Limites Sagrados da Liberdade: uma análise do discurso de ódio contrarreligioso. Rio de Janeiro. Março de 2017. Dissertação em Pós-Graduação em Direito PUC-Rio. p. 177.
} 
comunidades virtuais do país. Entre abril e junho de 2016, um algoritmo vasculhou plataformas como o Facebook, Twitter e Instagram em busca de mensagens e textos sobre temas sensíveis, como o racismo, posicionamento político e homofobia, com a identificação de 393.284 marcações e, dentre estas, $84 \%$ possuíam exposição de preconceito e discriminação. ${ }^{222}$

A frustração com o sistema em geral faz com que as pessoas busquem soluções antidemocráticas e autoritárias, e consequentemente, há a criação do discurso de ódio, com empobrecimento da informação. ${ }^{223} \mathrm{~A}$ cientista social e docente da Universidade Federal de São Paulo Esther Solano sustenta que o país possui "dinâmica de classe perversa", com elites econômicas e políticas ao lado de massa social extremamente empobrecida, o que proporciona o discurso de ódio, principalmente, contra partidos de esquerda e movimentos sociais.

Este aumento é justificado também pela intensa polarização de ideias políticas, principalmente após escândalos de corrupção e crise econômica, tal como nos ataques cibernéticos contra nordestinos após vitória do PT nas eleições presidenciais, anteriormente mencionados. ${ }^{224}$ Nesse contexto, segundo a cientista social, a internet pode ser uma plataforma democrática poderosa, porém, proporciona também a criação de filter bubble ${ }^{225}$ [filtros-

\footnotetext{
222 Dados produzidos pelo projeto "Comunica que Muda" de iniciativa da Agência Nova/SB. Dentre o total de mensagens, 219.272 tinham viés político, com 97,4\% de abordagem negativa; 49.544 citações tratavam a temática da mulher, sendo $88 \%$ com características de intolerância, como manifestações de assédio, pornografia de vingança, incitação ao estupro e outras violências, por vezes travestidas de "piadas"; 40.801 mensagens eram a respeito de pessoas portadoras de deficiência, com 93,4\% de abordagem negativa, a partir da utilização de termos como "leproso" e "retardado mental"; o racismo também destacou-se com um total de 17.026 menções, dentre elas, $97,6 \%$ negativas. O Estado com maior incidência de mensagens de ódio e intolerância foi o Rio de Janeiro, com 58.284 mensagens.

O Globo. Brasil cultiva discurso de ódio nas redes sociais, mostra pesquisa. 03 de agosto de 2016. Disponível em <https://oglobo.globo.com/sociedade/brasil-cultiva-discurso-de-odio-nas-redessociais-mostra-pesquisa-19841017>. Acesso em 29 mar. 2018.

${ }^{223}$ SODRÉ, Lu. A intolerância sai do armário, chega às ruas e se propaga na internet. São Paulo: Entreteses (Revista da Universidade federal de São Paulo - UNIFESP), Edição de 2017. Disponível em: <http://www.unifesp.br/reitoria/dci/entreteses/item/2584-a-intolerancia-sai-doarmario-chega-as-ruas-e-se-propaga-na-internet>. Acesso em 29 mar. 2018.

${ }^{224}$ Vide item 3.1.

${ }^{225} \mathrm{O}$ conceito de filter bubble foi pensado por Eli Pariser. Através de um conjunto de dados gerados por mecanismos algorítmicos de provedores de internet, realiza-se uma espécie de personificação dos conteúdos online, a partir das características de navegação de cada pessoa, de forma a gerar uma "segregação", como se o indivíduo estivesse em uma "bolha" na qual recebe
} 
bolha ou bolhas de informação], com o consequente acesso apenas à posição ideológica do grupo ao qual o indivíduo pertence, dificultando o debate com aquele que possui opinião contrária. Para Solano:

Aquele que tem uma opinião política diferente não é um adversário político, é um inimigo. É a política do ódio. Com o adversário político há uma troca de ideias, com inimigo não. O objetivo é aniquilá-lo. Aniquilar o pensamento, a voz. É uma dinâmica de guerra. ${ }^{226}$

A filtragem de informações, realizada pelos provedores e sites de internet, apesar de ter o comodismo como razão inicial, estaria transformando o ambiente online em um espaço onde é mostrado - a partir de algoritmos - apenas o que se entende como interesse de determinado usuário, ocultando o que é entendido como aquilo que não lhe convém saber. Ademais, com o aumento da popularidade das mídias sociais, é facilitada a busca e compartilhamento voluntário de ideias com outras pessoas com interesses e valores semelhantes. ${ }^{227}$ Desta forma, há enorme prejuízo para o debate democrático na esfera pública, uma vez que o indivíduo se restringe à sua posição ideológica, muitas vezes repleta de ódio ou inverdades - há a possibilidade de relacionar-se somente com pessoas

\footnotetext{
apenas informações compatíveis com seu perfil e, aquelas que não o são, lhe são ocultadas. A problemática desta questão encontra-se no fato de que não é o indivíduo que decide o que aparecerá dentro da bolha nem se terá acesso ao que fica de fora.

MAGRANI, Eduardo. Democracia conectada: a internet como ferramenta de engajamento político-democrático. Juruá: Rio de Janeiro, 2014. p. 118-122. Disponível em: $<$ http://bibliotecadigital.fgv.br/dspace/handle/10438/14106>. Acesso em 10 mai. 2018.

${ }^{226}$ SODRÉ, Lu. A intolerância sai do armário, chega às ruas e se propaga na internet. São Paulo: Entreteses (Revista da Universidade federal de São Paulo - UNIFESP). 2017. Disponível em: $<$ http://www.unifesp.br/reitoria/dci/entreteses/item/2584-a-intolerancia-sai-do-armario-chega-asruas-e-se-propaga-na-internet>. Acesso em 29 mar. 2018.

Exemplo claro para isto foi a colocação de um muro na Esplanada dos Ministérios, em Brasília, para a votação do impeachment da ex-presidente Dilma Roussef, com o intuito de evitar conflitos entre aqueles que eram a favor e contra o processo.

Correio do Povo. Especialistas analisam ódio em meio à polarização política. 04 de abril de 2016. Disponível em <http://www.correiodopovo.com.br/Noticias/Politica/2016/4/584517/Especialistasanalisam-odio-em-meio-a-polarizacao-politica>. Acesso em 29 mar. 2018.

227 MAGRANI, Eduardo. Democracia conectada: a internet como ferramenta de engajamento político-democrático. Juruá: Rio de Janeiro, 2014. p. 118-125. Disponível em: $<$ http://bibliotecadigital.fgv.br/dspace/handle/10438/14106>. Acesso em 10 mai. 2018.
} 
que são contra os mesmos ideais políticos e que pensam e odeiam de forma semelhante, facilitando a polarização, o extremismo e a violência. ${ }^{228}$

Com a proximidade das eleições presidenciais de 2018, neste cenário de polarização política e crescimento do discurso de ódio, houve uma pequena reforma no ordenamento político eleitoral. A redação final do Projeto de Lei $\mathrm{n}^{\mathrm{o}}$ 8.612-B de 2017 possuía dispositivo - art. 57-B, §6 $6^{\circ}$, incluído de última hora em votação relâmpago, considerado censura e grave ameaça ao regime democrático por entidades ligadas à imprensa e pela ONG Artigo 19,229 uma vez que possibilitava a suspensão, sem ordem judicial, de publicação que contivesse discurso de ódio, disseminação de informações falsas ou ofensa em desfavor de partido ou candidato, a partir de denúncia por usuário de aplicativo ou rede social na internet, por meio de canal disponibilizado para este fim no próprio provedor. A suspensão deveria ocorrer dentro do prazo máximo de 24 horas e perduraria até que este se certificasse da identificação pessoal do usuário responsável pela publicação. ${ }^{230}$

A Associação Brasileira de Emissoras de Rádio e Televisão (Abert), a Associação Nacional de Editores de Revistas (Aner) e a Associação Nacional de Jornais (ANJ) consideraram que o dispositivo feria o Marco Civil da Internet, art. 19, ${ }^{231}$ que determina a retirada ou suspensão de conteúdo disponibilizado na internet apenas por meio de decisão judicial, de

\footnotetext{
${ }^{228}$ Ibid. p. 126;

SUSTEIN, Cass. Republic.com 2.0. Nova Jersey: Princeton University Press, 2007. p. 65-96.

${ }^{229}$ Artigo 19. ARTIGO 19 repudia emenda que legaliza censura nas eleições brasileiras. 06 de outubro de 2017. Disponível em <http://artigo19.org/blog/2017/10/06/artigo-19-repudia-emendaque-legaliza-censura-nas-eleicoes-brasileiras/>. Acesso em 29 mar. 2018.

${ }^{230}$ Redação final do Projeto de Lei $\mathrm{n}^{\circ}$ 8.612-B de 2017. Disponível em $<$ https://www.poder360.com.br/wp-content/uploads/2017/10/5out-redacao-final-PL-8612-

2017.pdf>. Acesso em 29 mar. 2018.

O Globo. Entidades ligadas à imprensa criticam emenda que permite censura eleitoral na internet. 05 de outubro de 2017. Disponível em <https://oglobo.globo.com/brasil/entidades-ligadasimprensa-criticam-emenda-que-permite-censura-eleitoral-na-internet-21914725>. Acesso em 29 mar. 2018.

${ }^{231}$ Dispõe o art. 19 do Marco Civil da Internet (lei 12.965/2014): "com o intuito de assegurar a liberdade de expressão e impedir a censura, o provedor de aplicações de internet somente poderá ser responsabilizado civilmente por danos decorrentes de conteúdo gerado por terceiros se, após ordem judicial específica, não tomar as providências para, no âmbito e nos limites técnicos do seu serviço e dentro do prazo assinalado, tornar indisponível o conteúdo apontado como infringente, ressalvadas as disposições legais em contrário.".
} 
forma a preservar a liberdade de expressão e impedir a censura. A ONG Artigo 19, em repúdio à emenda, salientou que caso o Judiciário fosse destituído do poder de decidir pela remoção ou não de conteúdos da internet, as chances da ocorrência de abusos, como a solicitação de remoção de conteúdos legítimos, seriam elevadas, uma vez que o papel de juiz seria transferido para empresas, que optariam pela remoção dos conteúdos o mais rápido possível, a fim de evitar ações judiciais e perdas econômicas.

Após a repercussão negativa da emenda que incluía o art. 57-B, $\S 6^{\circ}$, o deputado Áureo do SD-RJ, autor da mesma, arrependeu-se do teor proposto, vindo a afirmar que pediria ao presidente Michel Temer que vetasse o referido trecho, por este ter sido mal interpretado, necessitando de maior discussão com a sociedade. De fato, o projeto de lei, sancionado na Lei $\mathrm{n}^{\mathrm{o}} 13.488 / 2017$, atualmente em vigor, possui o veto presidencial no referido dispositivo. ${ }^{232} \mathrm{Em}$ meio a este cenário conturbado, o posicionamento tomado pelo presidente foi acertado, em benefício da proteção da liberdade de expressão e em concordância com os padrões internacionais, que recomendam a não criação de regulamentações do discurso de ódio que possam ser facilmente manipuladas por determinado grupo social, em seu próprio benefício, como era o caso do art. 57-B, $\S 6^{\circ}$.

Ademais, com a crise política e econômica, também passamos a conhecer o discurso de ódio a partir da divulgação de Fake News [notícias falsas $]^{233}$, que podem ser declarações ambíguas, enviesadas, enganosas ou derivadas de enganos que, na prática, são equiparáveis a mentiras inventadas pelos mais variados motivos, dentre eles: ganhar dinheiro, alcançar resultados eleitorais, formar e influenciar correntes de opinião,

${ }^{232} \mathrm{O}$ Globo. Temer sanciona reforma política com veto a censura na internet. 06 de outubro de 2017. Disponível em <https://oglobo.globo.com/brasil/temer-sanciona-reforma-politica-com-vetocensura-na-internet-21919897>. Acesso em 29 mar. 2018.

${ }^{233}$ Pode-se considerar que as "fake news" existem há muito tempo, desde o início da circulação de notícias, após a criação da imprensa em 1439. A definição restrita entende esta expressão como notícias que são intencionalmente e verificadamente falsas, aptas a enganar leitores. A partir deste conceito, nota-se dois elementos para a qualificação das fake news: a existência de notícias falsas que podem ser verificadas como tal e a intenção desonesta de enganar os leitores.

SHU Kai et al.. Fake News Detection on Social Media: A Data Mining Perspective. 2017. Disponível em $<$ https://arxiv.org/pdf/1708.01967.pdf>. Acesso em 10 mai. 2018. 
induzir metas de políticas públicas e reforçar vínculos de informações coletiva, de forma a formatar maneiras de pensar e sentir em determinados segmentos sociais. $^{234}$

A divulgação das fake news acontece, principalmente, através das redes sociais, onde a replicação de informações ocorre em velocidade incomparável às mídias tradicionais. ${ }^{235}$ Além do uso intensivo destas, 120 milhões de brasileiros comunicam-se por meio de WhatsApp, onde notícias falsas ou tendenciosas circulam imunes a qualquer tentativa de checagem de sua veracidade, de forma a proporcionar a criação de bolhas de informações. Em um cenário, como o brasileiro, repleto de polarização e ódio político contra determinados grupos sociais, a proliferação destas notícias é facilitada. ${ }^{236}$

Desta forma, sendo esta uma questão recente, o Brasil não possui legislação ou orientação específica de combate às notícias falsas, como ocorre em alguns ordenamentos jurídicos internacionais, a exemplo do alemão, anteriormente mencionado. ${ }^{237} \mathrm{O}$ país é apenas signatário da Declaração de Chapultepec, carta de princípios internacionais que estabelece o compromisso da imprensa com a verdade. ${ }^{238}$ Todavia, a

\footnotetext{
${ }^{234}$ JÚNIOR, Owvaldo Giacoia. E se o erro e a fabulação do engano se revelarem tão essenciais quanto à verdade? Disponível em <http://www1.folha.uol.com.br/ilustrissima/2017/02/1859994ese-o-erro-a-fabulacao-o-engano-revelarem-se-tao-essenciais-quanto-a-verdade.shtml $>$. Acesso em 02 abr. 2018.

${ }^{235}$ BALEM, Isadora Forgiarini. O impacto das Fakenews e o Fomento dos Discursos de Ódio na Sociedade em Rede: a Contribuição da Liberdade de Expressão na Consolidação Democrática. Santa Maria, 2017. Disponível em <http://coral.ufsm.br/congressodireito/anais/2017/1-12.pdf > . Acesso em 02 abr. 2018.

236 Estadão. Brasil é terreno fértil à desinformação, dizem especialistas. Disponível em $<$ http://politica.estadao.com.br/noticias/geral,brasil-e-terreno-fertil-a-desinformacao-dizemespecialistas,70002213869>. Acesso em 02 abr. 2018.

${ }^{237}$ Vide item 2.2.1.

Deutsche Welle. Lei contra discurso de ódio na internet entra em vigor na Alemanha. Disponível em: $\quad<\mathrm{http}: / / \mathrm{m} . \mathrm{dw} . \mathrm{com} / \mathrm{pt}$-br/lei-contra-discurso-de-\%C3\%B3dio-na-internet-entra-em-vigor-naalemanha/a-41996447>. Acesso em 19 mar. 2018.

${ }^{238}$ Dispõe o princípio IX da Declaração de Chapultepec: “A credibilidade da imprensa está ligada ao compromisso com a verdade, à busca de precisão, imparcialidade e equidade e à clara diferenciação entre as mensagens jornalísticas e as comerciais. A conquista desses fins e a observância desses valores éticos e profissionais não devem ser impostos. São responsabilidades exclusivas dos jornalistas e dos meios de comunicação. Em uma sociedade livre, a opinião pública premia ou castiga.";

Associação Nacional de Jornais (NJ). Declaração de Chapultepec. Disponível em $<\mathrm{http} / / /$ www.anj.org.br/declaracao-de-chapultepec-2/>. Acesso em 10 mai. 2018.
} 
problemática do discurso de ódio difundido por meio de fake news possui também outras abordagens possíveis, encontradas para além do Direito, uma vez que este talvez, por si só, não seja suficiente para o controle desta nova situação. ${ }^{239}$

Existem algumas formas desenvolvidas para o combate às notícias falsas, dentre elas, web-literacy ${ }^{240}$ e fact-checking. ${ }^{241}$ A primeira seria uma medida a longo prazo, a partir do investimento em educação digital, apta a treinar indivíduos para distinguir fatos de falácias, evitando que conteúdos duvidosos sejam amplamente divulgados, levando-os a duvidar antes de compartilhar. $^{242}$ A segunda seria a checagem de notícias através da autorregulação, realizada pelos próprios jornalistas ou através de plataformas de denúncia a conteúdos duvidosos em sites da Internet, com o escopo de garantir a veracidade dos fatos, ${ }^{243}$ como já desenvolvido pelo Facebook e pelo Google. ${ }^{244}$

Exemplo mais recente de geração de notícias falsas ocorreu a partir do assassinato da vereadora do PSOL, Marielle Franco, juntamente com seu motorista, Anderson Pedro Gomes, em 14 de março de 2018. Através de plataformas como o Facebook, Google e Youtube, as fake news e o discurso

\footnotetext{
239 SIGAL, Ivan. Fake News and Fake Solutions. How Do We Build a Civics of Trust?, 2017. Disponível em <https://globalvoices.org/2017/03/17/fake-news-and-fake-solutions-how-do-webuild-a-civics-of-trust/>. Acesso em 15 mai. 2018;

SOUZA, Carlos Affonso; PADRÃO, Vinícius. Quem lê tanta notícia (falsa)? Entendendo o combate contra as "fake news", 2017. Disponível em: <https://feed.itsrio.org/quem-1\%C3\%AAtanta-not $\% \mathrm{C} 3 \% \mathrm{ADcia}$-falsa-entendendo-o-combate-contra-as-fake-news-70fa0db05aa5>. Acesso em 15 mai. 2018.

${ }^{240}$ OLOF, Sundin. Negotiations on information-seeking expertise: A study of web-based tutorials for information literacy. Lund: Journal of Documentation, 2008.

${ }^{241}$ GRAVES, Lucas; NYHAN, Brendan; REIFLER, Jason. Understanding Innovations in Journalistic Practice: A Field Experiment Examining Motivations for Fact-Checking. Volume 66, Issue 1. Oxford: Oxford Academic, Journal of Communication, 2016;

${ }^{242}$ SOUZA, Carlos Affonso; PADRÃO, Vinícius. Quem lê tanta notícia (falsa)? Entendendo o combate contra as "fake news", 2017. Disponível em: <https://feed.itsrio.org/quem-1\%C3\%AAtanta-not $\% \mathrm{C} 3 \% \mathrm{ADcia}$-falsa-entendendo-o-combate-contra-as-fake-news-70fa0db05aa5 $>$. Acesso em 15 mai. 2018.

${ }^{243}$ GRAVES, Lucas; NYHAN, Brendan; REIFLER, Jason. Understanding Innovations in Journalistic Practice: A Field Experiment Examining Motivations for Fact-Checking. Volume 66, Issue 1. Oxford: Oxford Academic, Journal of Communication, 2016.

${ }^{244}$ BBC. Facebook to Tackle Fake News With Educational Campaign, 2017. Disponível em $<$ http://www.bbc.com/news/technology-39517033>. Acesso em 15 mai. 2018;

BBC. Google News Lauches Fact Check Label, 2016. Disponível em $<$ http://www.bbc.com/news/technology-37657524>. Acesso em 15 mai. 2018.
} 
de ódio sobre a vida pessoal, história e atuação na política e na defesa de Direitos Humanos da vereadora alcançaram quase 20 milhões de pessoas, apenas na primeira semana após o ocorrido. Com a repercussão, familiares de Marielle já ajuizaram duas ações com pedidos de retirada de conteúdo e identificação dos ofensores. Uma delas foi movida na $47^{\mathrm{a}}$ Vara Cível do Tribunal de Justiça do Rio de Janeiro, ${ }^{245}$ contra a Google, para a retirada de cerca de 40 vídeos do Youtube com falsas notícias sobre a vereadora executada, identificados a partir de mais de 16 mil e-mails recebidos com denúncias de fake news. A juíza titular, em decisão liminar, determinou a retirada, no prazo de 72 horas, do conteúdo falacioso, sob pena de multa diária no valor de $\mathrm{R} \$ 1.000,00$ (mil reais), por acreditar que este feria a honra, moral e memória de Marielle. A segunda ação, movida contra o Facebook, também obteve concessão de medida liminar para a retirada, dentro do prazo de 24 horas, de publicações, posts e vídeos listados na inicial que ofendiam a intimidade, honra e imagem da vereadora, sob pena de multa no valor total de $\mathrm{R} \$ 500.000,00$ (quinhentos mil reais). ${ }^{246}$

Com a exposição feita, é clara a inadequação do Brasil aos padrões definidos por standards internacionais, dentre eles, a ONG Artigo 19 e o Rabat Plan of Action, além de pouca efetividade na utilização de métodos de fora do Direito que atuam na tentativa de evitar a proliferação de fake news. A ausência de padrões judiciais de decisão, a inexistência de regulamentação específica quanto ao discurso de ódio e o cenário social de polarização política e ampla divulgação de fake news através de redes sociais demonstram a necessidade de enquadramento aos entendimentos internacionais.

\subsection{Aplicação dos standards internacionais no contexto brasileiro}

\footnotetext{
$24547^{\mathrm{a}}$ Vara Cível do TJRJ. Processo $\mathrm{n}^{\mathrm{o}}$ 0066013-46.2018.8.19.0001. Juíza Marcia Correia Hollanda, 22 de março de 2018.

${ }^{246} 15^{\mathrm{a}}$ Vara Cível do TJRJ. Processo no 0070926-71.2018.8.19.0001. Juiz Jorge Jansen Couñago Novelle, 28 de março de 2018.
} 
Apesar de o Brasil ser signatário de diversos tratados e convenções internacionais de Direitos Humanos que estabelecem a liberdade de expressão e igualdade, conforme determinação dos Camden Principles, princípio $\mathrm{n}^{\circ} 1$, a falha ocorre, inicialmente, com a ausência de regulação estatal específica a respeito da proibição ao incitamento ao ódio, de forma restritiva, seguindo as determinações dos mencionados princípios e do Rabat Plan of Action. ${ }^{247}$

A partir da busca por soluções para a problemática do discurso de ódio, a criação de lei específica para determinar o conceito do termo, sua abrangência e requisitos para restrição da liberdade de expressão nesses casos é essencial, de maneira a regular de forma restritiva, a partir do pressuposto de que limitações precisam ser tomadas apenas como última ratio, em caso de não haver outro meio menos danoso de solução. Desta forma, a base legal de decisões judicias seria menos ampla, não limitada apenas por princípios constitucionais abrangentes e pelo art. 20 da Lei 7.716/89 - vago e inconsistente com as definições internacionais do discurso de ódio,$-{ }^{248}$ mas em conceitos pré-determinados por lei para a análise do caso concreto, de maneira a impedir a aplicação arbitrária.

Esta regulação deve estabelecer a diferenciação entre sanções penais, cíveis e administrativas, sendo a primeira apenas para hipóteses mais graves de violação de direitos fundamentais através da incitação ao ódio, somente em casos restritos, com o intuito de preservar a liberdade de expressão, priorizando a utilização de sanções civis - indenização pecuniária, direito de correção e resposta - e administrativas. Além disso, a imposição de restrições aos discursos, sempre de forma excepcional, deve seguir análise de diversos elementos, ${ }^{249}$ a serem determinados por lei, de modo a

\footnotetext{
${ }^{247}$ Vide item 2.3.

${ }^{248}$ Para isso, necessária a definição clara e estrita dos termos "ódio", "incitação", "violência" e "hostilidade", por exemplo, conforme conceitos estabelecidos nos Camden Principles.

${ }^{249}$ Dentre esses elementos, conforme exposto no item 2.3: (i) contexto social e político da época do discurso; (ii) posição e status do autor da fala na sociedade e para quem ele se dirige; (iii) intenção do agente, isto é, de acordo com o art. 20 do Pacto Internacional dos Direitos Civis e Políticos, a mera negligência ou imperícia não são suficientes para qualificar um ato como uma
} 
categorizar os tipos de declarações puníveis criminal, civil ou administrativamente e aquelas não sancionadas, por estarem no âmbito da tolerância. ${ }^{250}$ Desta forma, a utilização dos princípios da legalidade, proporcionalidade e necessidade para aplicação das restrições à liberdade de expressão, principalmente quanto às sanções aplicáveis por lei, seria facilitada.

A criação de legislação específica quanto ao discurso de ódio e suas variáveis seria a implementação da recomendação legislativa do Rabat Plan of Action, que, em caso de ser posta em prática, não poderá ser desacompanhada do implemento efetivo de leis internacionais, repressivas e preventivas, de combate ao incitamento ao ódio. Ademais, em cumprimento à recomendação jurisdicional, a aplicação dos standards internacionais em âmbito interno, através da positivação das sugestões, seria complemento necessário, facilitando a aplicação de determinado entendimento em casos concretos futuros e semelhantes, a partir de orientações legais fixas, com a reflexão de casos individuais de modo coletivo, de forma a garantir a maior previsibilidade e segurança jurídica das decisões. ${ }^{251}$

No entanto, a legislação específica quanto ao discurso de ódio não pode ser desenvolvida sem a devida cautela, uma vez que a liberdade de

"ofensa", mas a intenção de incitar ou defender a violência e o ódio; (iv) conteúdo e forma, onde a análise deve levar em consideração o grau de discurso provocativo e direto, além da forma, estilo e natureza dos argumentos; (v) extensão do discurso, o que abrange o alcance do mesmo, além do tamanho do público e o local de realização (público ou privado); (vi) probabilidade e iminência do discurso atingir a sua finalidade de incitar ações concretas contra um grupo alvo específico.

${ }^{250}$ A ONG Artigo 19 propôs uma escala de gravidade do discurso de ódio em três categorias: (i) discurso de ódio que deve ser proibido, como incitação direta e pública ao genocídio ou outras práticas discriminatórias que envolvam violações ao Direito Penal Internacional e qualquer defesa de ódio discriminatório que constitua incitamento, hostilidade ou violência contra grupos sociais; (ii) discurso de ódio que pode vir a ser proibido, quando preenche o "teste das três partes", em outras palavras, a restrição deve basear-se em lei, criada por um fim legítimo e deve ser necessária em uma sociedade democrática; (iii) "discurso de ódio" legal, isto é, quando a expressão é inflamatória ou ofensiva, mas não atinge as determinações dos outros dois pontos, uma vez que não são graves o suficiente para justificar a limitação da liberdade de expressão.

ARTICLE 19. 'Hate Speech' Explained: A Toolkit. 2015 Ed. Disponível em $<$ https://www.article19.org/data/files/medialibrary/38231/'Hate-Speech'-Explained---A-Toolkit\%282015-Edition\%29.pdf>. Acesso em 02 abr. 2018.

${ }^{251}$ SILVA, Priscilla Regina da. Os Limites Sagrados da Liberdade: uma análise do discurso de ódio contrarreligioso. Rio de Janeiro. Março de 2017. 205p. Dissertação em Pós-Graduação em Direito - PUC-Rio. p. 178-179. 
expressão, um dos pilares do Estado Democrático de Direito, não deve tornar-se refém das doutrinas morais majoritárias e das concepções de "politicamente correto" de determinado período histórico. ${ }^{252}$ Sendo assim, a referida lei, criada sob os padrões internacionais, não pode conter falhas a ponto de transformar-se em instrumento de abuso e usurpação por seus criadores ou aplicadores, com intuito de evitar o surgimento do slippery slope, isto é, a ampliação da margem proibitiva até o momento em que a sociedade se encontrará suprimida de sua liberdade. ${ }^{253}$ Por este motivo é tão importante a delimitação legal de forma restritiva, de acordo com os mandamentos internacionais, preocupados em compatibilizar a liberdade de expressão e a igualdade, essenciais, conjuntamente, para a garantia da dignidade humana.

No mesmo sentido, deve haver a preocupação com a ampla divulgação de ideias variadas através do exercício da liberdade de expressão, com o impedimento do uso exacerbado de restrições pelos Tribunais, o que levaria ao enfraquecimento do debate público, uma vez que os cidadãos e a imprensa deixariam de expressar opiniões, inclusive aquelas de interesse público, pelo receito de responderem por sanções cíveis e criminais, a partir de uma "autocensura" conhecida como chilling effect. ${ }^{254}$ Para evitar o desenvolvimento deste fenômeno, a legislação específica quanto ao hate speech deve trazer as condenações criminais como última opção de solução, além de estipular critérios restritos, capazes

\footnotetext{
${ }^{252}$ SARMENTO, Daniel. A Liberdade de Expressão e o Problema do Hate Speech. Rio de Janeiro, 2006. Disponível em <http://www.dsarmento.adv.br/content/3-publicacoes/18-a-liberdade-deexpressao-e-o-problema-do-hate-speech/a-liberdade-de-expressao-e-o-problema-do-hate-speechdaniel-sarmento.pdf>. Acesso em 02 abr. 2018.

${ }^{253}$ LODE, Eric. Slippery Slope Arguments and Legal Reasoning. California Law: Review, vol. 87, issue $6, \quad 1999 . \quad$ Disponível em $<$ https://scholarship.law.berkeley.edu/cgi/viewcontent.cgi?article=1535\&context=californialawrev iew>. Acesso em 02 abr. 2018.

${ }^{254}$ TOLLER, Fernando M. O formalismo na liberdade de expressão: discussão da diferenciação entre restrições prévias e responsabilidades ulteriores. Tradução de Frederico Bonaldo. São Paulo: Saraiva, 2010.
} 
de, facilmente, qualificar um discurso como passível de restrição apenas nas hipóteses legalmente definidas. ${ }^{255}$

Outrossim, com a possível existência de uma legislação eficiente de combate aos discursos odiosos, é necessário salientar que ela, por trazer hipótese de limitação da liberdade de expressão, não pode ser banalizada. Dentro desta lógica, não deve haver espaço para que os tribunais realizem desconstruções das manifestações de expressão, com intuito de encontrar preconceitos e mensagens discriminatórias ocultas, uma vez que apenas discursos explícitos de ódio, preconceito e intolerância capazes de incitar atos de discriminação e violência devem ser considerados possíveis alvos de restrição legal. ${ }^{256}$

Contudo, a mera proibição do hate speech, através da criação de legislação específica e implemento judicial, de acordo com as determinações do Direito Internacional dos Direitos Humanos, não é suficiente para resolver os problemas de injustiça estrutural e a falta de reconhecimento social que atingem as minorias, ${ }^{257}$ vítimas de preconceito e discriminação historicamente enraizados, o que proporciona a divulgação facilitada de fake news e discurso de ódio. Desta forma, além das sugestões de teor legislativo e judicial, o cenário brasileiro necessita do implemento de ações afirmativas e políticas públicas educacionais efetivas que estimulem a consciência social, tolerância e debate público, de forma a criar e fortalecer uma cultura de paz e respeito mútuo, além do ensino voltado para os Direitos Humanos, com a consequente inclusão de minorias e

\footnotetext{
${ }^{255}$ A Artigo 19 percebe dois principais problemas com leis sofre o discurso de ódio que não seguem os padrões internacionais: (i) utilização destas por poderosos para incitar a violência impunimente, quando deveriam estar respondendo por isso; (ii) utilização das leis de forma abusiva para perseguir dissidentes legítimos, quando seus discursos deveriam estar protegidos por elas.

NEXO. Quando é justificável proibir um discurso, segundo esta ONG. 28 de agosto de 2017. Disponível em <https://www.nexojornal.com.br/entrevista/2017/08/22/Quando-\%C3\%A9justific\%C3\%A1 vel-proibir-um-discurso-segundo-esta-ONG>. Acesso em 02 abr. 2018.

${ }^{256}$ SARMENTO, Daniel. A Liberdade de Expressão e o Problema do Hate Speech. Rio de Janeiro, 2006. Disponível em <http://www.dsarmento.adv.br/content/3-publicacoes/18-a-liberdade-deexpressao-e-o-problema-do-hate-speech/a-liberdade-de-expressao-e-o-problema-do-hate-speechdaniel-sarmento.pdf>. Acesso em 02 abr. 2018.

${ }^{257}$ Ibid.
} 
eliminação de formas discriminatórias e estereotipadas, garantindo a liberdade de expressão por todos os setores da sociedade.

Ademais, é preciso investir em educação digital para que os indivíduos se tornem aptos a reconhecer casos de discurso de ódio travestidos de divulgação de notícias falsas, de forma a criar o hábito também de reportagem de conteúdo para administradores de plataformas online, auxiliando na identificação de materiais que possam violar termos de uso e direitos fundamentais de terceiros, assim como evitar que estes conteúdos falaciosos sejam amplamente compartilhados. ${ }^{258}$

Apenas com a união de esforços legislativos, judiciais e políticos será possível uma mudança do cenário brasileiro de aumento do hate speech, a longo prazo, o que proporcionaria maior efetividade também à liberdade de expressão e ao desenvolvimento de um debate livre e amplo, uma vez que as restrições ocorreriam apenas em caráter excepcional, delimitadas por lei adequada às recomendações de organismos internacionais, unicamente em caso de clara apologia ao ódio discriminatório apto a fomentar a segregação e violência. Em um cenário social enraizado de preconceito e da manipulação de poderes, como o brasileiro, a utilização da legislação deve ser realizada com cautela, somada às políticas públicas de tolerância, inclusão e promoção dos Direitos Humanos, para que ela não se reverta aos fins contrários de sua criação.

258 SOUZA, Carlos Affonso; PADRÃO, Vinícius. Quem lê tanta notícia (falsa)? Entendendo o combate contra as "fake news", 2017. Disponível em: <https://feed.itsrio.org/quem-1\%C3\%AAtanta-not $\% \mathrm{C} 3 \% \mathrm{ADcia}-$ falsa-entendendo-o-combate-contra-as-fake-news-70fa0db05aa5>. Acesso em 15 mai. 2018. 


\section{CONCLUSÃO}

Quando tratamos de liberdade de expressão, de maneira abstrata, é comum a ampla proteção a este direito, especialmente em razão de seu papel primordial para a legitimação democrática e desenvolvimento de uma comunidade plural e globalizada. Entretanto, esta larga defesa é posta em xeque quando nos deparamos com discursos odiosos, aptos a insultar, intimidar ou assediar certas pessoas ou grupo de pessoas em virtude de suas características essenciais, como raça, cor, etnicidade, nacionalidade, sexo ou religião, de forma a instigar violência, ódio ou discriminação contra tais esferas da sociedade. A problemática enfrentada pelo presente trabalho foi, portanto, tentar entender os limites da liberdade de expressão frente ao hate speech.

Diante desta questão, o capítulo 1 reuniu argumentos doutrinários a favor e contra a limitação do direito à livre expressão, com base em seus fundamentos e objetivos essenciais: (i) busca e descoberta da verdade; (ii) legitimação e manutenção do regime democrático; (iii) autorrealização individual; (iv) promoção da tolerância.

Dentre os argumentos utilizados pelos doutrinadores liberais, um dos principais é de que a proibição de discursos odiosos não é efetiva na redução das chances de resultados horríveis, pois há sempre a possibilidade de corrupção no uso de restrições. Para esta corrente, a ampla divulgação das mais variadas formas de discursos permitiria que a sociedade atuasse na escolha das ideias que deveriam prevalecer, com o consequente combate das que considera prejudiciais. Em oposição, defensores da restrição dos discursos levantam a tese de que o hate speech é responsável por negar a igualdade entre indivíduos, de forma a difundir a inferioridade, violência e discriminação, excluindo do debate público suas vítimas. 
Para a análise mais profunda desta questão, foi essencial o estudo de como os sistemas internacionais vêm tratando o assunto, conforme explorado no capítulo 2. Nota-se a adoção pelo direito norte-americano das ideias liberais de preferência prima facie da liberdade de expressão, onde o discurso de ódio sofre restrição mínima, apenas quando é acompanhado de violência real ou iminente. Em oposição, o posicionamento do Direito Alemão e Europeu, assim como de Organismos Internacionais de Direitos Humanos, é de que o hate speech deve ser combatido e devidamente punido, de acordo com as estipulações legais, sem que isso implique a eliminação do debate público e da liberdade de expressão - o ódio não deve ser tolerado, sob o risco de que se acabe com a própria tolerância.

O exame do cenário internacional foi essencial na análise das possibilidades de solução deste conflito para eventual aplicação no direito brasileiro. Como observado no capítulo 3, apesar de não possuir regulação específica a respeito do discurso de ódio, o Brasil segue, majoritariamente, a tendência do Direito Europeu em restringir essas expressões. No entanto, apesar desta orientação, os Tribunais não possuem padrão decisório de julgamento, em decorrência da grande abstração dos valores e princípios constitucionais em conflito, o que, somado a ausência de legislação específica, faz com que o conteúdo da Constituição Federal de 1988 seja definido casuisticamente, geralmente em prol do direito à igualdade e da dignidade da pessoa humana. Apesar dos propósitos elevados, deve-se ter cuidado para que estes não atuem asfixiando a liberdade de expressão, direito essencial inclusive para o exercício integral da igualdade e dignidade do ser humano.

A discussão a respeito de restrições ao discurso de ódio no Brasil agrava-se, ainda mais, pelo crescimento da polarização de ideias, onde aquele que pensa diferente é visto como inimigo a ser combatido, o que dificulta o debate equilibrado e racional entre visões opostas. Este cenário facilita também a divulgação de fake news, principalmente por meio de redes sociais, com a consequente criação de bolhas de informação 
unilaterais. Desta forma, verificamos a inadequação do país em relação aos standards internacionais, especialmente quanto às orientações da ONG Artigo 19 e do Rabat Plan of Action, além de escassa concretização de mecanismos tendentes a evitar esta divulgação, encontrados além do Direito, como o fact-checking e web-literacy.

Diante do contexto brasileiro, houve a constatação de que a restrição legal ao hate speech de fato implicaria a limitação à liberdade de expressão, mas de forma legítima, com base em legislação restrita a ser desenvolvida a partir dos referidos standards internacionais de direitos humanos, onde seria definida sua abrangência, conceitos e hipóteses, a partir do pressuposto de que limitações são válidas apenas na ausência de outra solução menos danosa. A positivação destas orientações facilitaria também a aplicação do entendimento legal de forma uniforme, proporcionando a sua utilização também em casos futuros e semelhantes, em prol da segurança jurídica dos julgados.

Além disso, observamos que o combate aos discursos de ódio, através de legislação de restrição, não deve tornar-se a defesa das concepções majoritárias ou de posições eticamente aceitas, para que não caiamos na ditadura do politicamente correto e para que não haja o surgimento do slippery slope e do chilling effect. A restrição não seria para impedir a expressão de ofensas e ideias que divergem da maioria, mas, somada à efetivação de políticas públicas educacionais e ações afirmativas em prol dos grupos estigmatizados da sociedade, seja forma de assegurar a dignidade e tratamento igualitário às minorias.

Portanto, o caminho defendido a ser utilizado pelo Brasil segue orientações do Direito Internacional dos Direitos Humanos, onde o discurso de ódio deve ser combatido e punido, não tolerado, em nome da livre expressão. Desta forma, as restrições devem ser legalmente definidas, restritivamente, com aplicação judiciária apenas nos casos prescritos em lei, além de somadas à atuação do Estado na efetivação de políticas públicas 
educacionais que promovam a tolerância, inclusão social e o amplo debate público. Há de se considerar também que este processo deve ser desenvolvido com a devida cautela e parcimônia, de maneira a não asfixiar a liberdade de expressão, elemento vital da democracia e da autossatisfação individual do ser humano, evitando a ditadura do politicamente correto e de concepções morais de determinado momento histórico. 


\section{REFERÊNCIAS BIBLIOGRÁFICAS}

ALEXANDER, Larry. Is there a Right of Freedom of Expression? New York: Cambridge University Press, 2005. 218p.

ALEXY, Robert. Balancing, Constitutional Review and Representation. International Journal of Constitutional Law, Vol. 3, Issue 4, 2005. p. 572581. Disponível em: <https://ssrn.com/abstract=914967>. Acesso em 18 mar. 2018.

ARISTÓTELES. Política. Tradução de Maria da Gama Kury. 3. ed. Brasília: Editora UnB, 1997.

Article 19. ARTIGO 19 repudia emenda que legaliza censura nas eleições brasileiras. 06 de outubro de 2017. Disponível em $<$ http://artigo19.org/blog/2017/10/06/artigo-19-repudia-emenda-quelegaliza-censura-nas-eleicoes-brasileiras/>. Acesso em 19 mar. 2018.

Article 19. 'Hate Speech' Explained: A Toolkit. 2015 Ed. Disponível em $<$ https://www.article19.org/data/files/medialibrary/38231/'Hate-Speech'Explained---A-Toolkit-\%282015-Edition\%29.pdf $>$. Acesso em 02 abr. 2018.

Article 19. The Camden Principles on Freedom of Expression and Equality. Disponível em <https://www.article19.org/data/files/pdfs/standards/thecamden-principles-on-freedom-of-expression-and-equality.pdf $>$. Último acesso em 21 mar. 2018.

AUSTIN, J. L. Quando dizer é fazer: palavras e ação. Porto Alegre: Artes Médicas, 1990. 136p.

BAKER, C. Edwin. Hate Speech. Faculty Scholarship. Paper 198, 2008.

BALEM, Isadora Forgiarini. O impacto das Fakenews e o Fomento dos Discursos de Ódio na Sociedade em Rede: a Contribuição da Liberdade de Expressão na Consolidação Democrática. Santa Maria, 2017. Disponível em $<$ http://coral.ufsm.br/congressodireito/anais/2017/1-12.pdf $>$. Acesso em 02 abr. 2018. 
BARROSO, Luís Roberto. Curso de Direito Constitucional Contemporâneo: os conceitos fundamentais e a construção do novo modelo. $4^{\mathrm{a}}$ ed. São Paulo: Saraiva, 2013. 511p.

BBC. Facebook to Tackle Fake News With Educational Campaign, 2017. Disponível em $<$ http://www.bbc.com/news/technology-39517033>. Acesso em 15 mai. 2018.

BBC. Google News Lauches Fact Check Label, 2016. Disponível em $<$ http://www.bbc.com/news/technology-37657524>. Acesso em 25 mai. 2018.

BOLLINGER, Leo C. The Tolerant Society: Freedom of Expression and Extremist Speech in America. New York: Oxford University Press, 1986. 320 p.

BRUGGER, Winfried. Proibição ou proteção do discurso do ódio?: algumas observações sobre o direito alemão e o americano. Brasília: Instituto Brasiliense de Direito Público, ano 4, janeiro-março, 2007. p. 117136.

BRUGGER, Winfried. The Treatment of Hate Speech in German Constitutional Law. Charlottesville: German Law Journal, Vol. 4, $\mathrm{n}^{\mathrm{o}}$ 1, 2003.

BUTLER, Judith. Excitable Speech: A Politics of the Performative. New York: Routledge, 1997. 185p.

CHEQUER, Cláudio. A Liberdade de Expressão como Direito Fundamental Preferencial Prima Facie: (análise crítica e proposta de revisão ao padrão jurisprudencial brasileiro). Rio de Janeiro: Lumen Juris, 2011.353p.

Comissão Interamericana De Direitos Humanos. Informe Anual 2012. Informe de la Relatóría para la Libertad de Expresión. Disponível em: $<$ http://www.oas.org/es/cidh/expresion/docs/informes/anuales/informe\%20a nual\%202012.pdf>. Acesso em 17 mar. 2018.

Comissão Interamericana De Direitos Humanos. Marco jurídico interamericano sobre o direito à liberdade de expressão. Relatoria Especial para a Liberdade de Expressão, 2014. Disponível em: 
$<$ https://www.oas.org/pt/cidh/expressao/docs/publicaciones/20140519\%20$\% 20$ PORT\%20Unesco\%20-

$\% 20$ Marco\%20Juridico\%20Interamericano\%20sobre\%20el\%20Derecho\%2 0a\%201a\%20Libertad\%20de\%20Expresion\%20adjust.pdf>. Acesso em 17 mar. 2018.

Comitê de Ministros do Conselho da Europa. Recomendação (97) 20. Disponível em $<$ https://rm.coe.int/1680505d5b $>$. Acesso em 19 mar. 2018.

Correio do Povo. Especialistas analisam ódio em meio à polarização política. 04 de abril de 2016. Disponível em $<$ http://www.correiodopovo.com.br/Noticias/Politica/2016/4/584517/Especi alistas-analisam-odio-em-meio-a-polarizacao-politica $>$. Acesso em 29 mar. 2018.

DELMAS-MARTY, Mireille. Por um direito comum. São Paulo: Martins Fontes, 2004. 310p.

Deutsche Welle. Alemã de 88 anos é condenada por negar Holocausto. Disponível em: <http:/www.dw.com/pt-br/alem\%C3\%A3-de-88-anos$\%$ C3\%A9-condenada-por-negar-holocausto/a-40974633>. Acesso em 19 mar. 2018.

Deutsche Welle. Alemã de 89 anos começa a cumprir pena por negar Holocausto. Disponível em: <http://www.dw.com/pt-br/alem\%C3\%A3-de89-anos-come $\% \mathrm{C} 3 \% \mathrm{~A} 7 \mathrm{a}$-a-cumprir-pena-por-negar-holocausto/a43692520>. Acesso em 21 mai. 2018.

Deutsche Welle. Lei contra discurso de ódio na internet entra em vigor na Alemanha. Disponível em: $<\mathrm{http} / / \mathrm{m} . \mathrm{dw} . c o m / \mathrm{pt}-\mathrm{br} / \mathrm{lei}$-contra-discurso-de\%C3\%B3dio-na-internet-entra-em-vigor-na-alemanha/a-41996447>. Acesso em 19 mar. 2018.

DIAS, Julio César Tavares; CAMPOS, Zuleica Dantas Pereira. O Discurso de Intolerância da Igreja Universal do Reino de Deus: Uma Análise do Livro "Orixás, Caboclos e Guias". Goiânia: Fragmentos de Cultura, n. 4, $2012 . \quad$ Disponível em: $<$ http://seer.ucg.br/index.php/fragmentos/article/viewFile/2551/1584>. Acesso em 27 mar. 2018. 
DWORKIN, Ronald. Foreword to Extreme Speech and Democracy. In.: HARE, Ivan; WEINSTEIN, James (editors). Extreme Speech and Democracy. New York: Oxford University Press, 2009. p. v-ix;

DWORKIN, Ronald. $O$ Direito da Liberdade: A Leitura Moral da Constituição Norte-Americana. São Paulo: Martins Fontes Editora, 2006. $572 p$.

Estadão. Brasil é terreno fértil à desinformação, dizem especialistas. Disponível em $<$ http://politica.estadao.com.br/noticias/geral,brasil-eterreno-fertil-a-desinformacao-dizem-especialistas,70002213869>. Acesso em 02 abr. 2018.

FISS, Owen. A Ironia da Liberdade de Expressão: Estado, Regulação e Diversidade na Esfera Pública. Rio de Janeiro: Renovar, 2005. 146p.

FOLLON Jr., Richard H.. The Dynamic Constitution: An Introduction to American Constitutional Law and Practice. $2^{\mathrm{a}}$ ed. Nova York: Cambridge University Press, 2013. 434p.

G1. Jovem é condenada por mensagem contra nordestinos no Twitter. São Paulo, 15 de maio de 2012. Disponível em <http:/g1.globo.com/saopaulo/noticia/2012/05/condenada-estudante-que-publicou-mensagemcontra-nordestinos-em-sp.html>. Acesso em 28 mar. 2018.

GRAVES, Lucas; NYHAN, Brendan; REIFLER, Jason. Understanding Innovations in Journalistic Practice: A Field Experiment Examining Motivations for Fact-Checking. Volume 66, Issue 1. Oxford: Oxford Academic, Journal of Communication, 2016. p. 102-138.

HART, James W. The European Human Rights System. Cincinnati: Law Library of University of Cincinnati College of Law Scholarship and Publications, Paper 533, 2010. p. 533-559.

International Justice Resource Center. Preventing and Remedying Human Rights Violations through the International Framework: Advocacy before the Inter-American System - Manual for Attorneys and Advocates. Disponível em <http://ijrcenter.org/wp-content/uploads/2009/12/Manualfor-Attorneys-and-Advocates.pdf $>$. Acesso e, 17 mar. 2018. 
JÚNIOR, Owvaldo Giacoia. E se o erro e a fabulação do engano se revelarem tão essenciais quanto à verdade? Disponível em $<$ http://www1.folha.uol.com.br/ilustrissima/2017/02/1859994e-se-o-erro-afabulacao-o-engano-revelarem-se-tao-essenciais-quanto-a-verdade.shtml $>$. Acesso em 02 abr. 2018.

KOMMERS, Donald P.; MILLER, Russel A. The Constitutional Jurisprudence of the Federal Republic of Germany. $2^{\mathrm{a}}$ ed.. Durham: Duke University Press, 1997. 904p.

LEITE, Fábio Carvalho. Liberdade de Expressão e Direitos da Personalidade: (Novos) Fundamentos para a posição preferencial da Liberdade de Expressão nos conflitos com o direito à honra e à imagem, 2015.

LEWIS, Anthony. Liberdade Para as Ideias que Odiamos: Uma Biografia da Primeira Emenda à Constituição Americana. São Paulo: Aracati, 2011. 248p.

LODE, Eric. Slippery Slope Arguments and Legal Reasoning. California Law: Review, vol. 87, issue 6, 1999. Disponível em $<$ https://scholarship.law.berkeley.edu/cgi/viewcontent.cgi?article $=1535 \&$ co ntext=californialawreview $>$. Acesso em 02 abr. 2018.

MACKINNON, Catherine. Are women human? And other international dialogues. Cambridge: Harvard University Press, 2007. 432p.

MACKINNON, Catharine. Only Words. 3th edition. Cambridge: Harvard University Press, 1996. 161p.

MAGRANI, Eduardo. Democracia conectada: a internet como ferramenta de engajamento político-democrático. Juruá: Rio de Janeiro, 2014. 222p. Disponível em: $<$ http://bibliotecadigital.fgv.br/dspace/handle/10438/14106>. Acesso em 10 mai. 2018.

MAHONEY, Kathleen. Hate Vilification Legislation And Freedom Of Expression: Where Is The Balance? Disponível em: $<$ http://www.austlii.edu.au/au/journals/AUJlHRights/1994/21.html $>$. Acesso em 17 out. 2017. 
MEYER-PFLUG, Samantha Ribeiro. Liberdade de expressão e discurso do ódio. São Paulo: RT, 2009. 271p.

MILL, John Stuart. On Liberty (1859). Kitchener: Batoche Books, 2001. 109 p.

NEXO. Quando é justificável proibir um discurso, segundo esta ONG. 28 de agosto de 2017.2 Disponível em $<$ https://www.nexojornal.com.br/entrevista/2017/08/22/Quando-\%C3\%A9justific\% $\% 3 \%$ A1 vel-proibir-um-discurso-segundo-esta-ONG $>$. Acesso em 02 abr. 2018.

O Globo. Brasil cultiva discurso de ódio nas redes sociais, mostra pesquisa. 03 de agosto de 2016. Disponível em $<$ https://oglobo.globo.com/sociedade/brasil-cultiva-discurso-de-odio-nasredes-sociais-mostra-pesquisa-19841017>. Acesso em 29 mar. 2018.

O Globo. EUA: Carro avança contra protesto antirracismo e deixa um morto. 12 de agosto de 2017. Disponível em $<$ https://oglobo.globo.com/mundo/eua-carro-avanca-contra-protestoantirracismo-deixa-um-morto-1-21699532>. Acesso em 19 abr. 2018.

O Globo. Entidades ligadas à imprensa criticam emenda que permite censura eleitoral na internet. 05 de outubro de 2017. Disponível em $<$ https://oglobo.globo.com/brasil/entidades-ligadas-imprensa-criticamemenda-que-permite-censura-eleitoral-na-internet-21914725>. Acesso em 19 mar. 2018.

O Globo. Juíza suspende venda de livro do bispo Edir Macedo. Salvador, 10 de novembro de 2005. Disponível em $<$ http://www1.folha.uol.com.br/folha/cotidiano/ult95u115122.shtml $>$. Acesso em 27 mar. 2018.

O Globo. Temer sanciona reforma política com veto a censura na internet. 06 de outubro de 2017.2 Disponível em $<$ https://oglobo.globo.com/brasil/temer-sanciona-reforma-politica-comveto-censura-na-internet-21919897>. Acesso em 19 mar. 2018.

OLOF, Sundin. Negotiations on information-seeking expertise: A study of web-based tutorials for information literacy. Lund: Journal of Documentation, 2008. 44p. 
OMMATI, José Emílio Medauar. Liberdade de Expressão e Discurso de ódio na Constituição de 1988. $3^{\mathrm{a}}$ Ed. Rio de Janeiro: Lumen Juris Direito, 2016. 226p.

Oxford Human Rights Hub (OHRH). Comparative Hate Speech Law: Annexure. Research prepared for the Legal Resources Centre. Oxford Pro Bono Publico, 2012. Disponível em: http://ohrh.law.ox.ac.uk/wordpress/wpcontent/uploads/2014/05/2012-RCHate-Speech-Annexure-2.pdf>. Acesso em 15 out. 2017.

Office of the High Commissioner for Human Rights (OHCR). Rabat Plan of

Action on the prohibition of advocacy of national, racial or religious hatred that constitutes incitement to discrimination, hostility or violence. Morocco, $2012 . \quad$ Disponível em: $<$ http://www.ohchr.org/Documents/Issues/Opinion/SeminarRabat/Rabat_dr aft_outcome.pdf $>$. Acesso em 21 mar. 2018.

POTIGAR, Alex Lobato. Igualdade e Liberdade: a luta pelo reconhecimento da igualdade como direito à diferença no Discurso do Ódio. Brasília. 2009. Dissertação em Pós-Graduação em Direito - Universidade de Brasília.

R7. Ódio contra eleitores nordestinos deve passar logo. Rio de Janeiro, 28 de outubro de 2018. Disponível em <https://noticias.r7.com/eleicoes2014/odio-contra-eleitores-nordestinos-deve-passar-logo-28102014>. Acesso em 28 mar. 2018.

Redação final do Projeto de Lei $\mathrm{n}^{\mathrm{o}}$ 8.612-B de 2017. Disponível em $<$ https://www.poder360.com.br/wp-content/uploads/2017/10/5out-redacaofinal-PL-8612-2017.pdf>. Aceso em 29 mar. 2018.

Reuters. Justiça proíbe Viradouro de levar carro do Holocausto à Sapucaí. Rio de Janeiro, 31 de janeiro de 2008. Disponível em $<$ https://br.reuters.com/article/entertainmentNews/idBRN31572095200801 31>. Aceso em 27 mar. 2018.

ROSENFELD, Michel. Hate Speech in Constitutional Jurisprudence: A Comparative Analysis. Cardozo Law Review. New York: Working Paper Series No. 41, 2001. Disponível em: 
$<$ http://papers.ssrn.com/sol3/papers.cfm?abstract_id=265939>. Acesso em 17 out. 2018.

SARMENTO, Daniel. A Liberdade de Expressão e o Problema do Hate Speech. Rio de Janeiro, 2006. Disponível em $<$ http://www.dsarmento.adv.br/content/3-publicacoes/18-a-liberdade-deexpressao-e-o-problema-do-hate-speech/a-liberdade-de-expressao-e-oproblema-do-hate-speech-daniel-sarmento.pdf $>$. Último acesso em $02 \mathrm{abr}$. 2018 .

SARMENTO, Daniel. Livres e Iguais. Rio de Janeiro: Lúmen Júris, 2006. 308 p.

SARTONI, Giovanni. A Teoria da Democracia Revisada: volume I - o debate contemporâneo. Tradução de Dinah de Abreu Azevedo. São Paulo: Editora Átila, 1994. 336p.

SCHAUER, Frederick. Thinking Like a Lawyer: A New Introduction to legal

Reasoning. London: Harvard University Press, 2009. 256p.

SHU Kai et al.. Fake News Detection on Social Media: A Data Mining Perspective. 2017. Disponível em <https://arxiv.org/pdf/1708.01967.pdf $>$. Acesso em 10 mai. 2018.

SIGAL, Ivan. Fake News and Fake Solutions. How Do We Build a Civics of Trust?, 2017. Disponível em <https://globalvoices.org/2017/03/17/fakenews-and-fake-solutions-how-do-we-build-a-civics-of-trust/>. Acesso em 15 mai. 2018.

SILVA, Priscilla Regina da. Os Limites Sagrados da Liberdade: uma análise do discurso de ódio contrarreligioso. Rio de Janeiro. Março de 2017. 205p. Dissertação em Pós-Graduação em Direito - PUC-Rio.

SODRÉ, Lu. A intolerância sai do armário, chega às ruas e se propaga na internet. São Paulo: Entreteses (Revista da Universidade federal de São Paulo - UNIFESP), Edição de 2017. Disponível em: $<$ http://www.unifesp.br/reitoria/dci/entreteses/item/2584-a-intolerancia-saido-armario-chega-as-ruas-e-se-propaga-na-internet>. Acesso em 19 mar. 2018. 
SOUZA, Carlos Affonso; PADRÃO, Vinícius. Quem lê tanta notícia (falsa)? Entendendo o combate contra as "fake news", 2017. Disponível em: $<\mathrm{https}$ ://feed.itsrio.org/quem-1\%C3\%AA-tanta-not\%C3\%ADcia-falsaentendendo-o-combate-contra-as-fake-news-70fa0db05aa5>. Acesso em 15 mai. 2018.

SUNSTEIN, Cass. R. Beyond Judicial Minimalism. Chicago: University of Chicago Law School, 43 Tulsa Law Review 825, 2007.

SUNSTEIN, Cass. Republic.com 2.0. Nova Jersey: Princeton University Press, 2007. 272p.

Terra. Nordestinos são hostilizados após vitória de Dilma Roussef. Disponível em <https://www.terra.com.br/noticias/eleicoes/nordestinossao-hostilizados-apos-vitoria-de-dilmarousseff,aa13fc86bd059410VgnVCM5000009ccceb0aRCRD.html>. Acesso em 28 mar. 2018.

THWEAT, Elizabeth. Bibliography of hate studies materials. Spokane, WA: Journal of hate studies, vs.1, 2001/2002. p. 167-239.

TOLLER, Fernando M. O formalismo na liberdade de expressão: discussão da diferenciação entre restrições prévias e responsabilidades ulteriores. Tradução de Frederico Bonaldo. São Paulo: Saraiva, 2010.

UOL (A Tarde). Justiça libera venda de livro de Edir Macedo. Salvador, 26 de setembro de 2006.2 Disponível em $<$ http://atarde.uol.com.br/bahia/salvador/noticias/1266396-justica-liberavenda-de-livro-de-edir-macedo>. Acesso em 09 mai. 2018.

VANEIGEM, Raoul. Nada é sagrado, tudo pode ser dito: reflexões sobre a liberdade de expressão. São Paulo: Parábola Editorial, 2004. 100p.

WALDRON, Jeremy. Precommitment and Disagreement. In: ALEXANDER, Larry (editor). Constitutionalism: Philosophical Foundations. Cambridge: Cambridge University Press, 1998. 319p.

WALDRON, Jeremy. The Harm in Hate Speech. Cambridge: Harvard University Press, 2012. 304p. 
WEINSTEIN, James. An Overview of American Free Speech Doctrine and its Application to Extreme Speech. In: HARE, Ivan; WEINSTEIN, James (editors). Extreme Speech and Democracy. New York: Oxford University Press, 2009. p. 81-91.

WEINSTEIN, James. Extreme Speech, Public Order, and Democracy: Lessons from the Masses. In: HARE, Ivan; WEINSTEIN, James (editors). Extreme Speech and Democracy. New York: Oxford University Press, 2009. p. 23-61. 


\section{Listagem de casos}

6 Câmara Cível do TJRJ. Apelação Cível no 0115411-06.2011.8.19.0001. Rel. Inês da Trindade Chaves de Melo. Rio de Janeiro, 08 de novembro de $2017 . \quad$ Disponível em $<$ http://www1.tjrj.jus.br/gedcacheweb/default.aspx?UZIP=1\&GEDID=0004 FF763E09038C86205C99064368E3D1E1C5072018010D>. Acesso em 28 mar. 2018.

$15^{\mathrm{a}}$ Vara Cível do TJRJ. Processo $\mathrm{n}^{\mathrm{o}}$ 0070926-71.2018.8.19.0001. Juiz Jorge Jansen Couñago Novelle, 28 de março de 2018.

$26^{\mathrm{a}}$ Vara Federal da Seção Judiciária do Rio de Janeiro. Ação Civil Pública $\mathrm{n}^{\mathrm{o}}$ 0101298-70.2017.4.02.5101. Juíza federal Frana Elizabeth Mendes. 25 de setembro de 2017.

$33^{\mathrm{a}}$ Vara Cível do Rio de Janeiro, Processo ${ }^{\circ}$ 0024517-86.2008.8.19.0001, Juíza Juliana Kalichszteim, Rio de Janeiro, 2008.

47 Vara Cível do TJRJ. Processo no 0066013-46.2018.8.19.0001. Juíza Marcia Correia Hollanda, 22 de março de 2018.

Auschwitz lie. [BVerfGE] 90, 241-255. Disponível em: $<$ https://law.utexas.edu/transnational/foreign-law-

translations/german/case.php?id=621>. Acesso em 28 mar. 2018.

Beauharnais Vs. Illinois 343 US 250 (1952). Disponível em $<$ https://www.oyez.org/cases/1940-1955/343us250>. Acesso em 14 mar. 2018.

Brandenburg Vs. Ohio 395 U.S. 444 (1969). Disponível em: $<$ https:/www.oyez.org/cases/1968/492>. Acesso em 15 mar. 2018.

Garaudy vs. France. CEDH, nº 65831/01. 2003.

Jersild Vs. Denmark. ECHR, n ${ }^{\text {o }}$ 15890/89.1994. Disponível em $<$ https://globalfreedomofexpression.columbia.edu/cases/jersild-vdenmark/>. Acesso em 19 mar. 2018.

Lehideux and Isorni Vs. France. ECHR, no 24662/94.1998. Disponível em $<$ https://www.legal-tools.org/doc/2fed5c/pdf/>. Acesso em 19 mar. 2018. 
National Socialist Party of America v. Village of Skokie 432 U.S. 43 (1977). Disponível em: <https://supreme.justia.com/cases/federal/us/432/43/>. Acesso em 16 mar. 2018.

Otto-Preminger Institut Vs. Austria. ECHR, $\mathrm{n}^{\circ}$ 13470/87. Disponível em $<$ https://globalfreedomofexpression.columbia.edu/cases/otto-premingerinstitut-v-austria/>. Acesso em 20 mar. 2018.

R.A.V. VS. St. Paul 505 U.S. 377 (1992). Disponível em $<$ https://supreme.justia.com/cases/federal/us/505/377/case.html $>$. Acesso em 16 mar. 2018.

Snyder Vs. Phelps 562 U.S. 443 (2011). Disponível em $<$ https://www.oyez.org/cases/2010/09-751>. Acesso em 16 mar. 2018.

STF, HC n ${ }^{\circ} 82.424-2 / \mathrm{RS}$, Rel. Ministro Moreira Alves, Brasília, 17 set. $2003 . \quad$ Disponível em $<$ http://redir.stf.jus.br/paginadorpub/paginador.jsp?docTP $=\mathrm{AC} \&$ docID $=790$ 52>. Acesso em 27 mar. 2018.

Strauß Caricature Case. [BVerfGE] 75, 369 (1987). Disponível em: $<$ https://law.utexas.edu/transnational/foreign-lawtranslations/german/case.php?id=634>. Acesso em 18 mar. 2018.

TJSP, Apelação Criminal n 238.705.3/0, Rel. Geraldo Xavier, São Paulo, 10 nov. 1999.

Tucholsky Case. [BVerfGE] 93, 266. Disponível em: $<$ https://law.utexas.edu/transnational/foreign-lawtranslations/german/case.php?id=620>. Acesso em 18 mar. 2018.

Virginia Vs. Black et. al.. Disponível em: $<$ https://www.oyez.org/cases/2002/01-1107>. Acesso em 16 mar. 2018.

Vogt Vs. Germany. ECHR (Plenary), no 17851/91.1992. Disponível em $<$ http://freecases.eu/Doc/CourtAct/4540252>. Acesso em 19 mar. 2018. 